\title{
The Nation of Vaccine Development Influences Vaccine Acceptance ${ }^{*}$
}

\author{
Joan Barceló $^{\dagger} \quad$ Greg Chih-Hsin Sheen ${ }^{\ddagger} \quad$ Hans H. Tung ${ }^{\S}$ \\ Wen-Chin $\mathrm{Wu}^{\mathbb{I}}$
}

September 1, 2021

\begin{abstract}
What types of vaccines are citizens most likely to accept? We administered a conjoint experiment requesting 15,000 adult citizens across 14 countries from around the world to assess 450,000 profiles of vaccines that randomly varied on seven attributes. Beyond vaccine fundamentals such as efficacy rate, number of doses, and duration of the protection, we find that citizens systematically favor vaccines developed and produced in their own country of residence. These results indicate that a sociological form of vaccine nationalism shapes vaccine acceptance. The extent of preference in favor of vaccines developed and produced within the national borders is particularly large among citizens who identify more strongly with their nation, suggesting nationalism plays a role in explaining the bias in favor of vaccines developed and produced locally. This public opinion bias on vaccine preferences has significant theoretical and practical implications.
\end{abstract}

${ }^{*}$ Corresponding author. Email: joan.barcelo@nyu.edu. Complete replication files will be provided upon publication.

${ }^{\dagger}$ Division of Social Science, New York University Abu Dhabi.

$\ddagger$ Division of Social Science, New York University Abu Dhabi and Department of Political Science, National Cheng Kung University.

$\S$ Department of Political Science. National Taiwan University.

II Institute of Political Science, Academia Sinica, Taiwan. 
The SARS-CoV-2 (also known as COVID-19) has quickly risen to become one of the deadliest pandemics in history producing nearly 4 million confirmed deaths worldwide $(1,2)$. In just about eighteen months since the beginning of the pandemic, seven vaccines have been approved by the World Health Organization, 16 vaccines have received emergency-use authorization by at least one country in the world, 102 vaccines are in clinical trials; and 185 in pre-clinical phase trials (3). At the time of writing, several efficacious and safe vaccines have been inoculated in over 2.4 billion citizens across the globe (4).

While vaccines bring hope for an end to the pandemic, public hesitancy to accept vaccination remains a global challenge. The Imperial College London YouGov Covid 19 Behaviour Tracker indicates that about $64 \%$ of the study's sample, which includes 17 countries, would take a vaccine if it was offered to them (5). Similarly, a recent survey of 13,426 people in 19 countries shows that $71.5 \%$ of respondents would take a vaccine if offered (6). Adding 15 additional samples covering countries at varying levels of development, a recent investigation has also revealed an average acceptance rate fell below $70 \%$ across all countries (7).

However, these figures mask significant heterogeneity. Vaccine acceptance greatly varies from country to country from widespread acceptance in some countries such as Nepal (97\%), China (88.6\%) and Brazil (85.4\%), to significant vaccine hesitancy in countries such as Burkina Faso (67\%), France (59\%) and Russia (55\%) $(6,7)$. Using our own data, Figure 1 also reveals enormous variation in the willingness to accept COVID19 vaccines across countries. Overall, the levels of COVID-19 vaccine acceptance are insufficient to meet the requirements for herd immunity in many countries as important subgroups self-exclude from the vaccine rollout.

Meanwhile, the growth of vaccine hesitancy has long been considered a global concern (8) and is currently deemed as one of the major global health threats (9). Substantial 
Fig. 1 Willingness to accept COVID-19 vaccines across countries. The online Appendix 1.4 describes how the variable willingness to take COVID-19 vaccines was coded.

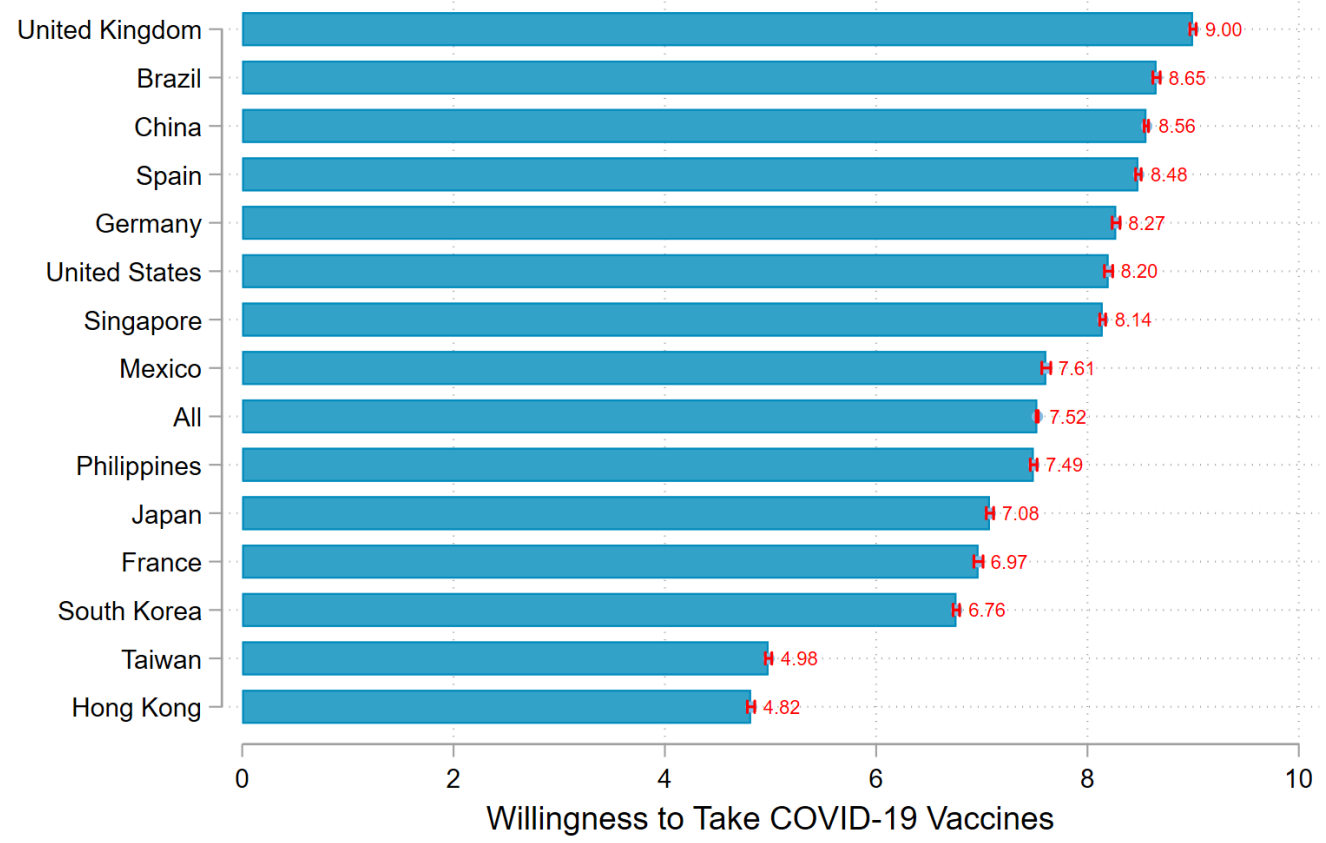

literature has identified the sociological correlates of vaccine acceptance in general (1012), and a few studies have already focused on the COVID-19 vaccine in particular (13, 14). This latter set of studies has provided significant findings into the sociological determinants of vaccine acceptance, ranging from demographics and perceived efficacy (13) to ideological and religious beliefs (14). However, less attention has been paid to the country of origin of the vaccine.

In the last few months, the concept of vaccine nationalism's politics has risen to public debate (15). The discussion has thus far been dominated by its policy dimension, defining different governments' strategies to become the first to inoculate their citizens. The nationalistic race for vaccination has slowed down vaccine rollout and impacted global vaccine equity with significant implications for global health (16). Academics and pundits have paid less attention to the sociological dimension of vaccine nationalism whereby citizens' identification with their nation and support for its interests may lead 
them to prefer vaccines developed and produced within their national borders, to the exclusion and / or detriment of the vaccines from other nations. We study here how the variable of the nation of vaccine development may influence vaccine acceptance.

Previous studies on the determinants of vaccine acceptance have largely neglected the role of country of origin $(13,14)$, restricted to single-country studies $(13,17-19)$, and/or drawn observational evidence by using direct survey questions about vaccine acceptance in general (14) without employing experimental methods to distinguish between different types of vaccines. Consequently, we lack a complete examination that captures which particular types of COVID-19 vaccines citizens are more willing to accept, and a specific assessment of how the nation of vaccine development biases vaccine acceptance.

To provide such an examination, we designed a conjoint experiment and embedded it in a large-scale online public opinion survey that we distributed in 14 countries around the world (20). Conjoint methods evaluate the association of vaccine attributes with the decision to choose one of a selection of COVID-19 vaccines. This experimental design has been widely employed in marketing research to examine consumer preferences (21) and has been increasingly used in the social sciences $(22,23)$ and medical research $(24)$. This design outperforms other conjoint designs and vignettes in minimizing social desirability bias and predicting real-world behavior (25).

The experimental task presents respondents with a pair of hypothetical vaccine profiles through a random combination of vaccine attributes a citizen may encounter clinically. It then asks them to make a forced binary choice after considering the trade-offs among the vaccine characteristics. We employed a conjoint experiment asking 15,648 adult individuals to assess 469,440 vaccine profiles that randomly varied on 7 attributes: the vaccine country of development, the vaccine country of production, efficacy rate, number of doses, vaccine technology, duration of the protection, and public endorse- 
ments. By estimating the Average Marginal Component-specific Effects (AMCE), this conjoint design allows us to examine how the nation of vaccine development influences respondents' vaccine acceptance vis-à-vis variation in the expected benefits and costs of coronavirus vaccination, as well as how this willingness varies depending on respondents' pre-existing nationalistic feelings.

In the present work, we find that a sociological form of vaccine nationalism strongly shapes vaccine acceptance. Besides the role of vaccine fundamentals such as efficacy rate, number of doses, and duration of the protection, we causally identify that citizens are systematically more willing to accept vaccines developed and produced in their own country of residence. When analyzing this country-of-origin bias across Nationalism, we find that individuals who identify more strongly with their nation are more likely to favor vaccines developed and produced within the national borders compared to individuals who feel less attached to their own country. These findings suggest that nationalism plays a major role in explaining the preference for vaccines developed and produced nationally.

\section{Results}

Figure 2 shows the effects of vaccine characteristics on the overall probability of accepting the vaccine across all respondents (model in table S4). Our experimental results reveal that the specific attributes of a vaccine importantly shape willingness to accept it. Beyond vaccine fundamentals such as duration of protection, vaccine technology, efficacy rates, and the number of doses, we find that a country of vaccine origin significantly affects citizens' willingness to accept a vaccine. Compared to the vaccines developed in their own country, respondents are 8.4 percentage points less likely to accept a vaccine when it is developed in a foreign country $(\mathrm{P}<0.001)$ and 4.5 percentage points less likely to accept a vaccine when it is produced in a foreign country $(\mathrm{P}<0.001)(26)$. The difference 
in the aggregate effects is statistically significant at the $\mathrm{P}<0.001$ level, suggesting that the national bias is stronger with regards to the country of vaccine development rather than the country of vaccine production.

Figure 2 also highlights heterogeneity across vaccines' country of origin. While the negative effect is present across all the countries included in our study, vaccines developed in China and Russia stand out for being less favored by 14 percentage points $(\mathrm{P}<0.001)$ and 13 percentage points $(\mathrm{P}<0.001)$ respectively when compared to locally developed vaccines. Despite a smaller effect in magnitude, China and Russia are again the least favored producers and dampened the willingness to accept a vaccine by 7 percentage points and 4 percentage points $(P<0.001)$ respectively. The bias against foreign vaccines extends to two of the most technologically advanced countries in the development of vaccines: Germany and the United States. Respondents are more likely to prefer homegrown vaccines than vaccines developed in Germany $(P<0.001)$ or the United States $(P<0.001)$ by 5 percentage points. In contrast, respondents show a small bias against vaccines manufactured in Germany and the United States with a decline in the acceptance of the vaccine by only 1 and 2 percentage points respectively. We stratify this analysis by citizens' gender (figs. S5 and tables S9 and S10), and age groups (fig. S6 and tables S11 and S16). Overall, we find that the effects of vaccines' country of development and production remain broadly similar across the different subgroups, which suggests that there is a general consensus among women and men, and young and old on which vaccines are preferred.

Despite differences in effect magnitude, Figure 3 shows that the patterns identified from the pooled sample largely remain when we break down the data to 14 individual countries. Respondents systematically report lower preferences for vaccines developed in any of the foreign countries in the study with the exception of the samples from Mexico, Hong Kong, and the Philippines. In the Hong Kong and the Filipino samples, people are slightly in favor of the American and the German vaccines compared to sim- 
Fig. 2 Effects of vaccine attributes on the probability of accepting the vaccine. Pooled sample across 14 countries.

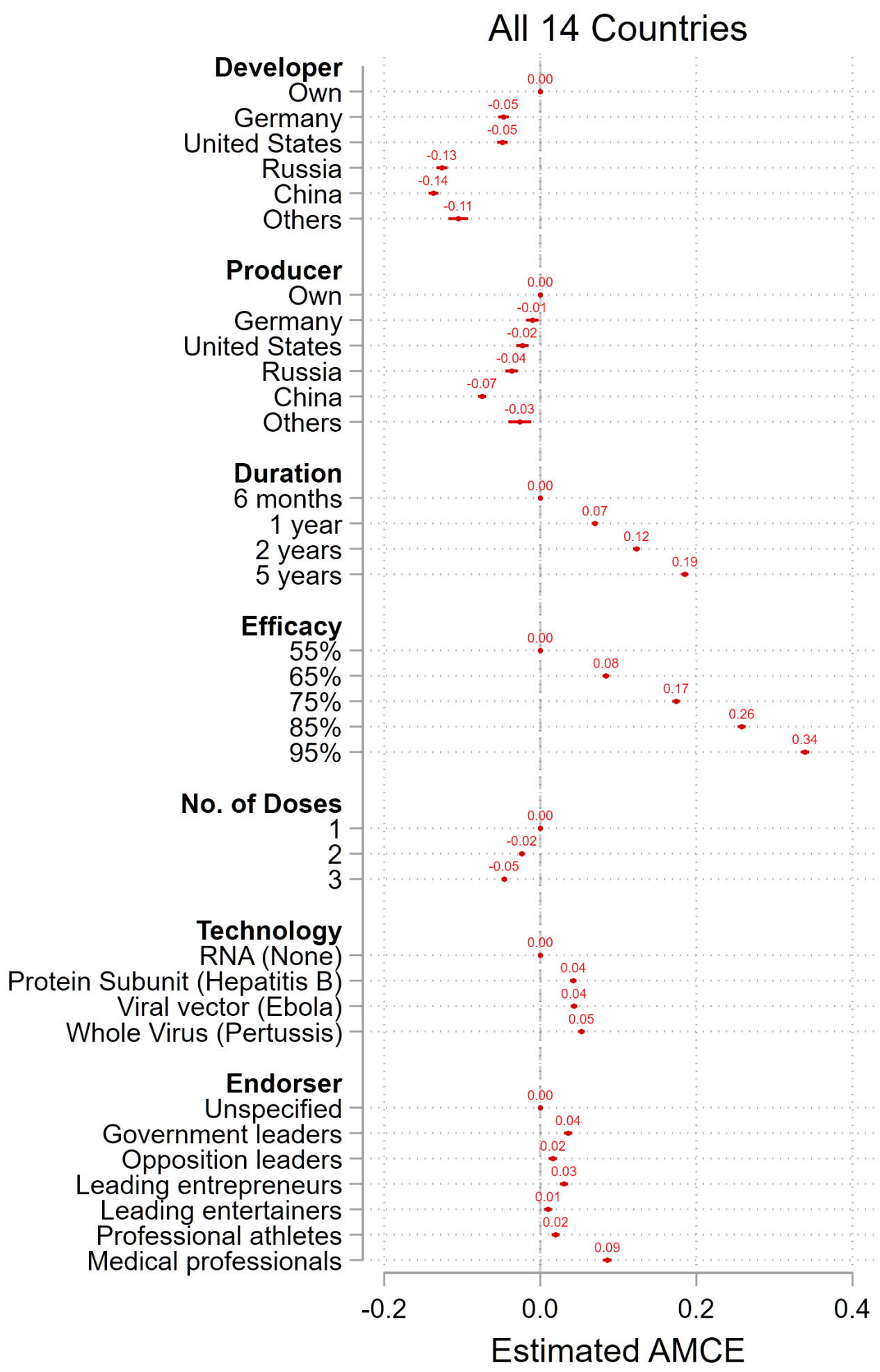


ilar vaccines developed locally, yet both samples still reveal a bias against the vaccines of Chinese origin - and of that Russian origin in the Hong Kong sample. In the Mexican sample, people showed no significant preference for the locally developed vaccines except for a systematic bias against Chinese vaccines. What is worth mentioning is that the effect of country of origin was even substantially more pronounced in the Asian samples. For example, compared to homegrown vaccines, vaccines developed in China induced more than 34 percentage points of disapproval in Japan, 27 percentage points in South Korea, and 21 percentage points in Taiwan. Regarding the vaccine production, however, the results are similar between the pooled and the country-specific samples, generally revealing a systematic and significant pattern against vaccines manufactured in Russia and China and negligible effects against those produced in Germany and the United States across most individual country samples.

Do the country-of-origin estimated effects vary across respondents' strength of national identification? If nationalism drives preference for vaccines, we might expect the nationalistic subgroup of respondents to rely more on the fact that a vaccine is developed domestically - rather than abroad - compared to less nationalistic respondents. Figure 4 reports the pooled regression estimates for those respondents with Low $\mathrm{Na}$ tionalism (25th percentile or lower of the within-country distribution in the Nationalism score) and those with High Nationalism (75th percentile or higher of the within-country distribution in the Nationalism score) (models in table S5). Figure 4 shows that the preference for the vaccine developed by one's own nation compared to all the others is negative for both high and low nationalistic subgroups, yet the magnitude strongly varies by respondents' nationalism. While respondents who identify more strongly with their nation are about 10 percentage points more likely to choose a vaccine developed in their own country (compared to a similar vaccine developed abroad $(\mathrm{P}<0.001)$ ), the differential preference reduces to 6 percentage points among low nationalistic respondents $(\mathrm{P}<0.001)(27)$. 
Fig. 3 Effects of vaccine attributes on the probability of accepting the vaccine by country subgroup.

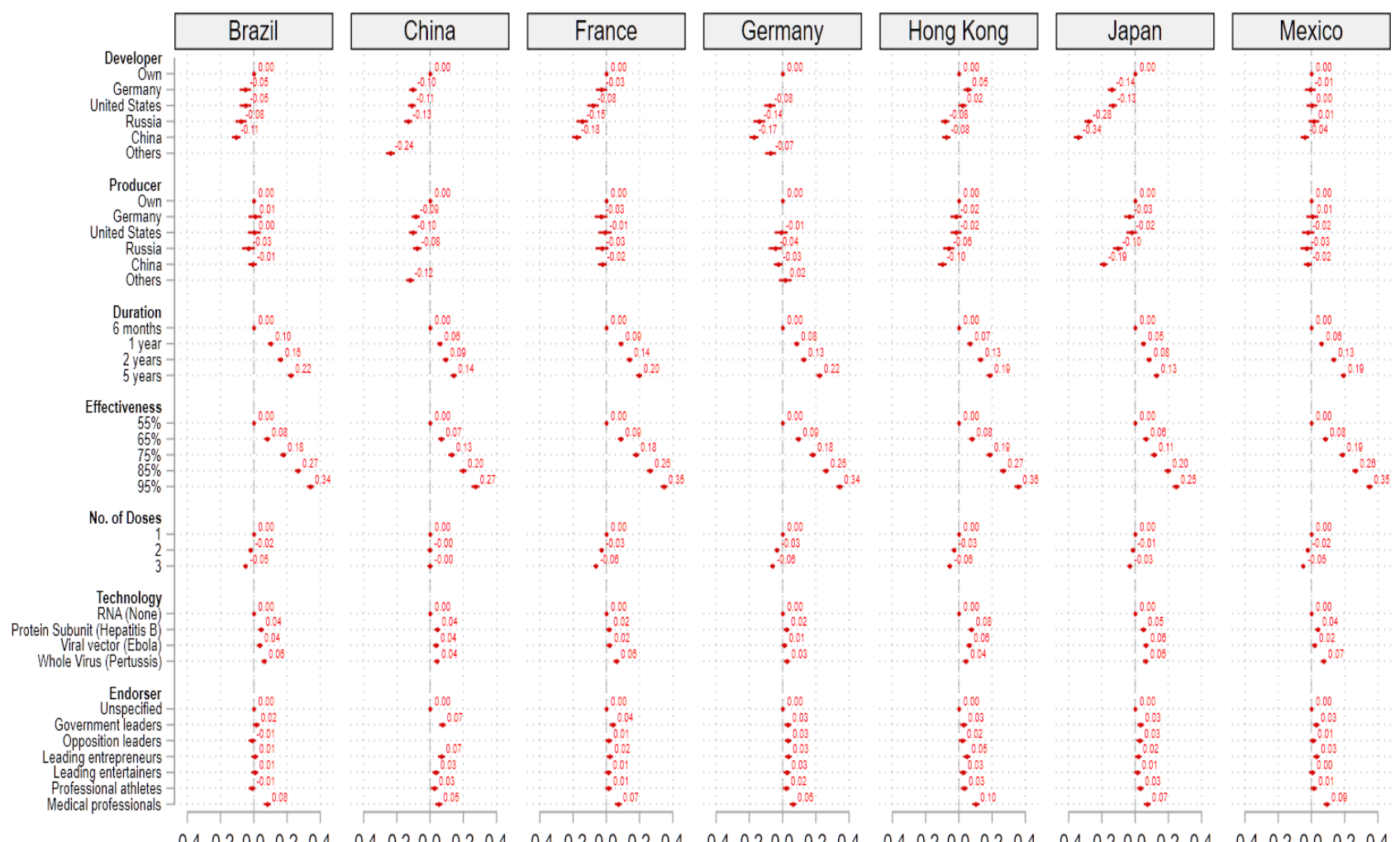

$\begin{array}{lllllllllllllllllllllllllllllllllllllll}-0.4 & -0.2 & 0.0 & 0.2 & 0.4 & -0.4 & -0.2 & 0.0 & 0.2 & 0.4 & -0.4 & -0.2 & 0.0 & 0.2 & 0.4 & -0.4 & -0.2 & 0.0 & 0.2 & 0.4 & -0.4 & -0.2 & 0.0 & 0.2 & 0.4 & -0.4 & -0.2 & 0.0 & 0.2 & 0.4 & -0.4 & -0.2 & 0.0 & 0.2 & 0.4\end{array}$

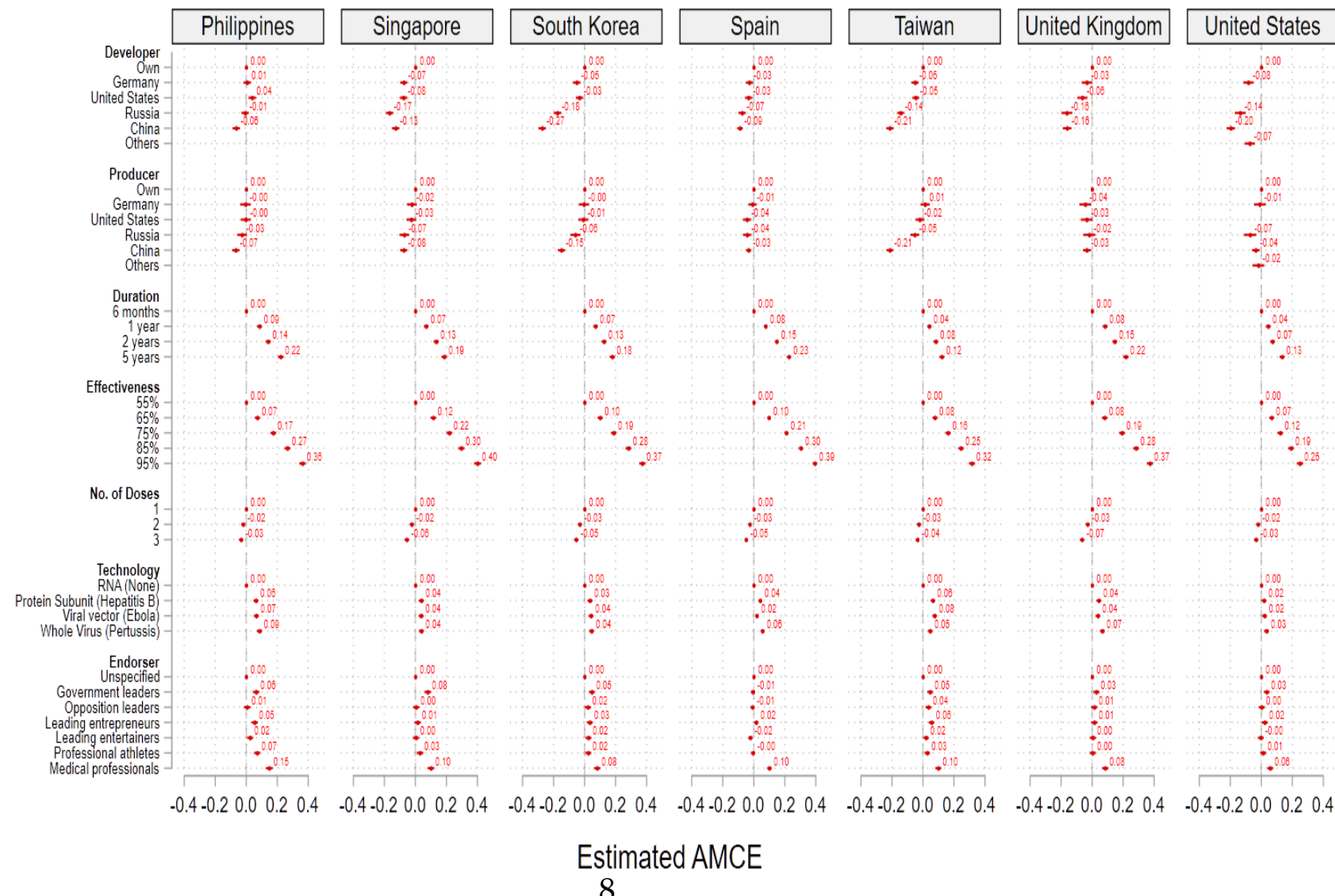


As Figure 4 also illustrates, disfavor for foreign vaccines is larger among the high nationalism group across all comparison countries. While the own- country bias is substantively small - i.e., 2 percentage points - when compared to vaccines developed in Germany and the United States among low nationalistic respondents $(P<0.001)$, the effect is three-folded - i.e., 6 percentage points - for both countries among high nationalistic respondents $(\mathrm{P}<0.001)$. This subgroups analysis also shows a consistent pattern regarding vaccines developed in Russia and China with low nationalistic subgroups disfavoring them by 10 and 12 percentage points respectively compared to 12 and 15 percentage points respectively among the high nationalistic subgroup. This implies a differential effect of 2 and 3 percentage points between the two subgroups (where both differential effects achieve statistical significance at the $\mathrm{P}<0.001)$. Further, the difference in the effect between the high and the low nationalism groups still largely persists in individual national samples, the only exceptions being the samples from Mexico and the Philippines. As far as vaccine production is concerned, highly nationalistic respondents discriminate against vaccines manufactured in Germany ( 3 percentage points, $\mathrm{P}<0.001$ ) and the United States (5 percentage points, $\mathrm{P}<0.001$ ), which contrasts with the no-bias demonstrated between homegrown vaccines and those produced in Germany ( 0 percentage points, n.s.) and the United States (1 percentage point, n.s.) among those with less intense nationalistic feelings. By contrast, the bias against vaccines manufactured in Russia and China is homogeneously strong and negative for all nationalism subgroups (28).

\section{Discussion}

We report a conjoint experiment testing whether the nation of vaccine development and production influences the probability of accepting a vaccine that includes representative samples from 14 nations around the world. We find a significant country-of-origin bias 
Fig. 4 AMCEs across Nationalism (25/75). Table S5 presents the regression estimates plotted in this figure. Online Appendix 1.4 describes how Nationalism was coded. The sample is split in two groups: the first and the fourth quartile of the within-country Nationalism distribution. Low Nationalism identifies respondents in the first quartile of the within-country Nationalism distribution; i.e., respondents between the smallest value of the distribution and the middle number that falls between the smallest value of the distribution and the median. High Nationalism identifies respondents in the fourth quartile of the nationalism distribution; i.e., respondents between the middle number that falls between the median and the largest value in the distribution.
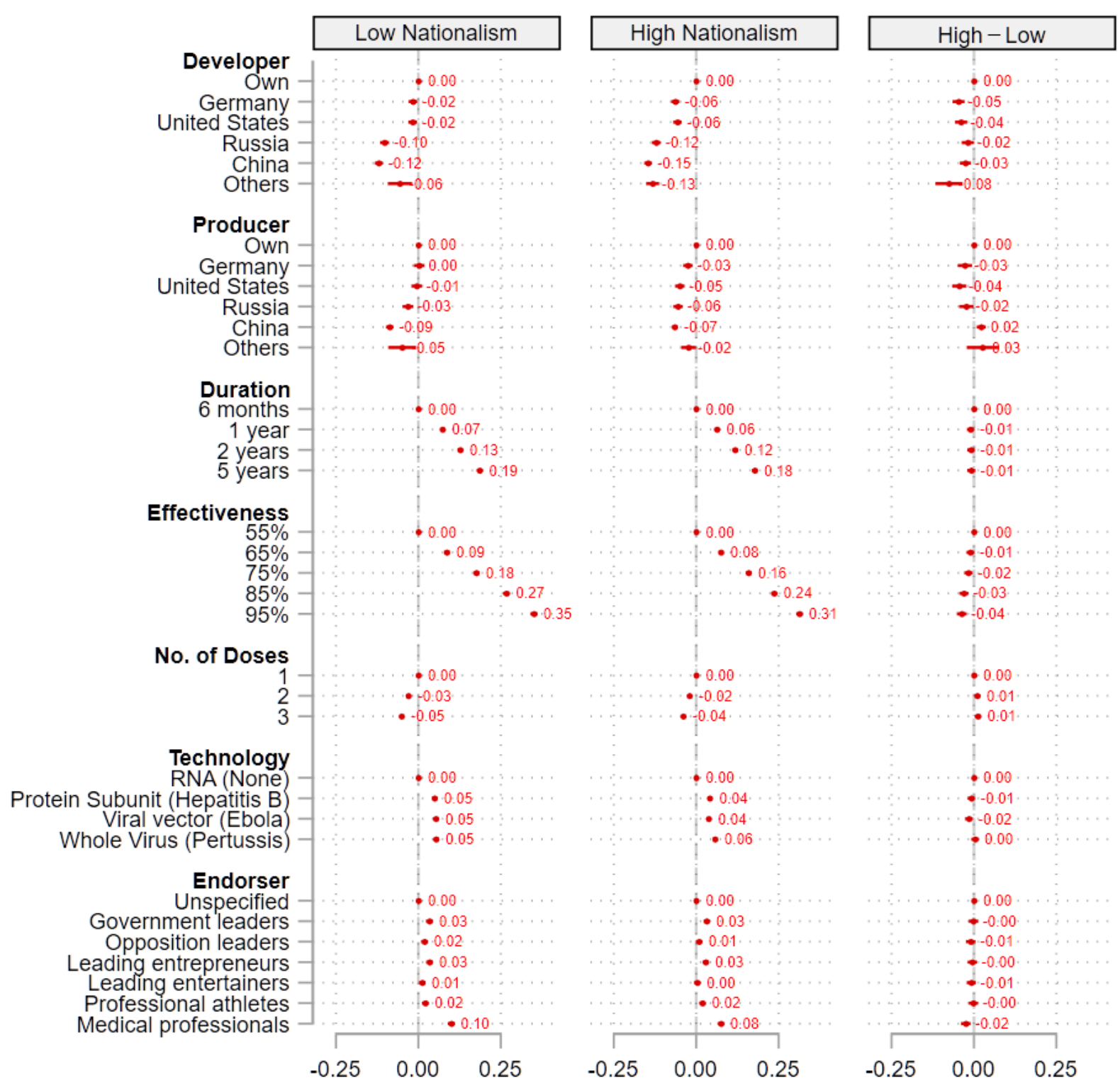

Estimated AMCE 
in favor of vaccines developed and produced locally. We also report our experiment on a country-by-country basis showing that the pattern emerges in almost all individual country samples. Furthermore, we show that citizens who report strong feelings of attachment toward their country are systematically more likely to favor vaccines from their own nation rather than vaccines developed overseas.

While the randomization of attributes ensures the internal validity of the effects we identify, some questions may remain on the external validity of our study. Some components help us alleviate these concerns. While our experiment cannot provide direct evidence that people will take one vaccine over another in the real world - conjoint experiments have been systematically found to provide close approximation of people's real-life behavior (25) and can help avoid social desirability bias, which is a common concern of survey studies (29). In this context, field experiments where vaccine attributes are randomly assigned to individuals would likely be unfeasible and unethical. Therefore, we believe that conjoint experiments such as ours provide the most practical and ethical approach for identifying determinants of the public's vaccine preference.

Additionally, the homogeneity of our estimates across gender and age subgroups gives us confidence that our findings are close to representing a population-level average treatment effect. Further, we have found the effect to be relatively consistent across 14 countries, which vary greatly on a number of country-level attributes such as economic development, regime type, vaccination acceptance, and vaccination roll-out. However, we acknowledge that our sample of countries includes mostly upper and upper-middle income countries. None of the countries we studied can, in fact, be considered a lowincome country. While we admit that it is important to assess whether similar results would hold in low-income countries with a nascent or non-existing national vaccine industry, the reduced penetration of Internet and the impossibility of conducting faceto-face interviews amidst a global pandemic makes it difficult to obtain the sort of highquality survey data necessary for this type of assessment. 
Despite this, our findings have relevance for several theoretical and applied questions. Earlier research has shown that some forms of group identification can shape support for and engagement in protective behavioral measures (30-33). Contributing to this literature, we underscore the potential danger of the sociological dimension of vaccine nationalism whereby citizens, especially those strongly identified with their own nation, prefer vaccines developed and produced in their own nations to the exclusion or detriment of equivalent vaccines from other nations. National identification, which might be particularly salient amidst a global health crisis (34), largely drives biases toward vaccines, which might hamper vaccine uptake. In a context where not all countries have a homegrown vaccine available to their citizens, prejudice and bias against foreign vaccines create an obstacle in the race to inoculate a large portion of the global community to ensure mass immunity to the disease. However, our findings are not all pessimistic.

Uncovering the public's preference for homegrown vaccines can help devise policy for improving vaccine uptake. This paper provides critical evidence in favor of vaccine development and production by local pharmaceutical companies. Our findings also demonstrate a need for international collaboration in the development and production of vaccines - discouraging single-country, single-company efforts - in order to heighten worldwide vaccine acceptance, including multinational joint-ventures and patent-sharing. Third, we show that, even if vaccines are developed abroad, those that are produced locally are more favored. This suggests that the decentralization of vaccine production could boost vaccine acceptance.

Additionally, our findings illuminate the potential benefit of more tailored communication approaches to increase vaccination uptake on a local level. The simplest communication strategies have long proved ineffective to persuade people to inoculate themselves via vaccine (35). This is consistent with our findings that vaccine fundamental attributes only partially determine the public's vaccine acceptance. Thus far, researchers 
have named various potentially effective strategies to address vaccine hes- itancy, such as combating the spread of false information (36), highlighting personal benefits of vaccination in communication materials (37), leveraging the role of emotion in communication (38), improving education of vaccine providers and their interaction with receivers (39), and devising culturally tailored promotion strategies (40). However, our findings suggest that it is critical that governments and pundits make efforts to de-bias citizens with regards to the variables of country of development and production. For instance, our data suggests that de-emphasizing, or even removing, the country of origin when communicating about a vaccine could increase its acceptance. Subsequent research should specifically evaluate whether references to the American vaccine, the British vaccine, or the

Chinese vaccine might increase vaccine uptake in the United States, the United Kingdom, and China, respectively, at the cost of reducing its acceptance anywhere else.

\section{Methods}

The research and procedure (including the informed consent forms) were approved by the corresponding Institutional Review Board of authors' institutions.

\section{Survey participants}

We fielded Internet-based surveys in fourteen countries around the world. We selected the sample to reflect an array of national attributes, including geographic representation from Europe, South and Central America, Southeast and Eastern Asia, high-income and middle-income countries, large and small, countries with major and minor political influence, and varying degrees of vaccine acceptance rate (China and Brazil close to or above $80 \%$ and France below $60 \%$ as previously shown in (6)) and varying levels of vaccination roll-out at the time of fieldwork (United Kingdom and United States with over $50 \%$ of the population with at least one dose and Japan and South Korea with less than $10 \%$ of the population). Table S1 reports a list of all countries selected for the fieldwork, the number of respondents, and the fieldwork period.

The survey firm Respondi was responsible for the fieldwork in Brazil, France, Germany, Mexico, Spain, United Kingdom, and United States. The survey firm Rakuten was responsible for the fieldwork in China, Hong Kong, Japan, the Philippines, Singapore, South Korea, and Taiwan. Both firms use mostly online channels to recruit new panelists for its online panels. After completing a basic questionnaire with sociodemographic information, panelists are invited to complete more surveys. Survey firms compensate their panelists for each survey they complete. The modal incentive across the countries fielded by Respondi was $\$ 1$ for a median length of 
interview (LOI) of 10 minutes. For the surveys fielded by Rakuten, the modal incentive was $\$ 1.5$ for a median length of interview (LOI) of 10 minutes.

The recruitment of panelists employed age, gender, and major region quotas to roughly match the population margins for each of the fourteen countries in our study. Table S3 reports descriptive statistics for the pooled sample.

\section{Experimental design}

We designed a conjoint experiment and embedded it in online public opinion surveys that we fielded in 14 countries around the world. We used conjoint methods to evaluate the association of vaccine attributes with the decision to choose a type of COVID-19 vaccine. This experimental design has been widely employed in marketing research to examine consumer preferences (21) and has been increasingly used in the social sciences $(22,41)$ and medical research $(24,42-44)$.

We employed a fully randomized paired conjoint design in which respondents were presented with two hypothetical COVID-19 vaccines displayed side-by-side as illustrated in Figure S1(45). displays an example of a pair of vaccine profiles shown to respondents. Specifically, this example comes from the English version of the survey administered to respondents in the United States. Each respondent saw and evaluated fifteen paired vaccine profiles. While survey satisfaction and respondent fatigue is a concern when using multiple conjoint tasks with the same respondents, scholars have shown that response quality does not decline even after 30 conjoint tasks(46). The order of the attributes were fully randomized for each respondent and conjoint task. The specific attribute levels were randomized between and within respondent groups.

This design outperforms other conjoint designs and vignettes in minimizing social desirability bias and predicting real-world behavior(25). Table $\mathbf{S 2}$ reports all vaccine attributes and possible values, which included the following seven randomized attributes:

1. Country of vaccine invention/development, with five possible values including own respondents' country, United States, Germany, Russia, and China, or another fifth country in samples from the United States, Germany, and China. The fifth country in the U.S. sample was the United Kingdom, in the German sample was France, and in the Chinese sample was India.

2. Country of vaccine production, with five possible values including own respondents' country, United States, Germany, Russia, China, or another fifth country in samples from the United States, Germany, and China. The fifth country in the U.S. sample was the United Kingdom, in the German sample was France, and in the Chinese sample was India. Randomization of this item was designed to take the same value as the country of vaccine invention/development half of the time, and China the other half.

3. Efficacy rate, with increments of $10 \%$ from $55 \%$ to $95 \%$.

4. Duration of the vaccine protection, with four possible values: 6 months, 1 year, 2 years, and 5 years.

5. Number of doses with 3 values: 1 injection, 2 injections at least 21 days apart, or 3 injections at least 21 days apart. 
6. Vaccine technology with four possible values: RNA viral vector, whole virus, and protein subunit. In a different row, we also present the attribute of other vaccines using the same vaccine technology, which shows responses to the pre-existing vaccine using the same technology as the hypothetical COVID-19 vaccine. This item is not randomized but it is linked to vaccine technology. Currently there are no other licensed vaccines using RNA vaccines, Ebola is a pre-existing vaccine using viral vector vaccine technology; whooping cough, Rabies, Hepatities A, etc. use whole virus, and Hepatitis B uses protein subunit vaccine technology. As these two attributes fully vary together, we present both with the same coefficient in our results.

7. Actors who have publicly endorsed the vaccine with seven possible values including unknown or not yet decided, government official leaders, opposition party leaders, famous soccer players, famous entertainers, leading entrepreneurs, and medical professionals. The survey conducted in China had to be adjusted to accommodate local restrictions. In China, we replaced opposition party leaders with members of the Chinese Communist Party (CCP). Because there is significant overlap between Chinese government official leaders and CCP members, we treat them as government official leaders in our pooled estimates and report no coefficient for opposition party leaders.

\section{Outcomes}

After seeing the pair of vaccines, interviewees were asked to choose the vaccine they would prefer to take. We created a binary choice outcome variable using these responses, which corresponded with a 1 for the most preferred vaccine profile and 0 for the least preferred vaccine profile.

\section{Survey text}

The exact wording of the survey questions reads as follows:

- "If you had to choose between Vaccine A and Vaccine B, which one would you choose to take?"

The nationalism question was asked before the conjoint experimental task across all countries. The exact wording of the survey question is the following:

- "In relation to your feelings for the [respondents' country]. Where would you place yourself on a scale from 0 to 10 where 0 means 'Not proud at all to be [of your country]' and 10 means maximum 'extremely proud to be [of your country]'?" (version administered in Brazil, France, Germany, Mexico, Spain, United Kingdom, and United States)

- "Do you agree with the following statement? The world would be a better place if people of other countries behave like people of our country" (version administered in China, Hong Kong, Japan, Philippines, Singapore, South Korea, and Taiwan).

To construct the nationalism variable, we standardized the variable for each country sample. In this way, every country has a Nationalism variable with a mean of 0 and a standard deviation of 1 . 
The willingness to take the vaccine question was asked before the conjoint experimental task across all countries. The exact wording of the survey question is as follows:

- Respondents who have not yet been offered a vaccine are asked the following question: "Once a vaccine is offered to you, what is the probability that you will take it?" Response is given in a 7-point scale from "Very unlikely" to "Very likely". Respondents who have already received one dose of the vaccine are considered as "Very likely". Finally, respondents who have been offered a vaccine but have decided not to take it are considered as Very unlikely (version administered in Brazil, France, Germany, Mexico, Spain, United Kingdom, and United States).

- "Scientists have developed Covid-19 vaccines, and our government is purchasing vaccines abroad and starting vaccination for the public. If 0 means that you would not consider taking Covid-19 vaccines and 10 means that you definitely take Covid-19 vaccines, where would you put yourself on this scale?" (survey version administered in China, Hong Kong, Japan, Philippines, Singapore, South Korea, and Taiwan).

To construct the willingness to take a vaccine variable, we re-scale both survey responses to a 11-point scale, ranging from 0 to 10.

\section{Survey translations}

The survey instrument was designed in English and then professionally translated into all main local languages in each area of study.

\section{Statistical analysis}

Each of the 15,648 respondents evaluated 15 pairs of vaccine profiles, resulting in a total of approximately 469,440 vaccine profiles being evaluated. We evaluated these responses using an Average Marginal Component-specific Effects (AMCE), which estimates the average causal effect of each attribute on respondents' acceptance of a vaccine profile. We estimate the AMCE by regressing the choice outcome on sets of attribute levels excluding one level of each attribute the reference category - and clustering the standard errors at the level of the respondent.

\section{Data Availability}

The datasets and code to replicate the tables and figures of this paper will be made publicly available upon publication.

\section{References}

1. C. Cheng, J. Barceló, A. S. Hartnett, R. Kubinec, L. Messerschmidt, COVID-19 government response event dataset (CoronaNet v. 1.0). Nature Human Behaviour 4, 756-768 (2020). 
2. E. Dong, H. Du, L. Gardner, An interactive web-based dashboard to track COVID-19 in real time. The Lancet Infectious Diseases 20, 533-534 (2020).

3. World Health Organization, COVID-19 vaccine tracker and landscape, 2021, (https : //www . who.int/publications/m/item/draft-landscape-of-covid-19-candidate-vaccines).

4. E. Mathieu et al., A global database of COVID-19 vaccinations. Nature Human Behaviour, 1-7 (2021).

5. YouGov Data, YouGov-Data/covid-19-tracker, 2020, (https : //github . com/YouGov-Data / covid-19-tracker).

6. J. V. Lazarus et al., A global survey of potential acceptance of a COVID-19 vaccine. Nature Medicine 27, 225-228 (2021).

7. J. Solis Arce et al., COVID-19 vaccine acceptance and hesitancy in low and middle income countries, and implications for messaging. Nature Medicine (2021).

8. S. Lane, N. E. MacDonald, M. Marti, L. Dumolard, Vaccine hesitancy around the globe: Analysis of three years of WHO/UNICEF Joint Reporting Form data-2015-2017. Vaccine 36, 3861-3867 (2018).

9. World Health Organization, Ten threats to global health in 2019, 2019, (https : / / www - whoint . proxy . library . nyu . edu/news - room/spotlight/ten-threats - to-global - healthin-2019).

10. M. J. Hornsey, E. A. Harris, K. S. Fielding, The psychological roots of anti-vaccination attitudes: A 24-nation investigation. Health Psychology 37, 307 (2018).

11. E. Karafillakis, H. J. Larson, et al., The benefit of the doubt or doubts over benefits? A systematic literature review of perceived risks of vaccines in European populations. Vaccine 35, 4840-4850 (2017).

12. O. Yaqub, S. Castle-Clarke, N. Sevdalis, J. Chataway, Attitudes to vaccination: a critical review. Social Science \& Medicine 112, 1-11 (2014).

13. R. M. Kaplan, A. Milstein, Influence of a COVID-19 vaccine's effectiveness and safety profile on vaccination acceptance. Proceedings of the National Academy of Sciences 118 (2021).

14. J. Murphy et al., Psychological characteristics associated with COVID-19 vaccine hesitancy and resistance in Ireland and the United Kingdom. Nature Communications 12, 1-15 (2021).

15. K. Kupferschmidt, 'Vaccine nationalism' threatens global plan to distribute COVID-19 shots fairly. Science 28 (2020).

16. D. P. Fidler, Vaccine nationalism's politics. Science 369, 749-749 (2020).

17. D. Dong et al., Public preference for COVID-19 vaccines in China: A discrete choice experiment. Health Expectations 23, 1543-1578 (2020).

18. W. G. Gramacho, M. Turgeon, When politics collides with public health: COVID-19 vaccine country of origin and vaccination acceptance in Brazil. Vaccine 39, 2608-2612 (2021).

19. S. Kreps et al., Factors associated with US adults' likelihood of accepting COVID-19 vaccination. JAMA network open 3, e2025594-e2025594 (2020). 
20. The countries included are Brazil, China, France, Germany, Japan, Hong Kong, Mexico, the Philippines, Singapore, South Korea, Spain, Taiwan, United Kingdom, and the United States. These countries were chosen to represent a diversity of national attributes, including geographic representation from Europe, South and Central America, Southeast and Eastern Asia, high-income and low-income countries, large and small, countries with major and minor political influence, and varying degrees of vaccine acceptance rate - with China and Brazil close to or above $80 \%$ and France below $60 \%$ as previously shown in (6). The selected countries also represent varying levels of vaccination rollout at the time of fieldwork - the United Kingdom and the United States having over $50 \%$ of the population with at least one dose and Japan and South Korea with less than $10 \%$ of the population.

21. P. E. Green, A. M. Krieger, Y. Wind, Thirty years of conjoint analysis: Reflections and prospects. Interfaces 31, S56-S73 (2001).

22. J. Hainmueller, D. J. Hopkins, T. Yamamoto, Causal inference in conjoint analysis: Understanding multidimensional choices via stated preference experiments. Political analysis 22, 1-30 (2014).

23. T. J. Leeper, S. B. Hobolt, J. Tilley, Measuring Subgroup Preferences in Conjoint Experiments. Political analysis 28, 207-221 (2020).

24. C. V. Almario et al., Optimizing selection of biologics in inflammatory bowel disease: development of an online patient decision aid using conjoint analysis. American Journal of Gastroenterology 113, 58-71 (2018).

25. J. Hainmueller, D. Hangartner, T. Yamamoto, Validating vignette and conjoint survey experiments against real-world behavior. Proceedings of the National Academy of Sciences 112, 2395-2400 (2015).

26. We compute the pooled effect of a "foreign country" vis-á-vis the respondents' own country by aggregating the coefficients of individual countries, and excluding the filler category "Other countries".

27. As Figures $\mathbf{S 6}$ through $\mathbf{S 8}$ show, the effect is robust despite different ways of dividing higher and lower nationalism groups.

28. Marginal means (MMs) estimates are an important reference for AMCEs' causal interpretation and subgroup comparisons in a context when there are no well-defined baselines in a conjoint experiment (23). While this is not a concern for our experiment since the homegrown vaccine was a natural choice, the MMs reported in Figure S7 show that our results remain unchanged.

29. E. M. Caruso, D. A. Rahnev, M. R. Banaji, Using Conjoint Analysis to Detect Discrimination: Revealing Covert Preferences From Overt Choices. Social Cognition 27, 128-137 (2009).

30. H. Allcott et al., Polarization and public health: Partisan differences in social distancing during the coronavirus pandemic. Journal of Public Economics 191, 104254 (2020).

31. J. Barceló, G. C.-H. Sheen, Voluntary adoption of social welfare-enhancing behavior: Maskwearing in Spain during the COVID-19 outbreak. PLOS ONE 15, e0242764 (2020).

32. A. Gollwitzer et al., Partisan differences in physical distancing are linked to health outcomes during the COVID-19 pandemic. Nature human behaviour 4, 1186-1197 (2020).

33. J. J. Van Bavel et al., National identity predicts public health support during a global pandemic. (2020). 
34. F. Bieber, Global nationalism in times of the COVID-19 pandemic. Nationalities Papers, 1-13 (2020).

35. A. Thomson, G. Vallée-Tourangeau, L. S. Suggs, Strategies to increase vaccine acceptance and uptake: From behavioral insights to context-specific, culturally-appropriate, evidencebased communications and interventions. Vaccine 36, 6457-6458 (2018).

36. M. Arede et al., Combating Vaccine Hesitancy: Teaching the Next Generation to Navigate Through the Post Truth Era. Frontiers in Public Health 6, 381 (2019).

37. D. Freeman et al., Effects of Different Types of Written Vaccination Information on COVID19 Vaccine Hesitancy in the UK (OCEANS-III): a Single-blind, Parallel-group, Randomised Controlled Trial. The Lancet Public Health 6, e416-e427 (2021).

38. W.-Y. S. Chou, A. Budenz, Considering Emotion in COVID-19 Vaccine Communication: Addressing Vaccine Hesitancy and Fostering Vaccine Confidence. Health Communication 35, 1718-1722 (2020).

39. J. Leask, H. W. Willaby, J. Kaufman, The big picture in addressing vaccine hesitancy. Human Vaccines \& Immunotherapeutics 10, 2600-2602 (2014).

40. R. Nagar et al., A Cluster Randomized Trial to Determine the Effectiveness of a Novel, Digital Pendant and Voice Reminder Platform on Increasing Infant Immunization Adherence in Rural Udaipur, India. Vaccine 36, 6567-6577 (2018).

41. K. Bansak, J. Hainmueller, D. Hangartner, How economic, humanitarian, and religious concerns shape European attitudes toward asylum seekers. Science 354, 217-222 (2016).

42. D. Makarov et al., American Urological Association and Society for Medical Decision Making Quality Improvement Summit 2016: shared decision making and prostate cancer screening. Urology Practice 5, 444-51 (2018).

43. S. Spaich et al., Patient preferences regarding chemotherapy in metastatic breast cancer-a conjoint analysis for common taxanes. Frontiers in oncology 8, 535 (2018).

44. G. A. Wildenbos, F. Horenberg, M. Jaspers, L. Peute, D. Sent, How do patients value and prioritize patient portal functionalities and usage factors? A conjoint analysis study with chronically ill patients. BMC medical informatics and decision making 18, 1-10 (2018).

45. While the variables country of development and invention are fully randomized across five countries, the variable vaccine of production is constrained to take either the same value as the country of development/invention or China. This decision aims at increasing statistical efficacy and avoiding unrealistic combinations. In this way, our respondents half of the time face a vaccine that has the same country of invention and production, and the other half the country of production is different from the invention.

46. K. Bansak, J. Hainmueller, D. J. Hopkins, T. Yamamoto, The number of choice tasks and survey satisficing in conjoint experiments. Political Analysis 26, 112-119 (2018). 


\section{Supplementary Information}

1 Figures 2

2 Tables $\quad 9$ 


\section{Figures}

Fig. S1 Example profile pair. This figure displays an example of a pair of vaccine profiles shown to respondents. This example comes from the version of the survey shown to respondents in the United States. Each respondent saw and evaluated fifteen paired vaccine profiles.

Now, evaluate the tollowing two vaccines:

\begin{tabular}{|c|c|c|}
\hline & Vaccine A & Vaccine B \\
\hline Efficacy rate & $85 \%$ & 2 years \\
\hline Duration of the protection & 5 years & Ebola \\
\hline Other vaccines using a similar technology & Whooping cough, Rabies, Hepatities A, etc. & China \\
\hline Country of production & United Kingdom & Viral vector \\
\hline Vaccine technology & Whole virus & 3 injections, at least 21 days apart \\
\hline Number of doses & 1 injection & Opposition party leaders \\
\hline Who is willing to get the vaccine & Leading enterpreneurs & China \\
\hline Country of invention & United Kingdom & Yver 20 countries, including the U.S. \\
\hline FDA Authorization & Over 20 countries, including the U.S. & Yes \\
\hline
\end{tabular}

If you had to choose between Vaccine $A$ and Vaccine B, which one would you choose to take? 
Fig. S2 AMCEs across Nationalism (40/60). Table S6 presents the regression estimates plotted in this figure. Online Appendix 1.4 describes how Nationalism was coded. The sample is split in two groups according to their position in the within-country distribution of Nationalism. In the first group, Low Nationalism identifies respondents between the smallest value and 40th percentile of the within-country distribution of Nationalism. In the second group, High Nationalism identifies respondents between 40th percentile and the largest value of the within-country distribution of Nationalism.
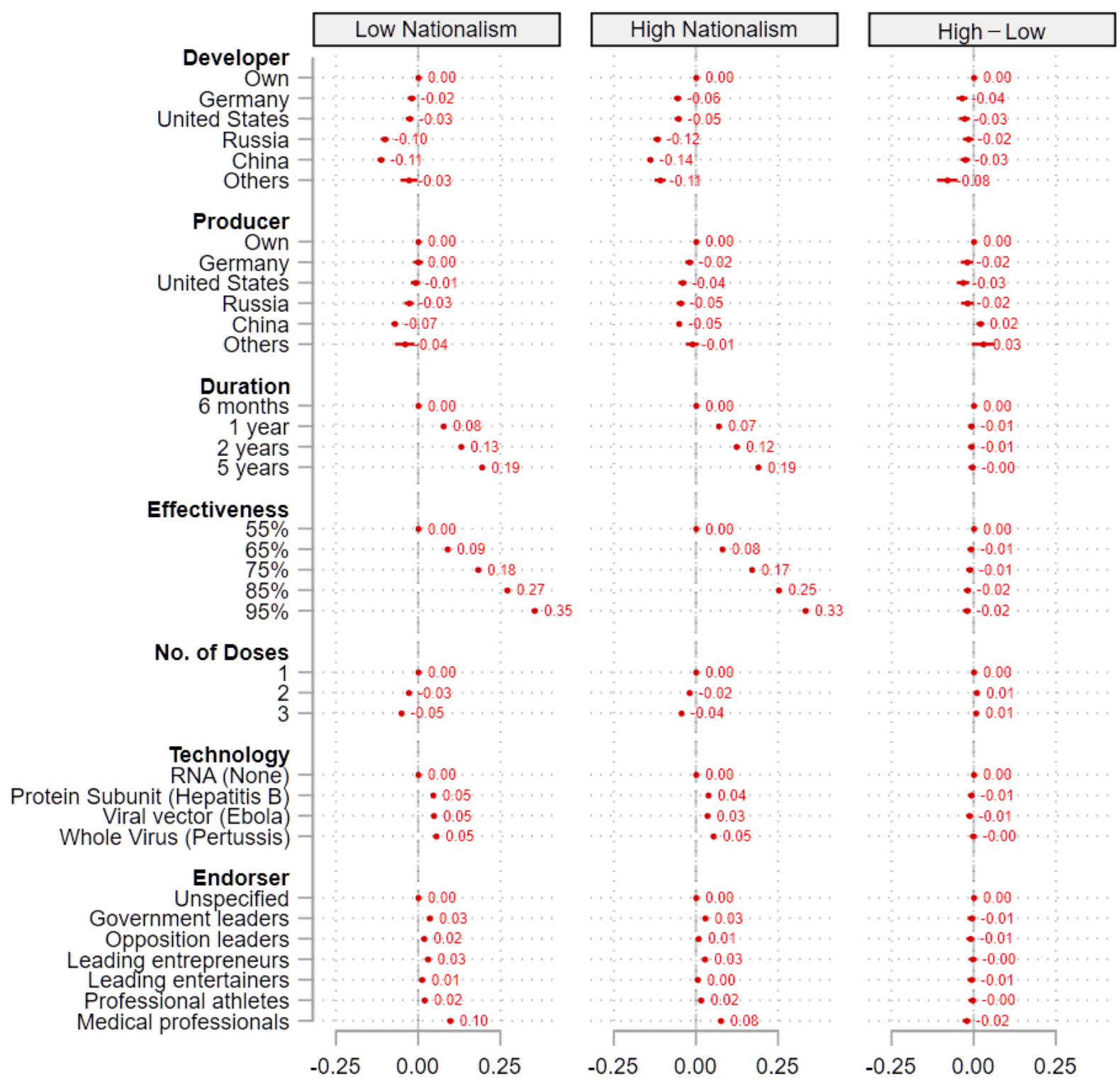

Estimated AMCE 
Fig. S3 AMCEs across Nationalism (30/70). Table S7 presents the regression estimates plotted in this figure. Online Appendix 1.4 describes how Nationalism was coded. The sample is split in two groups according to their position in the witihin-country distribution of Nationalism. In the first group, Low Nationalism identifies respondents between the smallest value and 30th percentile of the within-country distribution of Nationalism. In the second group, High Nationalism identifies respondents between 30th percentile and the largest value of the within-country distribution of Nationalism.
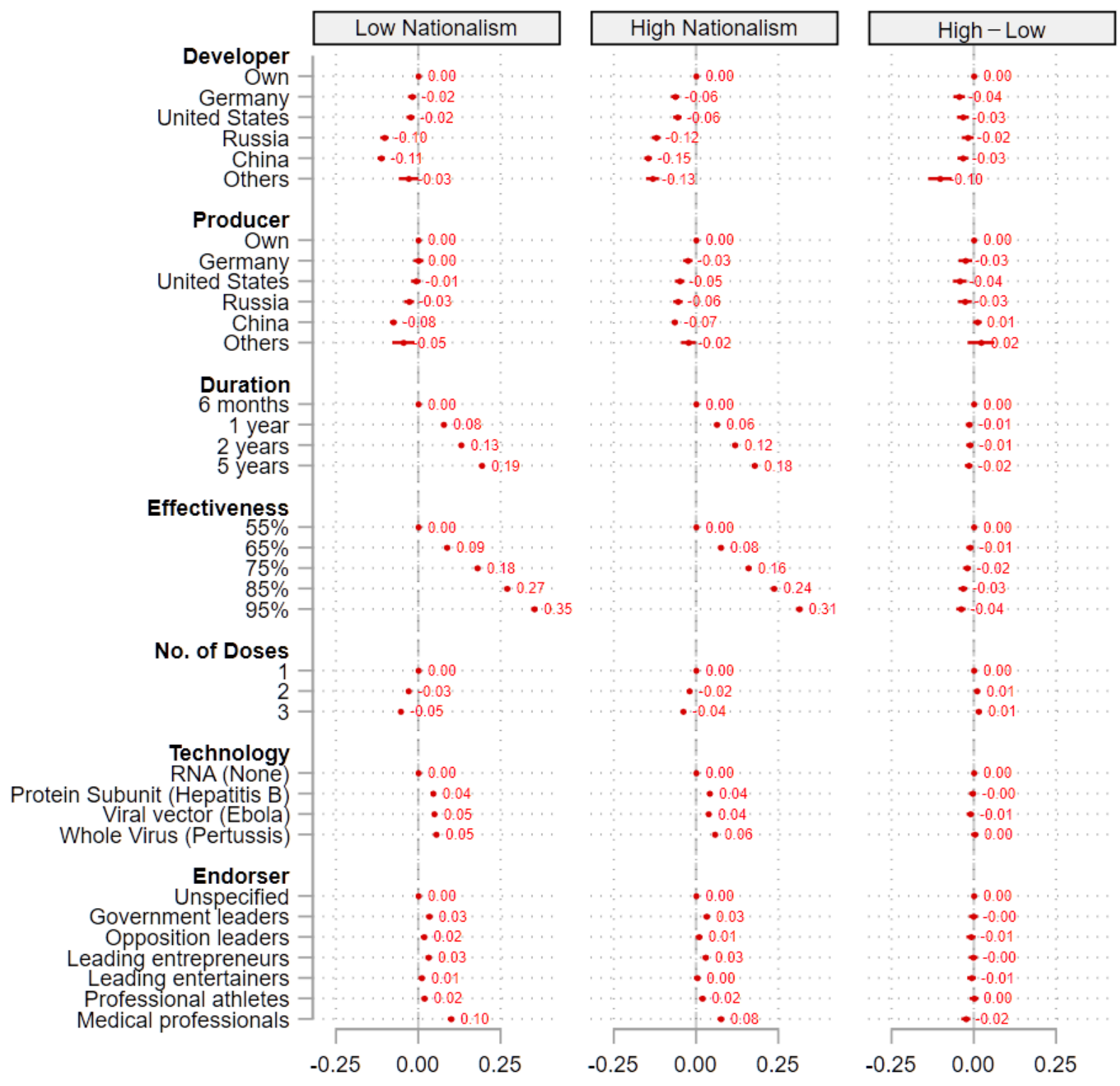

Estimated AMCE 
Fig. S4 AMCEs across Nationalism (20/80). Table S8 presents the regression estimates plotted in this figure. Online Appendix 1.4 describes how Nationalism was coded. The sample is split in two groups according to their position in the within-country distribution of Nationalism. In the first group, Low Nationalism identifies respondents between the smallest value and 20th percentile of the within-country distribution of Nationalism. In the second group, High Nationalism identifies respondents between 20th percentile and the largest value of the within-country distribution of Nationalism.
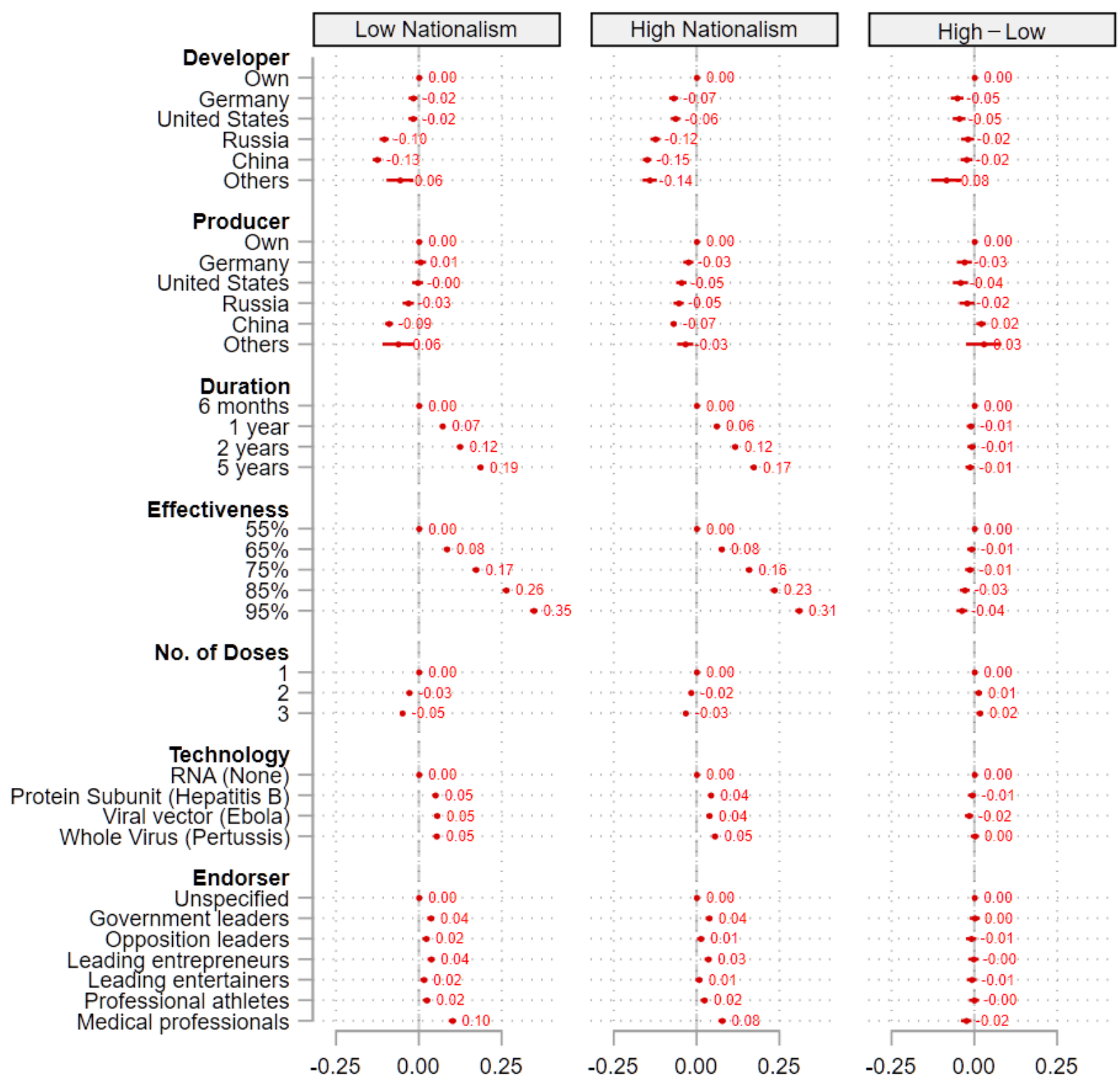

Estimated AMCE 
Fig. S5 AMCEs across gender. Tables S9 and S10 present the regression estimates plotted in this figure.

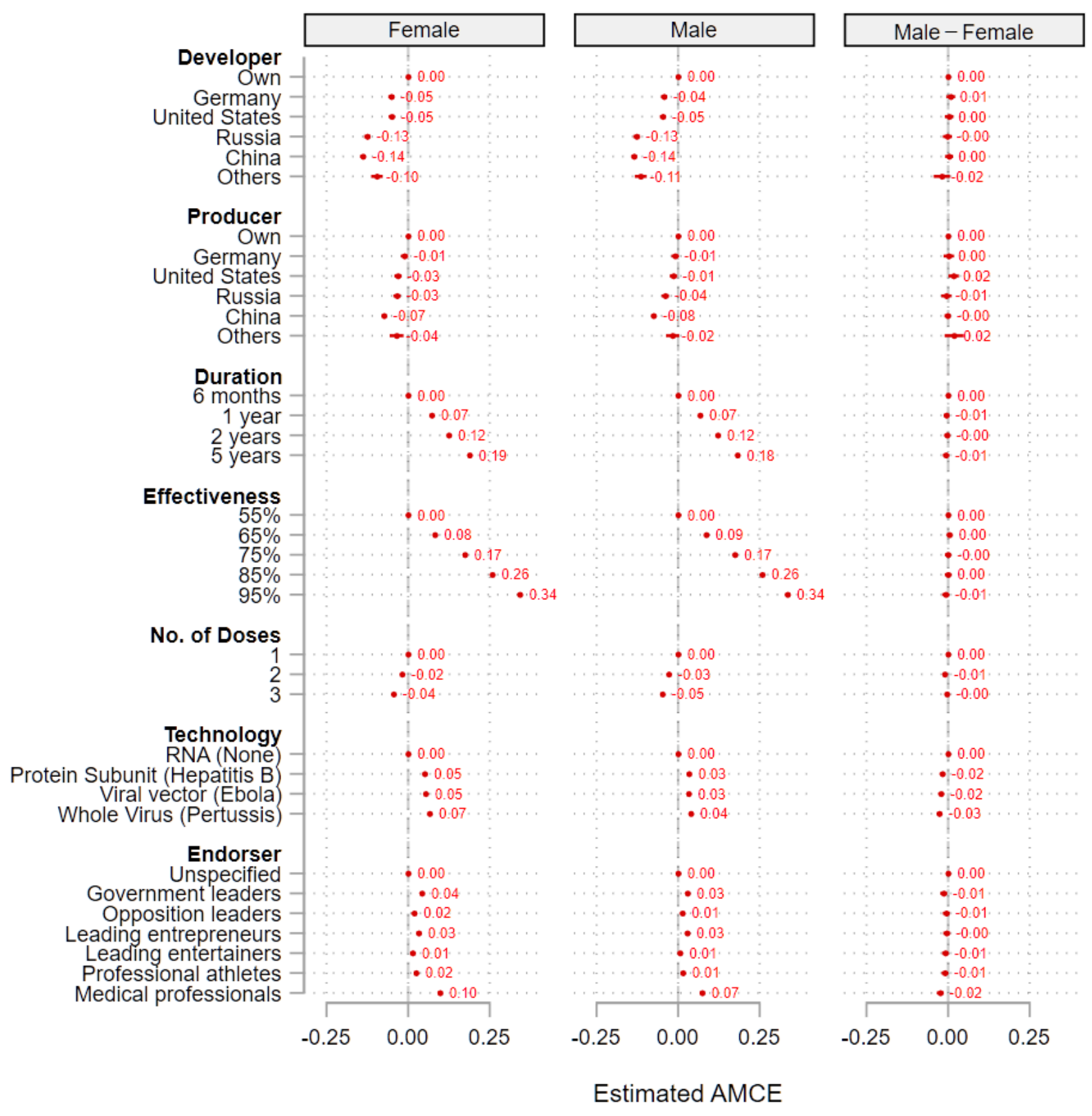


Fig. S6 AMCEs across age groups. Tables S11 through S16 present the regression estimates plotted in this figure.

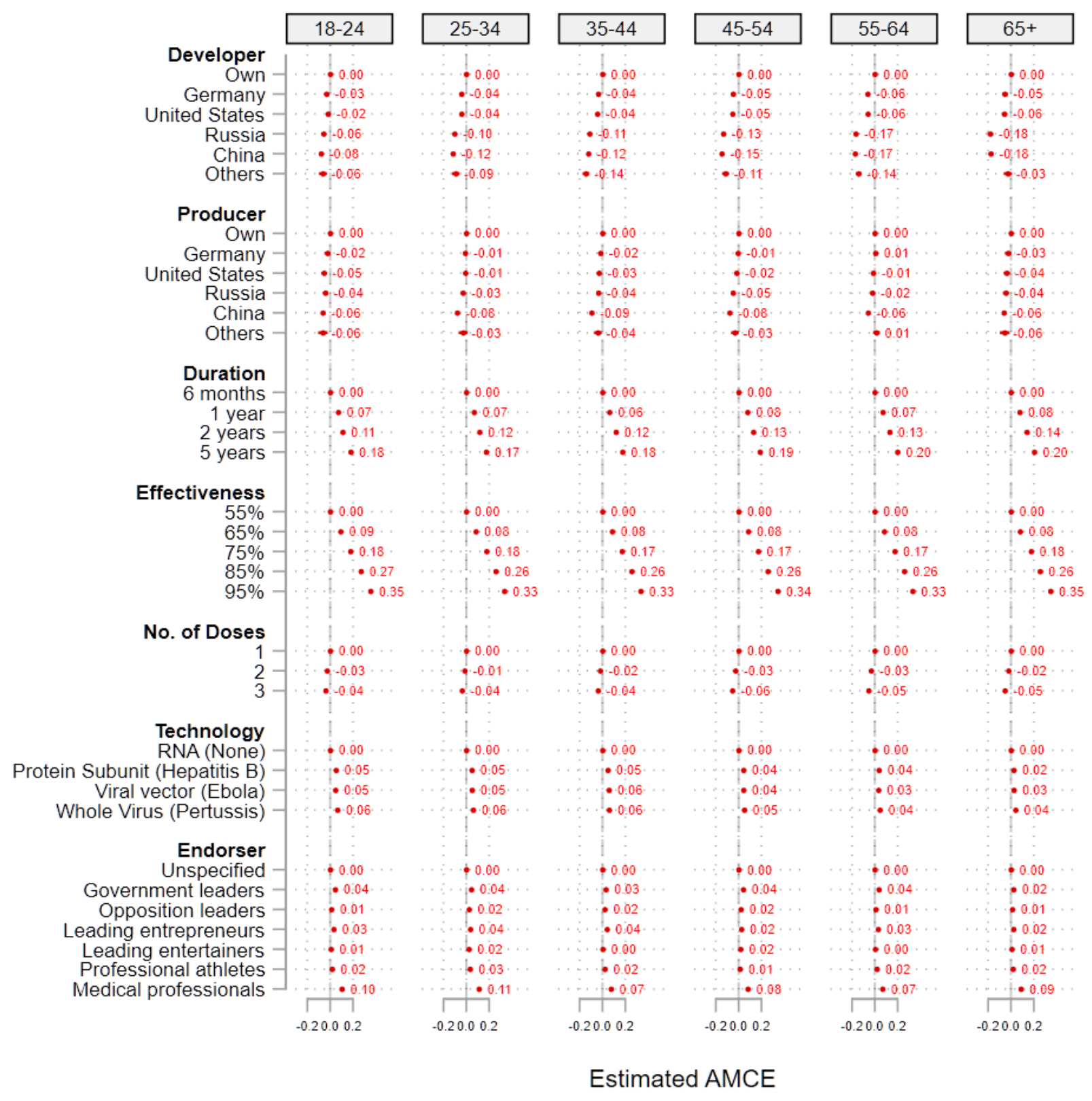


Fig. S7 Pooled marginal means across Nationalism (25/75).

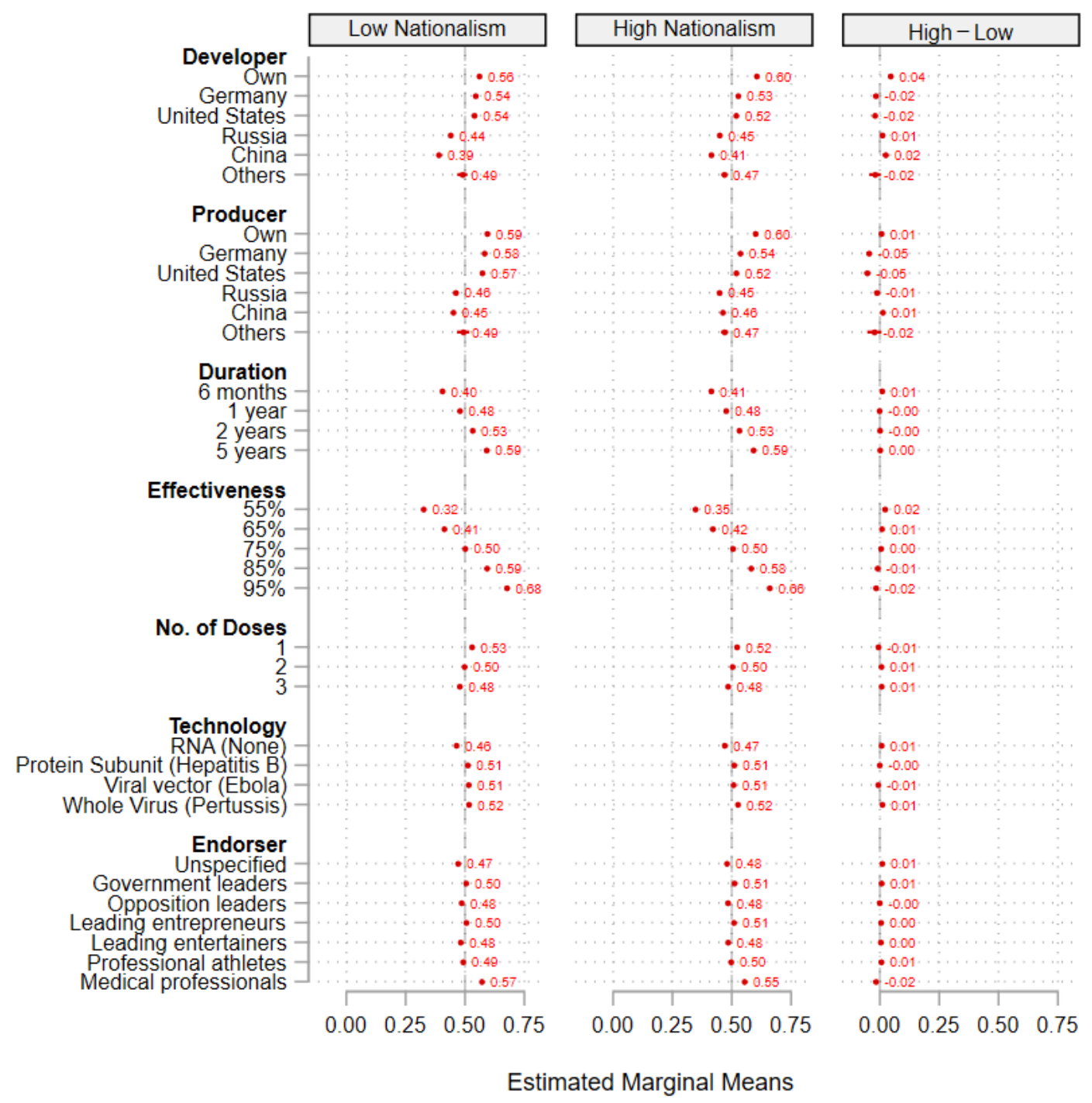




\section{Tables}

Table S1 Fieldwork period and number of respondents per country

\begin{tabular}{|c|c|c|}
\hline Country & Fieldwork period & $\mathbf{N}$ \\
\hline Brazil & May 6, 2021 - May 25, 2021 & 1016 \\
\hline China & May 3, 2021 - May 7, 2021 & 1001 \\
\hline France & April 20, 2021 - May 6, 2021 & 1048 \\
\hline Germany & April 28, 2021 - May 10, 2021 & 1031 \\
\hline Hong Kong & May 3, 2021 - May 7, 2021 & 1000 \\
\hline Japan & May 17, 2021 - May 20, 2021 & 1000 \\
\hline Mexico & April 5, 2021 - April 13, 2021 & 1175 \\
\hline Philippines & May 17, 2021 - May 21, 2021 & 999 \\
\hline Singapore & May 17, 2021 - May 20, 2021 & 1000 \\
\hline South Korea & May 17, 2021 - May 20, 2021 & 1000 \\
\hline Spain & March 1, 2021 - March 10, 2021 & 2000 \\
\hline Taiwan & March 16, 2021 - March 30, 2021 & 1202 \\
\hline United Kingdom & April 12, 2021 - April 19, 2021 & 1041 \\
\hline United States & May 14, 2021 - June 14, 2021 & 1135 \\
\hline Total & March 1, 2021 - June 14, 2021 & 15648 \\
\hline
\end{tabular}


Table S2 Conjoint attributes and attribute levels

\begin{tabular}{|c|c|}
\hline Attributes & Levels \\
\hline Country of invention/development & $\begin{array}{l}\text { Own country (ref. category) } \\
\text { United States } \\
\text { Germany } \\
\text { Russia } \\
\text { China } \\
\text { Another country }\end{array}$ \\
\hline Country of production & $\begin{array}{l}\text { Own country (ref. category) } \\
\text { United States } \\
\text { Germany } \\
\text { Russia } \\
\text { China } \\
\text { Another country }\end{array}$ \\
\hline Efficacy rate & $\begin{array}{l}55 \% \text { (ref. category) } \\
65 \% \\
75 \% \\
85 \% \\
95 \%\end{array}$ \\
\hline Duration of the vaccine protection & $\begin{array}{l}6 \text { months (ref. category) } \\
1 \text { year } \\
2 \text { years } \\
5 \text { years }\end{array}$ \\
\hline Number of doses & $\begin{array}{l}1 \text { injection (ref. category) } \\
2 \text { injections, at least } 21 \text { days apart } \\
3 \text { injections, at least } 21 \text { days apart }\end{array}$ \\
\hline Vaccine technology & $\begin{array}{l}\text { RNA (ref. category) } \\
\text { Viral vector } \\
\text { Whole virus } \\
\text { Protein subunit }\end{array}$ \\
\hline Other vaccines using the same vaccine technology & $\begin{array}{l}\text { No other licensed vaccines (ref. category) } \\
\text { Ebola } \\
\text { Whooping cough, Rabies, Hepatities A, etc. } \\
\text { Hepatitis B }\end{array}$ \\
\hline Actors who have publicly endorsed the vaccine & $\begin{array}{l}\text { Unspecified (ref. category) } \\
\text { Government officials leaders } \\
\text { Opposition party leaders } \\
\text { Famous soccer players } \\
\text { Famous entertainers } \\
\text { Leading enterpreneurs } \\
\text { Medical professionals }\end{array}$ \\
\hline
\end{tabular}


Table S3 Summary statistics for the pooled sample

\begin{tabular}{|c|c|c|c|c|c|}
\hline Variable & $\mathrm{N}$ & Mean & Std. dev. & Min. & Max. \\
\hline \multicolumn{6}{|l|}{ Gender } \\
\hline Female & 15649 & 0.505 & 0.500 & 0 & 1 \\
\hline Male & 15649 & 0.495 & 0.500 & 0 & 1 \\
\hline \multicolumn{6}{|l|}{ Age } \\
\hline $18-24$ & 15648 & 0.117 & 0.321 & 0 & 1 \\
\hline $25-34$ & 15648 & 0.196 & 0.397 & 0 & 1 \\
\hline $35-44$ & 15648 & 0.202 & 0.401 & 0 & 1 \\
\hline $45-54$ & 15648 & 0.197 & 0.398 & 0 & 1 \\
\hline $55-64$ & 15648 & 0.166 & 0.372 & 0 & 1 \\
\hline $65+$ & 15648 & 0.123 & 0.329 & 0 & 1 \\
\hline Willingness to take a COVID-19 vaccine & 15519 & 7.527 & 3.343 & 0 & 10 \\
\hline Nationalist attitudes & 15473 & 6.514 & 2.947 & 0 & 10 \\
\hline
\end{tabular}


Table S4 Pooled regression results. This model is used to construct the conjoint plot presented in Figure 2 of the main text. See Tables S17 through S30 for regression results per each country.

(1)

Vaccine Choice $(0 / 1))$

\begin{tabular}{|c|c|c|}
\hline \multicolumn{3}{|l|}{ Developer } \\
\hline Own & 0.000 & (.) \\
\hline Germany & $-0.047^{* * *}$ & $(0.003)$ \\
\hline United States & $-0.048^{* * *}$ & $(0.003)$ \\
\hline Russia & $-0.126^{* * *}$ & $(0.004)$ \\
\hline China & $-0.137^{* * *}$ & $(0.003)$ \\
\hline Others & $-0.105^{* * *}$ & $(0.006)$ \\
\hline \multicolumn{3}{|l|}{ Producer } \\
\hline Own & 0.000 & (.) \\
\hline Germany & $-0.010^{*}$ & $(0.004)$ \\
\hline United States & $-0.023^{* * *}$ & $(0.004)$ \\
\hline Russia & $-0.037^{* * *}$ & $(0.004)$ \\
\hline China & $-0.074^{* * *}$ & $(0.003)$ \\
\hline Others & $-0.026^{* * *}$ & $(0.007)$ \\
\hline \multicolumn{3}{|l|}{ Duration } \\
\hline 6 months & 0.000 & (.) \\
\hline 1 year & $0.070^{* * *}$ & $(0.002)$ \\
\hline 2 years & $0.123^{* * *}$ & $(0.002)$ \\
\hline 5 years & $0.185^{* * *}$ & $(0.002)$ \\
\hline \multicolumn{3}{|l|}{ Efficacy } \\
\hline $55 \%$ & 0.000 & (.) \\
\hline $65 \%$ & $0.084^{* * *}$ & $(0.002)$ \\
\hline $75 \%$ & $0.174^{* * *}$ & $(0.002)$ \\
\hline $85 \%$ & $0.258^{* * *}$ & $(0.003)$ \\
\hline $95 \%$ & $0.339^{* * *}$ & $(0.003)$ \\
\hline \multicolumn{3}{|l|}{ Doses } \\
\hline 1 & 0.000 & (.) \\
\hline 2 & $-0.023^{* * *}$ & $(0.002)$ \\
\hline 3 & $-0.046^{* * *}$ & $(0.002)$ \\
\hline \multicolumn{3}{|l|}{ Technology } \\
\hline RNA (None) & 0.000 & (.) \\
\hline Protein subunit (Hepatitis B) & $0.042^{* * *}$ & $(0.002)$ \\
\hline Viral vector (Ebola) & $0.043^{* * *}$ & $(0.002)$ \\
\hline Whole virus (Pertussis) & $0.053^{* * *}$ & $(0.002)$ \\
\hline \multicolumn{3}{|l|}{ Endorser } \\
\hline Unspecified & 0.000 & (.) \\
\hline Government leaders & $0.036^{* * *}$ & $(0.003)$ \\
\hline Opposition leaders & $0.016^{* * *}$ & $(0.003)$ \\
\hline Leading entrepreneurs & $0.030^{* * *}$ & $(0.003)$ \\
\hline Leading entertainers & $0.010^{* * *}$ & $(0.003)$ \\
\hline Professional athletes & $0.020^{* * *}$ & $(0.003)$ \\
\hline Medical professionals & $0.086^{* * *}$ & $(0.003)$ \\
\hline Observations & 457693 & \\
\hline$R^{2}$ & 0.102 & \\
\hline
\end{tabular}


Table S5 Regression results across Nationalism (25th vs. 75th percentile split). This model is used to construct Figure 4 in the main text.

\begin{tabular}{|c|c|c|c|c|}
\hline \multirow{2}{*}{ Developer } & \multicolumn{2}{|c|}{ Low Nationalism } & \multicolumn{2}{|c|}{ High Nationalism } \\
\hline & \multicolumn{2}{|c|}{ Vaccine Choice $(0 / 1)$} & \multicolumn{2}{|c|}{ Vaccine Choice $(0 / 1)$} \\
\hline & & & & \\
\hline Own & 0.000 & (.) & 0.000 & (.) \\
\hline Germany & $-0.017^{*}$ & $(0.007)$ & $-0.063^{* * *}$ & $(0.006)$ \\
\hline United States & $-0.017^{* *}$ & $(0.007)$ & $-0.057^{* * *}$ & $(0.007)$ \\
\hline Russia & $-0.103^{* * *}$ & $(0.007)$ & $-0.121^{* * *}$ & $(0.007)$ \\
\hline China & $-0.120^{* * *}$ & $(0.006)$ & $-0.146^{* * *}$ & $(0.006)$ \\
\hline Others & $-0.056^{* *}$ & $(0.019)$ & $-0.132^{* * *}$ & $(0.010)$ \\
\hline \multicolumn{5}{|l|}{ Producer } \\
\hline Own & 0.000 & (.) & 0.000 & (.) \\
\hline Germany & 0.002 & $(0.008)$ & $-0.025^{* * *}$ & $(0.007)$ \\
\hline United States & -0.005 & $(0.008)$ & $-0.050^{* * *}$ & $(0.007)$ \\
\hline Russia & $-0.032^{* * *}$ & $(0.008)$ & $-0.055^{* * *}$ & $(0.007)$ \\
\hline China & $-0.087^{* * *}$ & $(0.006)$ & $-0.065^{* * *}$ & $(0.004)$ \\
\hline Others & $-0.049^{*}$ & $(0.022)$ & $-0.023^{*}$ & $(0.011)$ \\
\hline \multicolumn{5}{|l|}{ Duration } \\
\hline 6 months & 0.000 & (.) & 0.000 & (.) \\
\hline 1 year & $0.073^{* * *}$ & $(0.004)$ & $0.063^{* * *}$ & $(0.004)$ \\
\hline 2 years & $0.127^{* * *}$ & $(0.004)$ & $0.118^{* * *}$ & $(0.004)$ \\
\hline 5 years & $0.186^{* * *}$ & $(0.005)$ & $0.178^{* * *}$ & $(0.004)$ \\
\hline \multicolumn{5}{|l|}{ Efficacy } \\
\hline $55 \%$ & 0.000 & (.) & 0.000 & (.) \\
\hline $65 \%$ & $0.086^{* * *}$ & $(0.004)$ & $0.075^{* * *}$ & $(0.004)$ \\
\hline $75 \%$ & $0.176^{* * *}$ & $(0.005)$ & $0.159^{* * *}$ & $(0.004)$ \\
\hline $85 \%$ & $0.267^{* * *}$ & $(0.005)$ & $0.236^{* * *}$ & $(0.005)$ \\
\hline $95 \%$ & $0.350^{* * *}$ & $(0.006)$ & $0.313^{* * *}$ & $(0.005)$ \\
\hline \multicolumn{5}{|l|}{ Doses } \\
\hline 1 & 0.000 & (.) & 0.000 & (.) \\
\hline 2 & $-0.030^{* * *}$ & $(0.003)$ & $-0.020^{* * *}$ & $(0.003)$ \\
\hline 3 & $-0.051^{* * *}$ & $(0.004)$ & $-0.039^{* * *}$ & $(0.003)$ \\
\hline \multicolumn{5}{|l|}{ Technology } \\
\hline RNA (None) & 0.000 & (.) & 0.000 & (.) \\
\hline Protein subunit (Hepatitis B) & $0.049^{* * *}$ & $(0.004)$ & $0.041^{* * *}$ & $(0.004)$ \\
\hline Viral vector (Ebola) & $0.053^{* * *}$ & $(0.004)$ & $0.038^{* * *}$ & $(0.004)$ \\
\hline Whole virus (Pertussis) & $0.054^{* * *}$ & $(0.004)$ & $0.057^{* * *}$ & $(0.004)$ \\
\hline \multicolumn{5}{|l|}{ Endorser } \\
\hline Unspecified & 0.000 & (.) & 0.000 & (.) \\
\hline Government leaders & $0.034^{* * *}$ & $(0.005)$ & $0.032^{* * *}$ & $(0.005)$ \\
\hline Opposition leaders & $0.018^{* * *}$ & $(0.005)$ & 0.009 & $(0.005)$ \\
\hline Leading entrepreneurs & $0.034^{* * *}$ & $(0.005)$ & $0.029^{* * *}$ & $(0.005)$ \\
\hline Leading entertainers & $0.011^{*}$ & $(0.005)$ & 0.003 & $(0.005)$ \\
\hline Professional athletes & $0.021^{* * *}$ & $(0.005)$ & $0.019^{* * *}$ & $(0.005)$ \\
\hline Medical professionals & $0.100^{* * *}$ & $(0.006)$ & $0.075^{* * *}$ & $(0.005)$ \\
\hline Observations & 117480 & & 136102 & \\
\hline$R^{2}$ & 0.110 & & 0.090 & \\
\hline
\end{tabular}

Standard errors in parentheses

${ }^{*} p<0.05,{ }^{* *} p<0.01,{ }^{* * *} p<0.001$ 
Table S6 Regression results across Nationalism (40th vs. 60th percentile split). This model is used to construct Figure S2.

\begin{tabular}{|c|c|c|c|c|}
\hline \multirow{3}{*}{ Developer } & \multicolumn{2}{|c|}{ Low Nationalism } & \multicolumn{2}{|c|}{ High Nationalism } \\
\hline & \multicolumn{2}{|c|}{ Vaccine Choice $(0 / 1)$} & \multicolumn{2}{|c|}{ Vaccine Choice $(0 / 1)$} \\
\hline & & & & \\
\hline Own & 0.000 & (.) & 0.000 & (.) \\
\hline Germany & $-0.020^{* *}$ & $(0.006)$ & $-0.056^{* * *}$ & $(0.006)$ \\
\hline United States & $-0.026^{* * *}$ & $(0.006)$ & $-0.054^{* * *}$ & $(0.006)$ \\
\hline Russia & $-0.102^{* * *}$ & $(0.006)$ & $-0.118^{* * *}$ & $(0.006)$ \\
\hline China & $-0.113^{* * *}$ & $(0.005)$ & $-0.139^{* * *}$ & $(0.005)$ \\
\hline Others & $-0.028^{*}$ & $(0.013)$ & $-0.109^{* * *}$ & $(0.009)$ \\
\hline \multicolumn{5}{|l|}{ Producer } \\
\hline Own & 0.000 & (.) & 0.000 & (.) \\
\hline Germany & 0.000 & $(0.007)$ & $-0.020^{* *}$ & $(0.006)$ \\
\hline United States & -0.008 & $(0.007)$ & $-0.041^{* * *}$ & $(0.006)$ \\
\hline Russia & $-0.028^{* * *}$ & $(0.007)$ & $-0.047^{* * *}$ & $(0.006)$ \\
\hline China & $-0.072^{* * *}$ & $(0.005)$ & $-0.052^{* * *}$ & $(0.004)$ \\
\hline Others & $-0.040^{* *}$ & $(0.015)$ & -0.011 & $(0.010)$ \\
\hline \multicolumn{5}{|l|}{ Duration } \\
\hline 6 months & 0.000 & (.) & 0.000 & (.) \\
\hline 1 year & $0.077^{* * *}$ & (0.004) & $0.069^{* * *}$ & $(0.003)$ \\
\hline 2 years & $0.130^{* * *}$ & (0.004) & $0.123^{* * *}$ & $(0.003)$ \\
\hline 5 years & $0.194^{* * *}$ & $(0.004)$ & $0.189^{* * *}$ & $(0.004)$ \\
\hline \multicolumn{5}{|l|}{ Efficacy } \\
\hline $55 \%$ & 0.000 & (.) & 0.000 & (.) \\
\hline $65 \%$ & $0.089^{* * *}$ & $(0.004)$ & $0.080^{* * *}$ & $(0.003)$ \\
\hline $75 \%$ & $0.182^{* * *}$ & (0.004) & $0.170^{* * *}$ & (0.004) \\
\hline $85 \%$ & $0.271^{* * *}$ & (0.004) & $0.252^{* * *}$ & $(0.004)$ \\
\hline $95 \%$ & $0.354^{* * *}$ & $(0.005)$ & $0.333^{* * *}$ & $(0.004)$ \\
\hline \multicolumn{5}{|l|}{ Doses } \\
\hline 1 & 0.000 & (.) & 0.000 & (.) \\
\hline 2 & $-0.029^{* * *}$ & $(0.003)$ & $-0.020^{* * *}$ & $(0.003)$ \\
\hline 3 & $-0.051^{* * *}$ & $(0.003)$ & $-0.045^{* * *}$ & $(0.003)$ \\
\hline \multicolumn{5}{|l|}{ Technology } \\
\hline RNA (None) & 0.000 & (.) & 0.000 & (.) \\
\hline Protein subunit (Hepatitis B) & $0.045^{* * *}$ & (0.004) & $0.037^{* * *}$ & $(0.003)$ \\
\hline Viral vector (Ebola) & $0.047^{* * *}$ & $(0.004)$ & $0.034^{* * *}$ & $(0.003)$ \\
\hline Whole virus (Pertussis) & $0.055^{* * *}$ & $(0.004)$ & $0.053^{* * *}$ & $(0.003)$ \\
\hline \multicolumn{5}{|l|}{ Endorser } \\
\hline Unspecified & 0.000 & (.) & 0.000 & (.) \\
\hline Government leaders & $0.035^{* * *}$ & $(0.005)$ & $0.028^{* * *}$ & $(0.004)$ \\
\hline Opposition leaders & $0.018^{* * *}$ & $(0.004)$ & 0.008 & $(0.004)$ \\
\hline Leading entrepreneurs & $0.029^{* * *}$ & $(0.004)$ & $0.027^{* * *}$ & $(0.004)$ \\
\hline Leading entertainers & $0.012^{* *}$ & $(0.004)$ & 0.005 & $(0.004)$ \\
\hline Professional athletes & $0.019^{* * *}$ & $(0.004)$ & $0.015^{* * *}$ & $(0.004)$ \\
\hline Medical professionals & $0.097^{* * *}$ & $(0.005)$ & $0.076^{* * *}$ & $(0.004)$ \\
\hline Observations & 160891 & & 197639 & \\
\hline$R^{2}$ & 0.108 & & 0.097 & \\
\hline
\end{tabular}


Table S7 Regression results across Nationalism (30th vs. 70th percentile split). This model is used to construct Figure S3.

\begin{tabular}{|c|c|c|c|c|}
\hline \multirow{2}{*}{$\begin{array}{l}\text { Developer } \\
\end{array}$} & \multicolumn{2}{|c|}{ Low Nationalism } & \multicolumn{2}{|c|}{ High Nationalism } \\
\hline & \multicolumn{2}{|c|}{ Vaccine Choice $(0 / 1)$} & \multicolumn{2}{|c|}{ Vaccine Choice $(0 / 1)$} \\
\hline Own & 0000 & () & 0000 & () \\
\hline Germany & $-0.019^{* *}$ & $(0.006)$ & $-0.063^{* * *}$ & $(0.006)$ \\
\hline United States & $-0.023^{* * *}$ & $(0.006)$ & $-0.057^{* * *}$ & $(0.007)$ \\
\hline Russia & $-0.103^{* * *}$ & $(0.007)$ & $-0.121^{* * *}$ & $(0.007)$ \\
\hline China & $-0.113^{* * *}$ & $(0.006)$ & $-0.146^{* * *}$ & $(0.006)$ \\
\hline Others & -0.030 & $(0.015)$ & $-0.132^{* * *}$ & $(0.010)$ \\
\hline \multicolumn{5}{|l|}{ Producer } \\
\hline Own & 0.000 & (.) & 0.000 & (.) \\
\hline Germany & 0.001 & $(0.008)$ & $-0.025^{* * *}$ & $(0.007)$ \\
\hline United States & -0.007 & $(0.008)$ & $-0.050^{* * *}$ & $(0.007)$ \\
\hline Russia & $-0.028^{* * *}$ & $(0.008)$ & $-0.055^{* * *}$ & $(0.007)$ \\
\hline China & $-0.076^{* * *}$ & $(0.005)$ & $-0.065^{* * *}$ & $(0.004)$ \\
\hline Others & $-0.045^{* *}$ & $(0.017)$ & $-0.023^{*}$ & $(0.011)$ \\
\hline \multicolumn{5}{|l|}{ Duration } \\
\hline 6 months & 0.000 & (.) & 0.000 & (.) \\
\hline 1 year & $0.077^{* * *}$ & $(0.004)$ & $0.063^{* * *}$ & $(0.004)$ \\
\hline 2 years & $0.130^{* * *}$ & $(0.004)$ & $0.118^{* * *}$ & $(0.004)$ \\
\hline 5 years & $0.193^{* * *}$ & $(0.004)$ & $0.178^{* * *}$ & $(0.004)$ \\
\hline \multicolumn{5}{|l|}{ Efficacy } \\
\hline $55 \%$ & 0.000 & (.) & 0.000 & (.) \\
\hline $65 \%$ & $0.087^{* * *}$ & $(0.004)$ & $0.075^{* * *}$ & $(0.004)$ \\
\hline $75 \%$ & $0.179^{* * *}$ & $(0.004)$ & $0.159^{* * *}$ & $(0.004)$ \\
\hline $85 \%$ & $0.269^{* * *}$ & $(0.005)$ & $0.236^{* * *}$ & $(0.005)$ \\
\hline $95 \%$ & $0.353^{* * *}$ & $(0.005)$ & $0.313^{* * *}$ & $(0.005)$ \\
\hline \multicolumn{5}{|l|}{ Doses } \\
\hline 1 & 0.000 & (.) & 0.000 & (.) \\
\hline 2 & $-0.030^{* * *}$ & $(0.003)$ & $-0.020^{* * *}$ & $(0.003)$ \\
\hline 3 & $-0.054^{* * *}$ & $(0.003)$ & $-0.039^{* * *}$ & $(0.003)$ \\
\hline \multicolumn{5}{|l|}{ Technology } \\
\hline RNA (None) & 0.000 & (.) & 0.000 & (.) \\
\hline Protein subunit (Hepatitis B) & $0.045^{* * *}$ & $(0.004)$ & $0.041^{* * *}$ & $(0.004)$ \\
\hline Viral vector (Ebola) & $0.048^{* * *}$ & $(0.004)$ & $0.038^{* * *}$ & $(0.004)$ \\
\hline Whole virus (Pertussis) & $0.054^{* * *}$ & $(0.004)$ & $0.057^{* * *}$ & $(0.004)$ \\
\hline \multicolumn{5}{|l|}{ Endorser } \\
\hline Unspecified & 0.000 & (.) & 0.000 & (.) \\
\hline Government leaders & $0.033^{* * *}$ & $(0.005)$ & $0.032^{* * *}$ & $(0.005)$ \\
\hline Opposition leaders & $0.017^{* * *}$ & $(0.005)$ & 0.009 & $(0.005)$ \\
\hline Leading entrepreneurs & $0.031^{* * *}$ & $(0.005)$ & $0.029^{* * *}$ & $(0.005)$ \\
\hline Leading entertainers & $0.010^{*}$ & $(0.005)$ & 0.003 & $(0.005)$ \\
\hline Professional athletes & $0.018^{* * *}$ & $(0.005)$ & $0.019^{* * *}$ & $(0.005)$ \\
\hline Medical professionals & $0.099^{* * *}$ & $(0.005)$ & $0.075^{* * *}$ & $(0.005)$ \\
\hline Observations & 144717 & & 136102 & \\
\hline$R^{2}$ & 0.109 & & 0.090 & \\
\hline
\end{tabular}


Table S8 Regression results across Nationalism (20th vs. 80th percentile split). This model is used to construct Figure S4.

\begin{tabular}{|c|c|c|c|c|}
\hline \multirow{2}{*}{ Develoner } & \multicolumn{2}{|c|}{ Low Nationalism } & \multicolumn{2}{|c|}{ High Nationalism } \\
\hline & \multicolumn{2}{|c|}{ Vaccine Choice $(0 / 1)$} & \multicolumn{2}{|c|}{ Vaccine Choice $(0 / 1)$} \\
\hline Own & م000 & () & م ח०० & () \\
\hline Germany & $-0.017^{*}$ & $(0.007)$ & $-0.069^{* * *}$ & $(0.007)$ \\
\hline United States & $-0.018^{*}$ & $(0.007)$ & $-0.064^{* * *}$ & $(0.007)$ \\
\hline Russia & $-0.105^{* * *}$ & $(0.007)$ & $-0.125^{* * *}$ & $(0.007)$ \\
\hline China & $-0.126^{* * *}$ & $(0.007)$ & $-0.150^{* * *}$ & $(0.007)$ \\
\hline Others & $-0.057^{* *}$ & $(0.021)$ & $-0.142^{* * *}$ & $(0.011)$ \\
\hline \multicolumn{5}{|l|}{ Producer } \\
\hline Own & 0.000 & (.) & 0.000 & (.) \\
\hline Germany & 0.005 & (0.009) & $-0.025^{* *}$ & $(0.008)$ \\
\hline United States & -0.004 & $(0.008)$ & $-0.046^{* * *}$ & $(0.008)$ \\
\hline Russia & $-0.032^{* * *}$ & (0.009) & $-0.054^{* * *}$ & $(0.008)$ \\
\hline China & $-0.090^{* * *}$ & $(0.006)$ & $-0.070^{* * *}$ & $(0.004)$ \\
\hline Others & $-0.062^{* *}$ & $(0.024)$ & $-0.034^{* *}$ & $(0.012)$ \\
\hline \multicolumn{5}{|l|}{ Duration } \\
\hline 6 months & 0.000 & (.) & 0.000 & (.) \\
\hline 1 year & $0.072^{* * *}$ & $(0.004)$ & $0.060^{* * *}$ & $(0.004)$ \\
\hline 2 years & $0.124^{* * *}$ & $(0.005)$ & $0.116^{* * *}$ & $(0.004)$ \\
\hline 5 years & $0.186^{* * *}$ & $(0.005)$ & $0.172^{* * *}$ & $(0.005)$ \\
\hline \multicolumn{5}{|l|}{ Efficacy } \\
\hline $55 \%$ & 0.000 & (.) & 0.000 & (.) \\
\hline $65 \%$ & $0.084^{* * *}$ & $(0.005)$ & $0.075^{* * *}$ & $(0.005)$ \\
\hline $75 \%$ & $0.172^{* * *}$ & $(0.005)$ & $0.158^{* * *}$ & $(0.005)$ \\
\hline $85 \%$ & $0.263^{* * *}$ & $(0.005)$ & $0.234^{* * *}$ & $(0.005)$ \\
\hline $95 \%$ & $0.347^{* * *}$ & $(0.006)$ & $0.309^{* * *}$ & $(0.006)$ \\
\hline \multicolumn{5}{|l|}{ Doses } \\
\hline 1 & 0.000 & (.) & 0.000 & (.) \\
\hline 2 & $-0.030^{* * *}$ & $(0.004)$ & $-0.017^{* * *}$ & $(0.004)$ \\
\hline 3 & $-0.050^{* * *}$ & $(0.004)$ & $-0.033^{* * *}$ & $(0.004)$ \\
\hline \multicolumn{5}{|l|}{ Technology } \\
\hline RNA (None) & 0.000 & (.) & 0.000 & (.) \\
\hline Protein subunit (Hepatitis B) & $0.050^{* * *}$ & $(0.004)$ & $0.043^{* * *}$ & $(0.004)$ \\
\hline Viral vector (Ebola) & $0.055^{* * *}$ & $(0.005)$ & $0.038^{* * *}$ & $(0.004)$ \\
\hline Whole virus (Pertussis) & $0.053^{* * *}$ & $(0.005)$ & $0.055^{* * *}$ & $(0.004)$ \\
\hline \multicolumn{5}{|l|}{ Endorser } \\
\hline Unspecified & 0.000 & (.) & 0.000 & (.) \\
\hline Government leaders & $0.036^{* * *}$ & $(0.006)$ & $0.038^{* * *}$ & $(0.005)$ \\
\hline Opposition leaders & $0.022^{* * *}$ & $(0.005)$ & $0.012^{*}$ & $(0.006)$ \\
\hline Leading entrepreneurs & $0.037^{* * *}$ & $(0.005)$ & $0.035^{* * *}$ & $(0.005)$ \\
\hline Leading entertainers & $0.015^{* *}$ & $(0.005)$ & 0.007 & $(0.005)$ \\
\hline Professional athletes & $0.024^{* * *}$ & $(0.005)$ & $0.023^{* * *}$ & $(0.005)$ \\
\hline Medical professionals & $0.101^{* * *}$ & $(0.006)$ & $0.077^{* * *}$ & $(0.006)$ \\
\hline Observations & 109367 & & 111541 & \\
\hline$R^{2}$ & 0.110 & & 0.088 & \\
\hline
\end{tabular}


Table S9 Regression results for male respondents. This model is used to construct Figure S5.

\begin{tabular}{|c|c|c|}
\hline \multirow{2}{*}{ Developer } & \multicolumn{2}{|c|}{$\begin{array}{c}(1) \\
\text { Vaccine Choice }(0 / 1)\end{array}$} \\
\hline & & \\
\hline Own & 0.000 & (.) \\
\hline Germany & $-0.043^{* * *}$ & $(0.005)$ \\
\hline United States & $-0.047^{* * *}$ & $(0.005)$ \\
\hline Russia & $-0.127^{* * *}$ & $(0.005)$ \\
\hline China & $-0.135^{* * *}$ & $(0.005)$ \\
\hline Others & $-0.115^{* * *}$ & $(0.009)$ \\
\hline \multicolumn{3}{|l|}{ Producer } \\
\hline Own & 0.000 & (.) \\
\hline Germany & -0.009 & $(0.006)$ \\
\hline United States & $-0.014^{*}$ & $(0.006)$ \\
\hline Russia & $-0.039^{* * *}$ & $(0.006)$ \\
\hline China & $-0.075^{* * *}$ & $(0.004)$ \\
\hline Others & -0.017 & $(0.010)$ \\
\hline \multicolumn{3}{|l|}{ Duration } \\
\hline 6 months & 0.000 & (.) \\
\hline 1 year & $0.067^{* * *}$ & $(0.003)$ \\
\hline 2 years & $0.122^{* * *}$ & $(0.003)$ \\
\hline 5 years & $0.182^{* * *}$ & $(0.003)$ \\
\hline \multicolumn{3}{|l|}{ Efficacy } \\
\hline $55 \%$ & 0.000 & (.) \\
\hline $65 \%$ & $0.086^{* * *}$ & $(0.003)$ \\
\hline $75 \%$ & $0.174^{* * *}$ & $(0.003)$ \\
\hline $85 \%$ & $0.258^{* * *}$ & $(0.004)$ \\
\hline $95 \%$ & $0.336^{* * *}$ & $(0.004)$ \\
\hline \multicolumn{3}{|l|}{ Doses } \\
\hline 1 & 0.000 & (.) \\
\hline 2 & $-0.029^{* * *}$ & $(0.003)$ \\
\hline 3 & $-0.048^{* * *}$ & $(0.003)$ \\
\hline \multicolumn{3}{|l|}{ Technology } \\
\hline RNA (None) & 0.000 & (.) \\
\hline Protein subunit (Hepatitis B) & $0.034^{* * *}$ & $(0.003)$ \\
\hline Viral vector (Ebola) & $0.032^{* * *}$ & $(0.003)$ \\
\hline Whole virus (Pertussis) & $0.039^{* * *}$ & $(0.003)$ \\
\hline \multicolumn{3}{|l|}{ Endorser } \\
\hline Unspecified & 0.000 & (.) \\
\hline Government leaders & $0.029^{* * *}$ & $(0.004)$ \\
\hline Opposition leaders & $0.013^{* * *}$ & $(0.004)$ \\
\hline Leading entrepreneurs & $0.028^{* * *}$ & $(0.004)$ \\
\hline Leading entertainers & 0.006 & $(0.004)$ \\
\hline Professional athletes & $0.015^{* * *}$ & $(0.004)$ \\
\hline Medical professionals & $0.074^{* * *}$ & $(0.004)$ \\
\hline Observations & 226478 & \\
\hline$R^{2}$ & 0.100 & \\
\hline
\end{tabular}


Table S10 Regression results for female respondents. This model is used to construct Figure S5.

\begin{tabular}{|c|c|c|}
\hline \multirow{2}{*}{ Developer } & \multicolumn{2}{|c|}{$\begin{array}{c}(1) \\
\text { Vaccine Choice }(0 / 1)\end{array}$} \\
\hline & & \\
\hline Own & 0.000 & (.) \\
\hline Germany & $-0.051^{* * *}$ & $(0.005)$ \\
\hline United States & $-0.050^{* * *}$ & $(0.005)$ \\
\hline Russia & $-0.125^{* * *}$ & $(0.005)$ \\
\hline China & $-0.138^{* * *}$ & $(0.004)$ \\
\hline Others & $-0.096^{* * *}$ & $(0.009)$ \\
\hline \multicolumn{3}{|l|}{ Producer } \\
\hline Own & 0.000 & (.) \\
\hline Germany & $-0.011^{*}$ & $(0.006)$ \\
\hline United States & $-0.031^{* * *}$ & $(0.006)$ \\
\hline Russia & $-0.034^{* * *}$ & $(0.006)$ \\
\hline China & $-0.074^{* * *}$ & $(0.004)$ \\
\hline Others & $-0.035^{* *}$ & $(0.011)$ \\
\hline \multicolumn{3}{|l|}{ Duration } \\
\hline 6 months & 0.000 & (.) \\
\hline 1 year & $0.073^{* * *}$ & $(0.003)$ \\
\hline 2 years & $0.125^{* * *}$ & $(0.003)$ \\
\hline 5 years & $0.188^{* * *}$ & $(0.003)$ \\
\hline \multicolumn{3}{|l|}{ Efficacy } \\
\hline $55 \%$ & 0.000 & (.) \\
\hline $65 \%$ & $0.082^{* * *}$ & $(0.003)$ \\
\hline $75 \%$ & $0.174^{* * *}$ & $(0.003)$ \\
\hline $85 \%$ & $0.258^{* * *}$ & $(0.004)$ \\
\hline $95 \%$ & $0.343^{* * *}$ & $(0.004)$ \\
\hline \multicolumn{3}{|l|}{ Doses } \\
\hline 1 & 0.000 & (.) \\
\hline 2 & $-0.018^{* * *}$ & $(0.002)$ \\
\hline 3 & $-0.044^{* * *}$ & $(0.003)$ \\
\hline \multicolumn{3}{|l|}{ Technology } \\
\hline RNA (None) & 0.000 & (.) \\
\hline Protein subunit (Hepatitis B) & $0.051^{* * *}$ & $(0.003)$ \\
\hline Viral vector (Ebola) & $0.054^{* * *}$ & $(0.003)$ \\
\hline Whole virus (Pertussis) & $0.066^{* * *}$ & $(0.003)$ \\
\hline \multicolumn{3}{|l|}{ Endorser } \\
\hline Unspecified & 0.000 & (.) \\
\hline Government leaders & $0.042^{* * *}$ & $(0.004)$ \\
\hline Opposition leaders & $0.019^{* * *}$ & $(0.004)$ \\
\hline Leading entrepreneurs & $0.033^{* * *}$ & $(0.004)$ \\
\hline Leading entertainers & $0.014^{* * *}$ & $(0.004)$ \\
\hline Professional athletes & $0.024^{* * *}$ & $(0.004)$ \\
\hline Medical professionals & $0.098^{* * *}$ & $(0.004)$ \\
\hline Observations & 231215 & \\
\hline$R^{2}$ & 0.104 & \\
\hline
\end{tabular}


Table S11 Regression results for the age group 18-24. This model is used to construct Figure S6.

\begin{tabular}{|c|c|c|}
\hline \multirow{2}{*}{ Developer } & \multicolumn{2}{|c|}{$\begin{array}{c}(1) \\
\text { Vaccine Choice }(0 / 1)\end{array}$} \\
\hline & & \\
\hline Own & 0.000 & (.) \\
\hline Germany & $-0.032^{* *}$ & $(0.010)$ \\
\hline United States & -0.019 & $(0.010)$ \\
\hline Russia & $-0.057^{* * *}$ & $(0.010)$ \\
\hline China & $-0.080^{* * *}$ & $(0.009)$ \\
\hline Others & $-0.063^{* * *}$ & $(0.018)$ \\
\hline \multicolumn{3}{|l|}{ Producer } \\
\hline Own & 0.000 & (.) \\
\hline Germany & -0.023 & $(0.012)$ \\
\hline United States & $-0.054^{* * *}$ & $(0.012)$ \\
\hline Russia & $-0.042^{* * *}$ & $(0.012)$ \\
\hline China & $-0.064^{* * *}$ & $(0.007)$ \\
\hline Others & $-0.064^{* *}$ & $(0.021)$ \\
\hline \multicolumn{3}{|l|}{ Duration } \\
\hline 6 months & 0.000 & (.) \\
\hline 1 year & $0.071^{* * *}$ & $(0.006)$ \\
\hline 2 years & $0.110^{* * *}$ & $(0.006)$ \\
\hline 5 years & $0.181^{* * *}$ & $(0.007)$ \\
\hline \multicolumn{3}{|l|}{ Efficacy } \\
\hline $55 \%$ & 0.000 & (.) \\
\hline $65 \%$ & $0.091^{* * *}$ & $(0.007)$ \\
\hline $75 \%$ & $0.178^{* * *}$ & $(0.007)$ \\
\hline $85 \%$ & $0.269^{* * *}$ & $(0.008)$ \\
\hline $95 \%$ & $0.354^{* * *}$ & $(0.008)$ \\
\hline \multicolumn{3}{|l|}{ Doses } \\
\hline 1 & 0.000 & (.) \\
\hline 2 & $-0.027^{* * *}$ & $(0.005)$ \\
\hline 3 & $-0.039^{* * *}$ & $(0.005)$ \\
\hline \multicolumn{3}{|l|}{ Technology } \\
\hline RNA (None) & 0.000 & (.) \\
\hline Protein subunit (Hepatitis B) & $0.051^{* * *}$ & $(0.006)$ \\
\hline Viral vector (Ebola) & $0.046^{* * *}$ & $(0.006)$ \\
\hline Whole virus (Pertussis) & $0.063^{* * *}$ & $(0.006)$ \\
\hline \multicolumn{3}{|l|}{ Endorser } \\
\hline Unspecified & 0.000 & (.) \\
\hline Government leaders & $0.044^{* * *}$ & $(0.008)$ \\
\hline Opposition leaders & 0.010 & $(0.008)$ \\
\hline Leading entrepreneurs & $0.031^{* * *}$ & $(0.008)$ \\
\hline Leading entertainers & 0.007 & $(0.008)$ \\
\hline Professional athletes & $0.017^{*}$ & $(0.008)$ \\
\hline Medical professionals & $0.102^{* * *}$ & $(0.008)$ \\
\hline Observations & 53232 & \\
\hline$R^{2}$ & 0.095 & \\
\hline
\end{tabular}


Table S12 Regression results for the age group 25-34. This model is used to construct Figure S6.

\begin{tabular}{|c|c|c|}
\hline \multirow{2}{*}{ Developer } & \multicolumn{2}{|c|}{$\begin{array}{c}(1) \\
\text { Vaccine Choice }(0 / 1)\end{array}$} \\
\hline & & \\
\hline Own & 0.000 & (.) \\
\hline Germany & $-0.042^{* * *}$ & $(0.008)$ \\
\hline United States & $-0.042^{* * *}$ & $(0.008)$ \\
\hline Russia & $-0.102^{* * *}$ & $(0.008)$ \\
\hline China & $-0.117^{* * *}$ & $(0.007)$ \\
\hline Others & $-0.093^{* * *}$ & $(0.017)$ \\
\hline \multicolumn{3}{|l|}{ Producer } \\
\hline Own & 0.000 & (.) \\
\hline Germany & -0.010 & $(0.009)$ \\
\hline United States & -0.008 & $(0.009)$ \\
\hline Russia & $-0.029^{* *}$ & $(0.009)$ \\
\hline China & $-0.080^{* * *}$ & $(0.006)$ \\
\hline Others & -0.027 & $(0.020)$ \\
\hline \multicolumn{3}{|l|}{ Duration } \\
\hline 6 months & 0.000 & (.) \\
\hline 1 year & $0.068^{* * *}$ & $(0.005)$ \\
\hline 2 years & $0.116^{* * *}$ & $(0.005)$ \\
\hline 5 years & $0.173^{* * *}$ & $(0.005)$ \\
\hline \multicolumn{3}{|l|}{ Efficacy } \\
\hline $55 \%$ & 0.000 & (.) \\
\hline $65 \%$ & $0.083^{* * *}$ & $(0.005)$ \\
\hline $75 \%$ & $0.177^{* * *}$ & $(0.005)$ \\
\hline $85 \%$ & $0.258^{* * *}$ & $(0.006)$ \\
\hline $95 \%$ & $0.334^{* * *}$ & $(0.006)$ \\
\hline \multicolumn{3}{|l|}{ Doses } \\
\hline 1 & 0.000 & (.) \\
\hline 2 & $-0.015^{* * *}$ & $(0.004)$ \\
\hline 3 & $-0.037^{* * *}$ & $(0.004)$ \\
\hline \multicolumn{3}{|l|}{ Technology } \\
\hline RNA (None) & 0.000 & (.) \\
\hline Protein subunit (Hepatitis B) & $0.049^{* * *}$ & $(0.005)$ \\
\hline Viral vector (Ebola) & $0.050^{* * *}$ & $(0.005)$ \\
\hline Whole virus (Pertussis) & $0.060^{* * *}$ & $(0.005)$ \\
\hline \multicolumn{3}{|l|}{ Endorser } \\
\hline Unspecified & 0.000 & (.) \\
\hline Government leaders & $0.044^{* * *}$ & $(0.006)$ \\
\hline Opposition leaders & $0.024^{* * *}$ & $(0.006)$ \\
\hline Leading entrepreneurs & $0.035^{* * *}$ & $(0.006)$ \\
\hline Leading entertainers & $0.022^{* * *}$ & $(0.006)$ \\
\hline Professional athletes & $0.033^{* * *}$ & $(0.006)$ \\
\hline Medical professionals & $0.111^{* * *}$ & $(0.006)$ \\
\hline Observations & 89814 & \\
\hline$R^{2}$ & 0.097 & \\
\hline
\end{tabular}


Table S13 Regression results for the age group 35-44. This model is used to construct Figure S6.

\begin{tabular}{|c|c|c|}
\hline \multirow{2}{*}{ Developer } & \multicolumn{2}{|c|}{$\begin{array}{c}(1) \\
\text { Vaccine Choice }(0 / 1)\end{array}$} \\
\hline & & \\
\hline Own & 0.000 & (.) \\
\hline Germany & $-0.037^{* * *}$ & $(0.008)$ \\
\hline United States & $-0.045^{* * *}$ & $(0.008)$ \\
\hline Russia & $-0.113^{* * *}$ & $(0.008)$ \\
\hline China & $-0.124^{* * *}$ & $(0.007)$ \\
\hline Others & $-0.145^{* * *}$ & $(0.015)$ \\
\hline \multicolumn{3}{|l|}{ Producer } \\
\hline Own & 0.000 & (.) \\
\hline Germany & $-0.018^{*}$ & $(0.009)$ \\
\hline United States & $-0.030^{* * *}$ & $(0.009)$ \\
\hline Russia & $-0.036^{* * *}$ & $(0.009)$ \\
\hline China & $-0.095^{* * *}$ & $(0.006)$ \\
\hline Others & $-0.040^{*}$ & $(0.017)$ \\
\hline \multicolumn{3}{|l|}{ Duration } \\
\hline 6 months & 0.000 & (.) \\
\hline 1 year & $0.061^{* * *}$ & $(0.005)$ \\
\hline 2 years & $0.118^{* * *}$ & $(0.005)$ \\
\hline 5 years & $0.175^{* * *}$ & $(0.005)$ \\
\hline \multicolumn{3}{|l|}{ Efficacy } \\
\hline $55 \%$ & 0.000 & (.) \\
\hline $65 \%$ & $0.085^{* * *}$ & $(0.005)$ \\
\hline $75 \%$ & $0.171^{* * *}$ & $(0.006)$ \\
\hline $85 \%$ & $0.256^{* * *}$ & $(0.006)$ \\
\hline $95 \%$ & $0.335^{* * *}$ & $(0.006)$ \\
\hline \multicolumn{3}{|l|}{ Doses } \\
\hline 1 & 0.000 & (.) \\
\hline 2 & $-0.020^{* * *}$ & $(0.004)$ \\
\hline 3 & $-0.039^{* * *}$ & $(0.004)$ \\
\hline \multicolumn{3}{|l|}{ Technology } \\
\hline RNA (None) & 0.000 & (.) \\
\hline Protein subunit (Hepatitis B) & $0.047^{* * *}$ & $(0.005)$ \\
\hline Viral vector (Ebola) & $0.057^{* * *}$ & $(0.005)$ \\
\hline Whole virus (Pertussis) & $0.059^{* * *}$ & $(0.005)$ \\
\hline \multicolumn{3}{|l|}{ Endorser } \\
\hline Unspecified & 0.000 & (.) \\
\hline Government leaders & $0.029^{* * *}$ & $(0.006)$ \\
\hline Opposition leaders & $0.020^{* *}$ & $(0.006)$ \\
\hline Leading entrepreneurs & $0.039^{* * *}$ & $(0.006)$ \\
\hline Leading entertainers & 0.002 & $(0.006)$ \\
\hline Professional athletes & $0.021^{* * *}$ & $(0.006)$ \\
\hline Medical professionals & $0.074^{* * *}$ & $(0.006)$ \\
\hline Observations & 92467 & \\
\hline$R^{2}$ & 0.099 & \\
\hline
\end{tabular}


Table S14 Regression results for the age group 45-54. This model is used to construct Figure S6.

\begin{tabular}{|c|c|c|}
\hline \multirow{2}{*}{ Developer } & \multicolumn{2}{|c|}{$\begin{array}{c}(1) \\
\text { Vaccine Choice }(0 / 1)\end{array}$} \\
\hline & & \\
\hline Own & 0.000 & (.) \\
\hline Germany & $-0.049^{* * *}$ & $(0.008)$ \\
\hline United States & $-0.054^{* * *}$ & $(0.007)$ \\
\hline Russia & $-0.135^{* * *}$ & $(0.008)$ \\
\hline China & $-0.148^{* * *}$ & $(0.007)$ \\
\hline Others & $-0.115^{* * *}$ & $(0.015)$ \\
\hline \multicolumn{3}{|l|}{ Producer } \\
\hline Own & 0.000 & (.) \\
\hline Germany & -0.006 & $(0.009)$ \\
\hline United States & $-0.018^{*}$ & $(0.009)$ \\
\hline Russia & $-0.049^{* * *}$ & $(0.009)$ \\
\hline China & $-0.079^{* * *}$ & $(0.006)$ \\
\hline Others & -0.033 & $(0.017)$ \\
\hline \multicolumn{3}{|l|}{ Duration } \\
\hline 6 months & 0.000 & (.) \\
\hline 1 year & $0.078^{* * *}$ & $(0.005)$ \\
\hline 2 years & $0.129^{* * *}$ & $(0.005)$ \\
\hline 5 years & $0.187^{* * *}$ & $(0.005)$ \\
\hline \multicolumn{3}{|l|}{ Efficacy } \\
\hline $55 \%$ & 0.000 & (.) \\
\hline $65 \%$ & $0.085^{* * *}$ & $(0.005)$ \\
\hline $75 \%$ & $0.171^{* * *}$ & $(0.005)$ \\
\hline $85 \%$ & $0.256^{* * *}$ & $(0.006)$ \\
\hline $95 \%$ & $0.342^{* * *}$ & $(0.006)$ \\
\hline \multicolumn{3}{|l|}{ Doses } \\
\hline 1 & 0.000 & (.) \\
\hline 2 & $-0.028^{* * *}$ & $(0.004)$ \\
\hline 3 & $-0.055^{* * *}$ & $(0.004)$ \\
\hline \multicolumn{3}{|l|}{ Technology } \\
\hline RNA (None) & 0.000 & (.) \\
\hline Protein subunit (Hepatitis B) & $0.043^{* * *}$ & $(0.005)$ \\
\hline Viral vector (Ebola) & $0.043^{* * *}$ & $(0.005)$ \\
\hline Whole virus (Pertussis) & $0.050^{* * *}$ & $(0.005)$ \\
\hline \multicolumn{3}{|l|}{ Endorser } \\
\hline Unspecified & 0.000 & (.) \\
\hline Government leaders & $0.040^{* * *}$ & $(0.006)$ \\
\hline Opposition leaders & $0.019^{* *}$ & $(0.006)$ \\
\hline Leading entrepreneurs & $0.024^{* * *}$ & $(0.006)$ \\
\hline Leading entertainers & $0.016^{* *}$ & $(0.006)$ \\
\hline Professional athletes & 0.011 & $(0.006)$ \\
\hline Medical professionals & $0.080^{* * *}$ & $(0.006)$ \\
\hline Observations & 90309 & \\
\hline$R^{2}$ & 0.106 & \\
\hline
\end{tabular}


Table S15 Regression results for the age group 55-64. This model is used to construct Figure S6.

\begin{tabular}{|c|c|c|}
\hline \multirow{2}{*}{ Developer } & \multicolumn{2}{|c|}{$\begin{array}{c}(1) \\
\text { Vaccine Choice }(0 / 1)\end{array}$} \\
\hline & & \\
\hline Own & 0.000 & (.) \\
\hline Germany & $-0.063^{* * *}$ & $(0.008)$ \\
\hline United States & $-0.061^{* * *}$ & $(0.008)$ \\
\hline Russia & $-0.167^{* * *}$ & $(0.009)$ \\
\hline China & $-0.173^{* * *}$ & $(0.008)$ \\
\hline Others & $-0.142^{* * *}$ & $(0.013)$ \\
\hline \multicolumn{3}{|l|}{ Producer } \\
\hline Own & 0.000 & (.) \\
\hline Germany & 0.006 & $(0.009)$ \\
\hline United States & -0.014 & $(0.010)$ \\
\hline Russia & $-0.021^{*}$ & $(0.009)$ \\
\hline China & $-0.059^{* * *}$ & $(0.006)$ \\
\hline Others & 0.015 & $(0.015)$ \\
\hline \multicolumn{3}{|l|}{ Duration } \\
\hline 6 months & 0.000 & (.) \\
\hline 1 year & $0.070^{* * *}$ & $(0.005)$ \\
\hline 2 years & $0.130^{* * *}$ & $(0.005)$ \\
\hline 5 years & $0.199^{* * *}$ & $(0.006)$ \\
\hline \multicolumn{3}{|l|}{ Efficacy } \\
\hline $55 \%$ & 0.000 & (.) \\
\hline $65 \%$ & $0.083^{* * *}$ & $(0.005)$ \\
\hline $75 \%$ & $0.175^{* * *}$ & $(0.006)$ \\
\hline $85 \%$ & $0.258^{* * *}$ & $(0.006)$ \\
\hline $95 \%$ & $0.332^{* * *}$ & $(0.007)$ \\
\hline \multicolumn{3}{|l|}{ Doses } \\
\hline 1 & 0.000 & (.) \\
\hline 2 & $-0.032^{* * *}$ & $(0.004)$ \\
\hline 3 & $-0.054^{* * *}$ & $(0.004)$ \\
\hline \multicolumn{3}{|l|}{ Technology } \\
\hline RNA (None) & 0.000 & (.) \\
\hline Protein subunit (Hepatitis B) & $0.036^{* * *}$ & $(0.005)$ \\
\hline Viral vector (Ebola) & $0.032^{* * *}$ & $(0.005)$ \\
\hline Whole virus (Pertussis) & $0.044^{* * *}$ & $(0.005)$ \\
\hline \multicolumn{3}{|l|}{ Endorser } \\
\hline Unspecified & 0.000 & (.) \\
\hline Government leaders & $0.036^{* * *}$ & $(0.007)$ \\
\hline Opposition leaders & 0.008 & $(0.007)$ \\
\hline Leading entrepreneurs & $0.029^{* * *}$ & $(0.007)$ \\
\hline Leading entertainers & 0.003 & $(0.007)$ \\
\hline Professional athletes & $0.018^{* *}$ & $(0.007)$ \\
\hline Medical professionals & $0.067^{* * *}$ & $(0.007)$ \\
\hline Observations & 76215 & \\
\hline$R^{2}$ & 0.107 & \\
\hline
\end{tabular}


Table S16 Regression results for the age group 65+. This model is used to construct Figure S6.

(1)

Vaccine Choice $(0 / 1)$

\begin{tabular}{|c|c|c|}
\hline Developer & & \\
\hline Own & 0.000 & (.) \\
\hline Germany & $-0.053^{* * *}$ & $(0.012)$ \\
\hline United States & $-0.058^{* * *}$ & $(0.012)$ \\
\hline Russia & $-0.182^{* * *}$ & $(0.012)$ \\
\hline China & $-0.177^{* * *}$ & $(0.010)$ \\
\hline Others & -0.028 & $(0.018)$ \\
\hline Producer & & \\
\hline Own & 0.000 & (.) \\
\hline Germany & -0.025 & $(0.014)$ \\
\hline United States & $-0.038^{* *}$ & $(0.014)$ \\
\hline Russia & $-0.045^{* * *}$ & $(0.013)$ \\
\hline China & $-0.061^{* * *}$ & $(0.009)$ \\
\hline Others & $-0.055^{*}$ & $(0.022)$ \\
\hline Duration & & \\
\hline 6 months & 0.000 & (.) \\
\hline 1 year & $0.076^{* * *}$ & $(0.006)$ \\
\hline 2 years & $0.140^{* * *}$ & $(0.006)$ \\
\hline 5 years & $0.204^{* * *}$ & $(0.007)$ \\
\hline Efficacy & & \\
\hline $55 \%$ & 0.000 & (.) \\
\hline $65 \%$ & $0.080^{* * *}$ & $(0.006)$ \\
\hline $75 \%$ & $0.176^{* * *}$ & $(0.007)$ \\
\hline $85 \%$ & $0.255^{* * *}$ & $(0.007)$ \\
\hline $95 \%$ & $0.347^{* * *}$ & $(0.008)$ \\
\hline Doses & & \\
\hline 1 & 0.000 & (.) \\
\hline 2 & $-0.021^{* * *}$ & $(0.005)$ \\
\hline 3 & $-0.053^{* * *}$ & $(0.005)$ \\
\hline Technology & & \\
\hline RNA (None) & 0.000 & (.) \\
\hline Protein subunit (Hepatitis B) & $0.024^{* * *}$ & $(0.006)$ \\
\hline Viral vector (Ebola) & $0.025^{* * *}$ & $(0.006)$ \\
\hline Whole virus (Pertussis) & $0.040^{* * *}$ & $(0.006)$ \\
\hline Endorser & & \\
\hline Unspecified & 0.000 & (.) \\
\hline Government leaders & $0.022^{* *}$ & $(0.008)$ \\
\hline Opposition leaders & 0.012 & $(0.008)$ \\
\hline Leading entrepreneurs & $0.022^{* *}$ & $(0.008)$ \\
\hline Leading entertainers & 0.007 & $(0.007)$ \\
\hline Professional athletes & $0.018^{*}$ & $(0.008)$ \\
\hline Medical professionals & $0.087^{* * *}$ & $(0.008)$ \\
\hline Observations & 55629 & \\
\hline$R^{2}$ & 0.119 & \\
\hline
\end{tabular}

Standard errors in parentheses

* $p<0.05$, ** $p<0.01$, *** $p<0.001$ 
Table S17 Regression results for Brazil. This model is used to construct Figure 3.

\begin{tabular}{|c|c|c|}
\hline Developer & \multicolumn{2}{|c|}{$\begin{array}{c}(1) \\
\text { Vaccine Choice }(0 / 1)\end{array}$} \\
\hline Own & 0.000 & (.) \\
\hline Germany & $-0.051^{* *}$ & $(0.017)$ \\
\hline United States & $-0.050^{* *}$ & $(0.018)$ \\
\hline Russia & $-0.077^{* * *}$ & $(0.017)$ \\
\hline China & $-0.106^{* * *}$ & $(0.013)$ \\
\hline \multicolumn{3}{|l|}{ Producer } \\
\hline Own & 0.000 & (.) \\
\hline Germany & 0.007 & $(0.020)$ \\
\hline United States & 0.003 & $(0.020)$ \\
\hline Russia & -0.033 & $(0.020)$ \\
\hline China & -0.007 & $(0.013)$ \\
\hline \multicolumn{3}{|l|}{ Duration } \\
\hline 6 months & 0.000 & (.) \\
\hline 1 year & $0.101^{* * *}$ & $(0.008)$ \\
\hline 2 years & $0.160^{* * *}$ & $(0.009)$ \\
\hline 5 years & $0.223^{* * *}$ & $(0.009)$ \\
\hline \multicolumn{3}{|l|}{ Efficacy } \\
\hline $55 \%$ & 0.000 & (.) \\
\hline $65 \%$ & $0.080^{* * *}$ & $(0.009)$ \\
\hline $75 \%$ & $0.177^{* * *}$ & $(0.009)$ \\
\hline $85 \%$ & $0.265^{* * *}$ & $(0.009)$ \\
\hline $95 \%$ & $0.340^{* * *}$ & $(0.011)$ \\
\hline \multicolumn{3}{|l|}{ Doses } \\
\hline 1 & 0.000 & (.) \\
\hline 2 & $-0.019^{* *}$ & $(0.007)$ \\
\hline 3 & $-0.050^{* * *}$ & $(0.007)$ \\
\hline \multicolumn{3}{|l|}{ Technology } \\
\hline RNA (None) & 0.000 & (.) \\
\hline Protein subunit (Hepatitis B) & $0.044^{* * *}$ & $(0.008)$ \\
\hline Viral vector (Ebola) & $0.035^{* * *}$ & $(0.008)$ \\
\hline Whole virus (Pertussis) & $0.062^{* * *}$ & $(0.008)$ \\
\hline \multicolumn{3}{|l|}{ Endorser } \\
\hline Unspecified & 0.000 & (.) \\
\hline Government leaders & 0.015 & $(0.010)$ \\
\hline Opposition leaders & -0.010 & $(0.011)$ \\
\hline Leading entrepreneurs & 0.006 & $(0.010)$ \\
\hline Leading entertainers & 0.006 & $(0.010)$ \\
\hline Professional athletes & -0.011 & $(0.010)$ \\
\hline Medical professionals & $0.081^{* * *}$ & $(0.011)$ \\
\hline Observations & 30480 & \\
\hline$R^{2}$ & 0.100 & \\
\hline
\end{tabular}


Table S18 Regression results for China. This model is used to construct Figure 3.

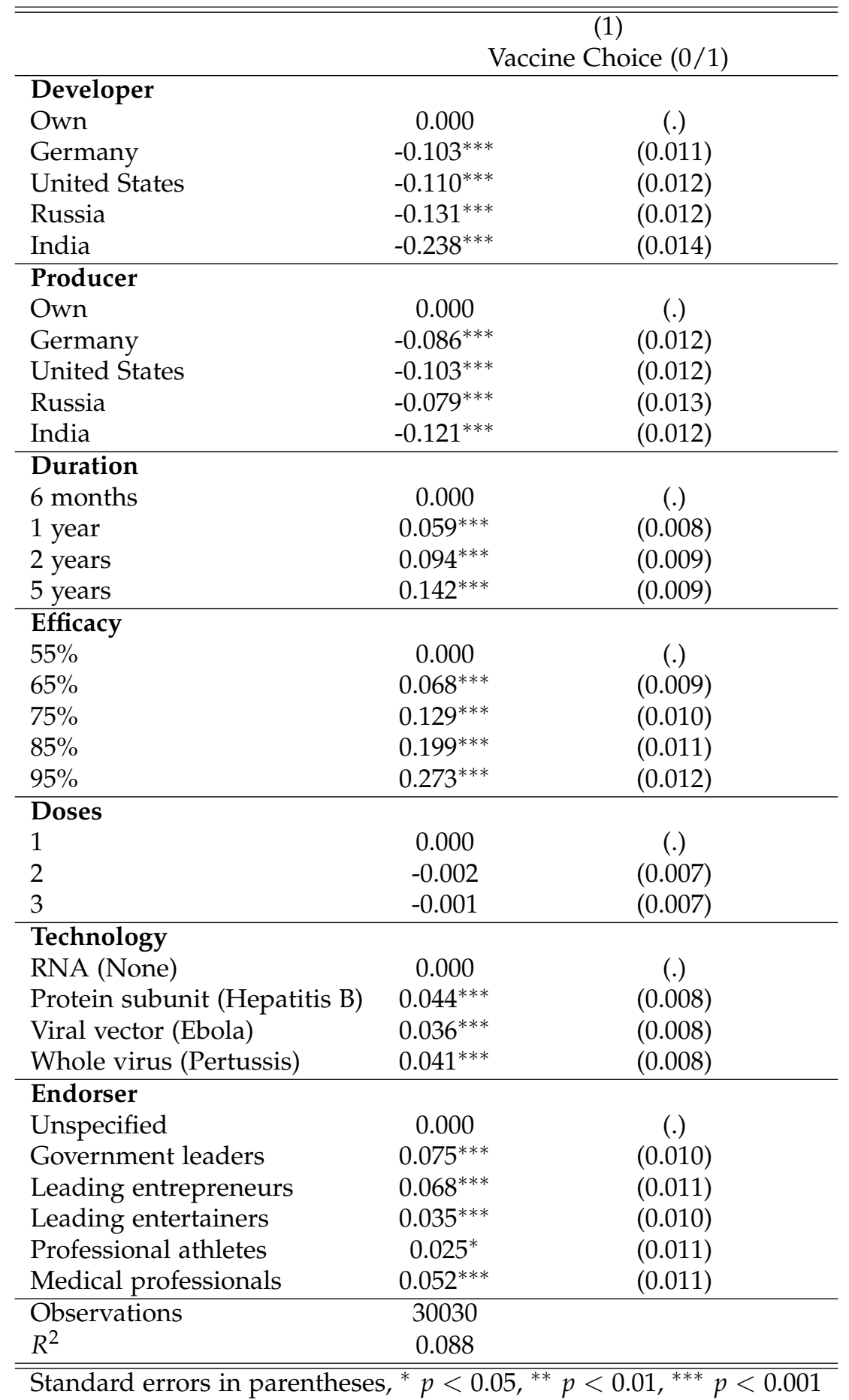


Table S19 Regression results for France. This model is used to construct Figure 3.

\begin{tabular}{|c|c|c|}
\hline Developer & \multicolumn{2}{|c|}{$\begin{array}{c}(1) \\
\text { Vaccine Choice }(0 / 1)\end{array}$} \\
\hline Own & 0.000 & (.) \\
\hline Germany & -0.029 & $(0.017)$ \\
\hline United States & $-0.080^{* * *}$ & $(0.017)$ \\
\hline Russia & $-0.145^{* * *}$ & $(0.018)$ \\
\hline China & $-0.178^{* * *}$ & $(0.014)$ \\
\hline \multicolumn{3}{|l|}{ Producer } \\
\hline Own & 0.000 & (.) \\
\hline Germany & -0.032 & $(0.020)$ \\
\hline United States & -0.008 & $(0.020)$ \\
\hline Russia & -0.027 & $(0.020)$ \\
\hline China & -0.023 & $(0.013)$ \\
\hline \multicolumn{3}{|l|}{ Duration } \\
\hline 6 months & 0.000 & (.) \\
\hline 1 year & $0.088^{* * *}$ & $(0.008)$ \\
\hline 2 years & $0.139^{* * *}$ & $(0.009)$ \\
\hline 5 years & $0.197^{* * *}$ & $(0.009)$ \\
\hline \multicolumn{3}{|l|}{ Efficacy } \\
\hline $55 \%$ & 0.000 & (.) \\
\hline $65 \%$ & $0.087^{* * *}$ & $(0.009)$ \\
\hline $75 \%$ & $0.179^{* * *}$ & $(0.009)$ \\
\hline $85 \%$ & $0.263^{* * *}$ & $(0.010)$ \\
\hline $95 \%$ & $0.347^{* * *}$ & $(0.010)$ \\
\hline \multicolumn{3}{|l|}{ Doses } \\
\hline 1 & 0.000 & (.) \\
\hline 2 & $-0.029^{* * *}$ & $(0.006)$ \\
\hline 3 & $-0.063^{* * *}$ & $(0.007)$ \\
\hline \multicolumn{3}{|l|}{ Technology } \\
\hline RNA (None) & 0.000 & (.) \\
\hline Protein subunit (Hepatitis B) & 0.016 & $(0.008)$ \\
\hline Viral vector (Ebola) & $0.019^{*}$ & $(0.009)$ \\
\hline Whole virus (Pertussis) & $0.060^{* * *}$ & $(0.009)$ \\
\hline \multicolumn{3}{|l|}{ Endorser } \\
\hline Unspecified & 0.000 & (.) \\
\hline Government leaders & $0.039^{* * *}$ & $(0.010)$ \\
\hline Opposition leaders & 0.015 & $(0.010)$ \\
\hline Leading entrepreneurs & $0.021^{*}$ & $(0.010)$ \\
\hline Leading entertainers & 0.011 & $(0.010)$ \\
\hline Professional athletes & 0.014 & $(0.010)$ \\
\hline Medical professionals & $0.072^{* * *}$ & $(0.010)$ \\
\hline Observations & 31440 & \\
\hline$R^{2}$ & 0.109 & \\
\hline
\end{tabular}


Table S20 Regression results for Germany. This model is used to construct Figure 3.

\begin{tabular}{|c|c|c|}
\hline Developer & \multicolumn{2}{|c|}{$\begin{array}{c}(1) \\
\text { Vaccine Choice }(0 / 1)\end{array}$} \\
\hline Own & 0.000 & (.) \\
\hline France & $-0.072^{* * *}$ & $(0.017)$ \\
\hline United States & $-0.077^{* * *}$ & $(0.017)$ \\
\hline Russia & $-0.140^{* * *}$ & $(0.018)$ \\
\hline China & $-0.173^{* * *}$ & $(0.014)$ \\
\hline \multicolumn{3}{|l|}{ Producer } \\
\hline Own & 0.000 & (.) \\
\hline France & 0.016 & $(0.020)$ \\
\hline United States & -0.008 & $(0.020)$ \\
\hline Russia & $-0.044^{*}$ & $(0.020)$ \\
\hline China & $-0.026^{*}$ & $(0.013)$ \\
\hline \multicolumn{3}{|l|}{ Duration } \\
\hline 6 months & 0.000 & (.) \\
\hline 1 year & $0.084^{* * *}$ & $(0.008)$ \\
\hline 2 years & $0.127^{* * *}$ & $(0.009)$ \\
\hline 5 years & $0.221^{* * *}$ & $(0.009)$ \\
\hline \multicolumn{3}{|l|}{ Efficacy } \\
\hline $55 \%$ & 0.000 & (.) \\
\hline $65 \%$ & $0.095^{* * *}$ & $(0.008)$ \\
\hline $75 \%$ & $0.182^{* * *}$ & $(0.009)$ \\
\hline $85 \%$ & $0.261^{* * *}$ & $(0.009)$ \\
\hline $95 \%$ & $0.343^{* * *}$ & $(0.010)$ \\
\hline \multicolumn{3}{|l|}{ Doses } \\
\hline 1 & 0.000 & (.) \\
\hline 2 & $-0.035^{* * *}$ & $(0.006)$ \\
\hline 3 & $-0.061^{* * *}$ & $(0.007)$ \\
\hline \multicolumn{3}{|l|}{ Technology } \\
\hline RNA (None) & 0.000 & (.) \\
\hline Protein subunit (Hepatitis B) & $0.024^{* *}$ & $(0.008)$ \\
\hline Viral vector (Ebola) & 0.011 & $(0.008)$ \\
\hline Whole virus (Pertussis) & $0.026^{* *}$ & $(0.009)$ \\
\hline \multicolumn{3}{|l|}{ Endorser } \\
\hline Unspecified & 0.000 & (.) \\
\hline Government leaders & $0.031^{* *}$ & $(0.011)$ \\
\hline Opposition leaders & $0.033^{* * *}$ & $(0.010)$ \\
\hline Leading entrepreneurs & $0.034^{* * *}$ & $(0.010)$ \\
\hline Leading entertainers & $0.026^{*}$ & $(0.010)$ \\
\hline Professional athletes & $0.022^{*}$ & $(0.010)$ \\
\hline Medical professionals & $0.062^{* * *}$ & $(0.010)$ \\
\hline Observations & 30930 & \\
\hline$R^{2}$ & 0.108 & \\
\hline
\end{tabular}


Table S21 Regression results for Hong Kong. This model is used to construct Figure 3.

\begin{tabular}{|c|c|c|}
\hline Developer & \multicolumn{2}{|c|}{$\begin{array}{c}(1) \\
\text { Vaccine Choice }(0 / 1)\end{array}$} \\
\hline Own & 0.000 & (.) \\
\hline Germany & $0.053^{* * *}$ & $(0.013)$ \\
\hline United States & 0.022 & $(0.013)$ \\
\hline Russia & $-0.083^{* * *}$ & $(0.013)$ \\
\hline China & $-0.076^{* * *}$ & $(0.013)$ \\
\hline \multicolumn{3}{|l|}{ Producer } \\
\hline Own & 0.000 & (.) \\
\hline Germany & -0.017 & $(0.017)$ \\
\hline United States & -0.017 & $(0.017)$ \\
\hline Russia & $-0.061^{* * *}$ & $(0.017)$ \\
\hline China & $-0.099^{* * *}$ & $(0.013)$ \\
\hline \multicolumn{3}{|l|}{ Duration } \\
\hline 6 months & 0.000 & (.) \\
\hline 1 year & $0.067^{* * *}$ & $(0.008)$ \\
\hline 2 years & $0.130^{* * *}$ & $(0.009)$ \\
\hline 5 years & $0.186^{* * *}$ & $(0.009)$ \\
\hline \multicolumn{3}{|l|}{ Efficacy } \\
\hline $55 \%$ & 0.000 & (.) \\
\hline $65 \%$ & $0.079^{* * *}$ & $(0.009)$ \\
\hline $75 \%$ & $0.185^{* * *}$ & $(0.009)$ \\
\hline $85 \%$ & $0.266^{* * *}$ & $(0.010)$ \\
\hline $95 \%$ & $0.357^{* * *}$ & $(0.011)$ \\
\hline \multicolumn{3}{|l|}{ Doses } \\
\hline 1 & 0.000 & (.) \\
\hline 2 & $-0.029^{* * *}$ & $(0.007)$ \\
\hline 3 & $-0.056^{* * *}$ & $(0.007)$ \\
\hline \multicolumn{3}{|l|}{ Technology } \\
\hline RNA (None) & 0.000 & (.) \\
\hline Protein subunit (Hepatitis B) & $0.075^{* * *}$ & $(0.008)$ \\
\hline Viral vector (Ebola) & $0.062^{* * *}$ & $(0.008)$ \\
\hline Whole virus (Pertussis) & $0.042^{* * *}$ & $(0.008)$ \\
\hline \multicolumn{3}{|l|}{ Endorser } \\
\hline Unspecified & 0.000 & (.) \\
\hline Government leaders & $0.028^{* *}$ & $(0.011)$ \\
\hline Opposition leaders & $0.021^{*}$ & $(0.011)$ \\
\hline Leading entrepreneurs & $0.048^{* * *}$ & $(0.011)$ \\
\hline Leading entertainers & $0.025^{*}$ & $(0.010)$ \\
\hline Professional athletes & $0.032^{* *}$ & $(0.010)$ \\
\hline Medical professionals & $0.102^{* * *}$ & $(0.011)$ \\
\hline Observations & 30000 & \\
\hline$R^{2}$ & 0.116 & \\
\hline
\end{tabular}


Table S22 Regression results for Japan. This model is used to construct Figure 3.

\begin{tabular}{|c|c|c|}
\hline Developer & \multicolumn{2}{|c|}{$\begin{array}{c}(1) \\
\text { Vaccine Choice }(0 / 1)\end{array}$} \\
\hline Own & 0.000 & (.) \\
\hline Germany & $-0.141^{* * *}$ & $(0.012)$ \\
\hline United States & $-0.134^{* * *}$ & $(0.013)$ \\
\hline Russia & $-0.281^{* * *}$ & $(0.012)$ \\
\hline China & $-0.342^{* * *}$ & $(0.013)$ \\
\hline \multicolumn{3}{|l|}{ Producer } \\
\hline Own & 0.000 & (.) \\
\hline Germany & $-0.035^{*}$ & $(0.016)$ \\
\hline United States & -0.020 & $(0.016)$ \\
\hline Russia & $-0.104^{* * *}$ & $(0.015)$ \\
\hline China & $-0.190^{* * *}$ & $(0.011)$ \\
\hline \multicolumn{3}{|l|}{ Duration } \\
\hline 6 months & 0.000 & (.) \\
\hline 1 year & $0.050^{* * *}$ & $(0.008)$ \\
\hline 2 years & $0.083^{* * *}$ & $(0.008)$ \\
\hline 5 years & $0.128^{* * *}$ & $(0.008)$ \\
\hline \multicolumn{3}{|l|}{ Efficacy } \\
\hline $55 \%$ & 0.000 & (.) \\
\hline $65 \%$ & $0.065^{* * *}$ & $(0.008)$ \\
\hline $75 \%$ & $0.114^{* * *}$ & $(0.009)$ \\
\hline $85 \%$ & $0.196^{* * *}$ & $(0.010)$ \\
\hline $95 \%$ & $0.246^{* * *}$ & $(0.011)$ \\
\hline \multicolumn{3}{|l|}{ Doses } \\
\hline 1 & 0.000 & (.) \\
\hline 2 & $-0.014^{*}$ & $(0.007)$ \\
\hline 3 & $-0.032^{* * *}$ & $(0.007)$ \\
\hline \multicolumn{3}{|l|}{ Technology } \\
\hline RNA (None) & 0.000 & (.) \\
\hline Protein subunit (Hepatitis B) & $0.049^{* * *}$ & $(0.009)$ \\
\hline Viral vector (Ebola) & $0.065^{* * *}$ & $(0.008)$ \\
\hline Whole virus (Pertussis) & $0.063^{* * *}$ & $(0.008)$ \\
\hline \multicolumn{3}{|l|}{ Endorser } \\
\hline Unspecified & 0.000 & (.) \\
\hline Government leaders & $0.033^{* *}$ & $(0.010)$ \\
\hline Opposition leaders & $0.028^{* *}$ & $(0.010)$ \\
\hline Leading entrepreneurs & 0.019 & $(0.010)$ \\
\hline Leading entertainers & 0.014 & $(0.010)$ \\
\hline Professional athletes & $0.031^{* *}$ & $(0.010)$ \\
\hline Medical professionals & $0.073^{* * *}$ & $(0.010)$ \\
\hline Observations & 30000 & \\
\hline$R^{2}$ & 0.149 & \\
\hline
\end{tabular}


Table S23 Regression results for Mexico. This model is used to construct Figure 3.

\begin{tabular}{|c|c|c|}
\hline \multirow{2}{*}{ Developer } & \multicolumn{2}{|c|}{$\begin{array}{c}(1) \\
\text { Vaccine Choice }(0 / 1)\end{array}$} \\
\hline & & \\
\hline Own & 0.000 & (.) \\
\hline Germany & 0.003 & $(0.017)$ \\
\hline United States & 0.003 & $(0.018)$ \\
\hline Russia & 0.028 & $(0.017)$ \\
\hline China & $-0.034^{*}$ & $(0.013)$ \\
\hline \multicolumn{3}{|l|}{ Producer } \\
\hline Own & 0.000 & (.) \\
\hline Germany & -0.002 & $(0.020)$ \\
\hline United States & -0.018 & $(0.020)$ \\
\hline Russia & -0.035 & $(0.020)$ \\
\hline China & -0.021 & $(0.013)$ \\
\hline \multicolumn{3}{|l|}{ Duration } \\
\hline 6 months & 0.000 & (.) \\
\hline 1 year & $0.063^{* * *}$ & $(0.008)$ \\
\hline 2 years & $0.135^{* * *}$ & $(0.008)$ \\
\hline 5 years & $0.192^{* * *}$ & $(0.009)$ \\
\hline \multicolumn{3}{|l|}{ Efficacy } \\
\hline $55 \%$ & 0.000 & (.) \\
\hline $65 \%$ & $0.086^{* * *}$ & $(0.009)$ \\
\hline $75 \%$ & $0.185^{* * *}$ & $(0.009)$ \\
\hline $85 \%$ & $0.264^{* * *}$ & $(0.010)$ \\
\hline $95 \%$ & $0.348^{* * *}$ & $(0.010)$ \\
\hline \multicolumn{3}{|l|}{ Doses } \\
\hline 1 & 0.000 & (.) \\
\hline 2 & $-0.021^{* *}$ & $(0.007)$ \\
\hline 3 & $-0.047^{* * *}$ & $(0.007)$ \\
\hline \multicolumn{3}{|l|}{ Technology } \\
\hline RNA (None) & 0.000 & (.) \\
\hline Protein subunit (Hepatitis B) & $0.039^{* * *}$ & $(0.008)$ \\
\hline Viral vector (Ebola) & $0.057^{* * *}$ & $(0.010)$ \\
\hline Whole virus (Pertussis) & $0.074^{* * *}$ & $(0.008)$ \\
\hline \multicolumn{3}{|l|}{ Endorser } \\
\hline Unspecified & 0.000 & (.) \\
\hline Government leaders & $0.028^{* *}$ & $(0.010)$ \\
\hline Opposition leaders & 0.013 & $(0.011)$ \\
\hline Leading entrepreneurs & $0.031^{* *}$ & $(0.010)$ \\
\hline Leading entertainers & 0.004 & $(0.010)$ \\
\hline Professional athletes & 0.019 & $(0.011)$ \\
\hline Medical professionals & $0.092^{* * *}$ & $(0.010)$ \\
\hline Observations & 30957 & \\
\hline$R^{2}$ & 0.092 & \\
\hline
\end{tabular}


Table S24 Regression results for Philippines. This model is used to construct Figure 3.

\begin{tabular}{|c|c|c|}
\hline Developer & \multicolumn{2}{|c|}{$\begin{array}{c}(1) \\
\text { Vaccine Choice }(0 / 1)\end{array}$} \\
\hline Own & 0.000 & (.) \\
\hline Germany & 0.006 & $(0.012)$ \\
\hline United States & $0.039^{* *}$ & $(0.012)$ \\
\hline Russia & -0.007 & $(0.012)$ \\
\hline China & $-0.065^{* * *}$ & $(0.012)$ \\
\hline \multicolumn{3}{|l|}{ Producer } \\
\hline Own & 0.000 & (.) \\
\hline Germany & -0.005 & $(0.017)$ \\
\hline United States & -0.003 & $(0.016)$ \\
\hline Russia & -0.027 & $(0.016)$ \\
\hline China & $-0.068^{* * *}$ & $(0.012)$ \\
\hline \multicolumn{3}{|l|}{ Duration } \\
\hline 6 months & 0.000 & (.) \\
\hline 1 year & $0.086^{* * *}$ & $(0.008)$ \\
\hline 2 years & $0.142^{* * *}$ & $(0.009)$ \\
\hline 5 years & $0.222^{* * *}$ & $(0.009)$ \\
\hline \multicolumn{3}{|l|}{ Efficacy } \\
\hline $55 \%$ & 0.000 & (.) \\
\hline $65 \%$ & $0.072^{* * *}$ & $(0.009)$ \\
\hline $75 \%$ & $0.175^{* * *}$ & $(0.009)$ \\
\hline $85 \%$ & $0.266^{* * *}$ & $(0.010)$ \\
\hline $95 \%$ & $0.363^{* * *}$ & $(0.011)$ \\
\hline \multicolumn{3}{|l|}{ Doses } \\
\hline 1 & 0.000 & (.) \\
\hline 2 & $-0.020^{* *}$ & $(0.007)$ \\
\hline 3 & $-0.033^{* * *}$ & $(0.007)$ \\
\hline \multicolumn{3}{|l|}{ Technology } \\
\hline RNA (None) & 0.000 & (.) \\
\hline Protein subunit (Hepatitis B) & $0.063^{* * *}$ & $(0.008)$ \\
\hline Viral vector (Ebola) & $0.065^{* * *}$ & $(0.008)$ \\
\hline Whole virus (Pertussis) & $0.086^{* * *}$ & $(0.008)$ \\
\hline \multicolumn{3}{|l|}{ Endorser } \\
\hline Unspecified & 0.000 & (.) \\
\hline Government leaders & $0.064^{* * *}$ & $(0.011)$ \\
\hline Opposition leaders & 0.006 & $(0.011)$ \\
\hline Leading entrepreneurs & $0.055^{* * *}$ & $(0.010)$ \\
\hline Leading entertainers & $0.025^{*}$ & $(0.010)$ \\
\hline Professional athletes & $0.071^{* * *}$ & $(0.011)$ \\
\hline Medical professionals & $0.148^{* * *}$ & $(0.011)$ \\
\hline Observations & 30000 & \\
\hline$R^{2}$ & 0.118 & \\
\hline
\end{tabular}


Table S25 Regression results for South Korea. This model is used to construct Figure 3.

\begin{tabular}{|c|c|c|}
\hline \multirow{2}{*}{ Developer } & \multicolumn{2}{|c|}{$\begin{array}{c}(1) \\
\text { Vaccine Choice }(0 / 1)\end{array}$} \\
\hline & & \\
\hline Own & 0.000 & (.) \\
\hline Germany & $-0.051^{* * *}$ & $(0.013)$ \\
\hline United States & $-0.033^{* *}$ & $(0.012)$ \\
\hline Russia & $-0.175^{* * *}$ & $(0.013)$ \\
\hline China & $-0.273^{* * *}$ & $(0.012)$ \\
\hline \multicolumn{3}{|l|}{ Producer } \\
\hline Own & 0.000 & (.) \\
\hline Germany & -0.004 & $(0.017)$ \\
\hline United States & -0.008 & $(0.016)$ \\
\hline Russia & $-0.059^{* * *}$ & $(0.017)$ \\
\hline China & $-0.149^{* * *}$ & $(0.012)$ \\
\hline \multicolumn{3}{|l|}{ Duration } \\
\hline 6 months & 0.000 & (.) \\
\hline 1 year & $0.071^{* * *}$ & $(0.008)$ \\
\hline 2 years & $0.125^{* * *}$ & $(0.008)$ \\
\hline 5 years & $0.179^{* * *}$ & $(0.009)$ \\
\hline \multicolumn{3}{|l|}{ Efficacy } \\
\hline $55 \%$ & 0.000 & (.) \\
\hline $65 \%$ & $0.101^{* * *}$ & $(0.009)$ \\
\hline $75 \%$ & $0.188^{* * *}$ & $(0.009)$ \\
\hline $85 \%$ & $0.283^{* * *}$ & $(0.010)$ \\
\hline $95 \%$ & $0.372^{* * *}$ & $(0.010)$ \\
\hline \multicolumn{3}{|l|}{ Doses } \\
\hline 1 & 0.000 & (.) \\
\hline 2 & $-0.031^{* * *}$ & $(0.006)$ \\
\hline 3 & $-0.054^{* * *}$ & $(0.007)$ \\
\hline \multicolumn{3}{|l|}{ Technology } \\
\hline RNA (None) & 0.000 & (.) \\
\hline Protein subunit (Hepatitis B) & $0.035^{* * *}$ & $(0.008)$ \\
\hline Viral vector (Ebola) & $0.041^{* * *}$ & $(0.008)$ \\
\hline Whole virus (Pertussis) & $0.045^{* * *}$ & $(0.008)$ \\
\hline \multicolumn{3}{|l|}{ Endorser } \\
\hline Unspecified & 0.000 & (.) \\
\hline Government leaders & $0.047^{* * *}$ & $(0.010)$ \\
\hline Opposition leaders & $0.022^{*}$ & $(0.010)$ \\
\hline Leading entrepreneurs & $0.034^{* * *}$ & $(0.010)$ \\
\hline Leading entertainers & $0.025^{*}$ & $(0.010)$ \\
\hline Professional athletes & $0.024^{*}$ & $(0.010)$ \\
\hline Medical professionals & $0.081^{* * *}$ & $(0.010)$ \\
\hline Observations & 30000 & \\
\hline$R^{2}$ & 0.159 & \\
\hline
\end{tabular}


Table S26 Regression results for Singapore. This model is used to construct Figure 3.

\begin{tabular}{|c|c|c|}
\hline Developer & \multicolumn{2}{|c|}{$\begin{array}{c}(1) \\
\text { Vaccine Choice }(0 / 1)\end{array}$} \\
\hline Own & 0.000 & (.) \\
\hline Germany & $-0.075^{* * *}$ & $(0.012)$ \\
\hline United States & $-0.077^{* * *}$ & $(0.012)$ \\
\hline Russia & $-0.167^{* * *}$ & $(0.012)$ \\
\hline China & $-0.127^{* * *}$ & $(0.012)$ \\
\hline \multicolumn{3}{|l|}{ Producer } \\
\hline Own & 0.000 & (.) \\
\hline Germany & -0.023 & $(0.016)$ \\
\hline United States & -0.026 & $(0.016)$ \\
\hline Russia & $-0.071^{* * *}$ & $(0.016)$ \\
\hline China & $-0.075^{* * *}$ & $(0.012)$ \\
\hline \multicolumn{3}{|l|}{ Duration } \\
\hline 6 months & 0.000 & (.) \\
\hline 1 year & $0.070^{* * *}$ & $(0.008)$ \\
\hline 2 years & $0.134^{* * *}$ & $(0.009)$ \\
\hline 5 years & $0.186^{* * *}$ & $(0.009)$ \\
\hline \multicolumn{3}{|l|}{ Efficacy } \\
\hline $55 \%$ & 0.000 & (.) \\
\hline $65 \%$ & $0.115^{* * *}$ & $(0.009)$ \\
\hline $75 \%$ & $0.219^{* * *}$ & $(0.009)$ \\
\hline $85 \%$ & $0.296^{* * *}$ & $(0.010)$ \\
\hline $95 \%$ & $0.401^{* * *}$ & $(0.011)$ \\
\hline \multicolumn{3}{|l|}{ Doses } \\
\hline 1 & 0.000 & (.) \\
\hline 2 & $-0.023^{* * *}$ & $(0.007)$ \\
\hline 3 & $-0.055^{* * *}$ & $(0.007)$ \\
\hline \multicolumn{3}{|l|}{ Technology } \\
\hline RNA (None) & 0.000 & (.) \\
\hline Protein subunit (Hepatitis B) & $0.038^{* * *}$ & $(0.008)$ \\
\hline Viral vector (Ebola) & $0.037^{* * *}$ & $(0.008)$ \\
\hline Whole virus (Pertussis) & $0.038^{* * *}$ & $(0.008)$ \\
\hline \multicolumn{3}{|l|}{ Endorser } \\
\hline Unspecified & 0.000 & (.) \\
\hline Government leaders & $0.079^{* * *}$ & $(0.011)$ \\
\hline Opposition leaders & 0.005 & $(0.010)$ \\
\hline Leading entrepreneurs & 0.015 & $(0.010)$ \\
\hline Leading entertainers & 0.003 & $(0.010)$ \\
\hline Professional athletes & $0.030^{* *}$ & $(0.011)$ \\
\hline Medical professionals & $0.100^{* * *}$ & $(0.011)$ \\
\hline Observations & 30000 & \\
\hline$R^{2}$ & 0.128 & \\
\hline
\end{tabular}


Table S27 Regression results for Spain. This model is used to construct Figure 3.

\begin{tabular}{|c|c|c|}
\hline \multirow{2}{*}{ Developer } & \multicolumn{2}{|c|}{$\begin{array}{c}(1) \\
\text { Choice (Binary) }\end{array}$} \\
\hline & & \\
\hline Own & 0.000 & (.) \\
\hline Germany & -0.024 & $(0.013)$ \\
\hline United States & $-0.027^{*}$ & $(0.013)$ \\
\hline Russia & $-0.075^{* * *}$ & $(0.013)$ \\
\hline China & $-0.085^{* * *}$ & $(0.010)$ \\
\hline \multicolumn{3}{|l|}{ Producer } \\
\hline Own & 0.000 & (.) \\
\hline Germany & -0.009 & $(0.015)$ \\
\hline United States & $-0.050^{* * *}$ & $(0.015)$ \\
\hline Russia & $-0.038^{* *}$ & $(0.015)$ \\
\hline China & $-0.036^{* * *}$ & $(0.009)$ \\
\hline \multicolumn{3}{|l|}{ Duration } \\
\hline 6 months & 0.000 & (.) \\
\hline 1 year & $0.078^{* * *}$ & $(0.006)$ \\
\hline 2 years & $0.148^{* * *}$ & $(0.006)$ \\
\hline 5 years & $0.227^{* * *}$ & $(0.007)$ \\
\hline \multicolumn{3}{|l|}{ Efficacy } \\
\hline $55 \%$ & 0.000 & (.) \\
\hline $65 \%$ & $0.101^{* * *}$ & $(0.006)$ \\
\hline $75 \%$ & $0.207^{* * *}$ & $(0.007)$ \\
\hline $85 \%$ & $0.302^{* * *}$ & $(0.007)$ \\
\hline $95 \%$ & $0.393^{* * *}$ & $(0.008)$ \\
\hline \multicolumn{3}{|l|}{ Doses } \\
\hline 1 & 0.000 & (.) \\
\hline 2 & $-0.027^{* * *}$ & $(0.005)$ \\
\hline 3 & $-0.051^{* * *}$ & $(0.005)$ \\
\hline \multicolumn{3}{|l|}{ Technology } \\
\hline RNA (None) & 0.000 & (.) \\
\hline Protein subunit (Hepatitis B) & $0.042^{* * *}$ & $(0.006)$ \\
\hline Viral vector (Ebola) & $0.051^{* * *}$ & $(0.008)$ \\
\hline Whole virus (Pertussis) & $0.056^{* * *}$ & $(0.006)$ \\
\hline \multicolumn{3}{|l|}{ Endorser } \\
\hline Unspecified & 0.000 & (.) \\
\hline Government leaders & -0.007 & $(0.008)$ \\
\hline Opposition leaders & -0.009 & $(0.008)$ \\
\hline Leading entrepreneurs & 0.013 & $(0.007)$ \\
\hline Leading entertainers & $-0.026^{* * *}$ & $(0.008)$ \\
\hline Professional athletes & -0.005 & $(0.008)$ \\
\hline Medical professionals & $0.092^{* * *}$ & $(0.008)$ \\
\hline Observations & 52516 & \\
\hline$R^{2}$ & 0.123 & \\
\hline
\end{tabular}


Table S28 Regression results for Taiwan. This model is used to construct Figure 3.

\begin{tabular}{|c|c|c|}
\hline Developer & \multicolumn{2}{|c|}{$\begin{array}{c}(1) \\
\text { Vaccine Choice }(0 / 1)\end{array}$} \\
\hline Own & 0.000 & (.) \\
\hline Germany & $-0.051^{* * *}$ & $(0.012)$ \\
\hline United States & $-0.046^{* * *}$ & $(0.011)$ \\
\hline Russia & $-0.144^{* * *}$ & $(0.012)$ \\
\hline China & $-0.213^{* * *}$ & $(0.012)$ \\
\hline \multicolumn{3}{|l|}{ Producer } \\
\hline Own & 0.000 & (.) \\
\hline Germany & 0.014 & $(0.015)$ \\
\hline United States & -0.020 & $(0.015)$ \\
\hline Russia & $-0.053^{* * *}$ & $(0.015)$ \\
\hline China & $-0.213^{* * *}$ & $(0.011)$ \\
\hline \multicolumn{3}{|l|}{ Duration } \\
\hline 6 months & 0.000 & (.) \\
\hline 1 year & $0.041^{* * *}$ & $(0.007)$ \\
\hline 2 years & $0.083^{* * *}$ & $(0.007)$ \\
\hline 5 years & $0.122^{* * *}$ & $(0.008)$ \\
\hline \multicolumn{3}{|l|}{ Efficacy } \\
\hline $55 \%$ & 0.000 & (.) \\
\hline $65 \%$ & $0.078^{* * *}$ & $(0.008)$ \\
\hline $75 \%$ & $0.162^{* * *}$ & $(0.009)$ \\
\hline $85 \%$ & $0.245^{* * *}$ & $(0.009)$ \\
\hline $95 \%$ & $0.316^{* * *}$ & $(0.010)$ \\
\hline \multicolumn{3}{|l|}{ Doses } \\
\hline 1 & 0.000 & (.) \\
\hline 2 & $-0.026^{* * *}$ & $(0.006)$ \\
\hline 3 & $-0.035^{* * *}$ & $(0.006)$ \\
\hline \multicolumn{3}{|l|}{ Technology } \\
\hline RNA (None) & 0.000 & (.) \\
\hline Protein subunit (Hepatitis B) & $0.064^{* * *}$ & $(0.008)$ \\
\hline Viral vector (Ebola) & $0.075^{* * *}$ & $(0.008)$ \\
\hline Whole virus (Pertussis) & $0.046^{* * *}$ & $(0.008)$ \\
\hline \multicolumn{3}{|l|}{ Endorser } \\
\hline Unspecified & 0.000 & (.) \\
\hline Government leaders & $0.046^{* * *}$ & $(0.009)$ \\
\hline Opposition leaders & $0.036^{* * *}$ & $(0.010)$ \\
\hline Leading entrepreneurs & $0.055^{* * *}$ & $(0.009)$ \\
\hline Leading entertainers & $0.020^{*}$ & $(0.009)$ \\
\hline Professional athletes & $0.028^{* *}$ & $(0.009)$ \\
\hline Medical professionals & $0.099^{* * *}$ & $(0.010)$ \\
\hline Observations & 36060 & \\
\hline$R^{2}$ & 0.142 & \\
\hline
\end{tabular}


Table S29 Regression results for United Kingdom. This model is used to construct Figure 3.

\begin{tabular}{|c|c|c|}
\hline Developer & \multicolumn{2}{|c|}{$\begin{array}{c}(1) \\
\text { Vaccine Choice }(0 / 1)\end{array}$} \\
\hline Own & 0.000 & (.) \\
\hline Germany & $-0.034^{*}$ & $(0.017)$ \\
\hline United States & $-0.063^{* * *}$ & $(0.017)$ \\
\hline Russia & $-0.163^{* * *}$ & $(0.018)$ \\
\hline China & $-0.161^{* * *}$ & $(0.014)$ \\
\hline \multicolumn{3}{|l|}{ Producer } \\
\hline Own & 0.000 & (.) \\
\hline Germany & $-0.044^{*}$ & $(0.019)$ \\
\hline United States & -0.035 & $(0.020)$ \\
\hline Russia & -0.018 & $(0.020)$ \\
\hline China & $-0.034^{* *}$ & $(0.013)$ \\
\hline \multicolumn{3}{|l|}{ Duration } \\
\hline 6 months & 0.000 & (.) \\
\hline 1 year & $0.084^{* * *}$ & $(0.008)$ \\
\hline 2 years & $0.146^{* * *}$ & $(0.008)$ \\
\hline 5 years & $0.217^{* * *}$ & $(0.009)$ \\
\hline \multicolumn{3}{|l|}{ Efficacy } \\
\hline $55 \%$ & 0.000 & (.) \\
\hline $65 \%$ & $0.081^{* * *}$ & $(0.009)$ \\
\hline $75 \%$ & $0.193^{* * *}$ & $(0.009)$ \\
\hline $85 \%$ & $0.283^{* * *}$ & $(0.010)$ \\
\hline $95 \%$ & $0.373^{* * *}$ & $(0.010)$ \\
\hline \multicolumn{3}{|l|}{ Doses } \\
\hline 1 & 0.000 & (.) \\
\hline 2 & $-0.029^{* * *}$ & $(0.007)$ \\
\hline 3 & $-0.065^{* * *}$ & $(0.007)$ \\
\hline \multicolumn{3}{|l|}{ Technology } \\
\hline RNA (None) & 0.000 & (.) \\
\hline Protein subunit (Hepatitis B) & $0.043^{* * *}$ & $(0.008)$ \\
\hline Viral vector (Ebola) & $0.037^{* * *}$ & $(0.008)$ \\
\hline Whole virus (Pertussis) & $0.066^{* * *}$ & $(0.008)$ \\
\hline \multicolumn{3}{|l|}{ Endorser } \\
\hline Unspecified & 0.000 & (.) \\
\hline Government leaders & $0.028^{* *}$ & $(0.010)$ \\
\hline Opposition leaders & 0.014 & $(0.010)$ \\
\hline Leading entrepreneurs & 0.014 & $(0.010)$ \\
\hline Leading entertainers & 0.004 & $(0.010)$ \\
\hline Professional athletes & 0.004 & $(0.010)$ \\
\hline Medical professionals & $0.084^{* * *}$ & $(0.010)$ \\
\hline Observations & 31230 & \\
\hline$R^{2}$ & 0.127 & \\
\hline
\end{tabular}


Table S30 Regression results for United States. This model is used to construct Figure 3.

\begin{tabular}{|c|c|c|}
\hline Developer & \multicolumn{2}{|c|}{$\begin{array}{c}(1) \\
\text { Vaccine Choice }(0 / 1)\end{array}$} \\
\hline Own & 0.000 & (.) \\
\hline Germany & $-0.083^{* * *}$ & $(0.017)$ \\
\hline United Kingdom & $-0.074^{* * *}$ & $(0.017)$ \\
\hline Russia & $-0.136^{* * *}$ & $(0.018)$ \\
\hline China & $-0.196^{* * *}$ & $(0.014)$ \\
\hline \multicolumn{3}{|l|}{ Producer } \\
\hline Own & 0.000 & (.) \\
\hline Germany & -0.010 & $(0.019)$ \\
\hline United Kingdom & -0.019 & $(0.019)$ \\
\hline Russia & $-0.072^{* * *}$ & $(0.020)$ \\
\hline China & $-0.036^{* *}$ & $(0.012)$ \\
\hline \multicolumn{3}{|l|}{ Duration } \\
\hline 6 months & 0.000 & (.) \\
\hline 1 year & $0.044^{* * *}$ & $(0.008)$ \\
\hline 2 years & $0.073^{* * *}$ & $(0.008)$ \\
\hline 5 years & $0.134^{* * *}$ & $(0.008)$ \\
\hline \multicolumn{3}{|l|}{ Efficacy } \\
\hline $55 \%$ & 0.000 & (.) \\
\hline $65 \%$ & $0.067^{* * *}$ & $(0.008)$ \\
\hline $75 \%$ & $0.123^{* * *}$ & $(0.009)$ \\
\hline $85 \%$ & $0.192^{* * *}$ & $(0.010)$ \\
\hline $95 \%$ & $0.249^{* * *}$ & $(0.011)$ \\
\hline \multicolumn{3}{|l|}{ Doses } \\
\hline 1 & 0.000 & (.) \\
\hline 2 & $-0.021^{* *}$ & $(0.006)$ \\
\hline 3 & $-0.034^{* * *}$ & $(0.007)$ \\
\hline \multicolumn{3}{|l|}{ Technology } \\
\hline RNA (None) & 0.000 & (.) \\
\hline Protein subunit (Hepatitis B) & $0.018^{*}$ & $(0.008)$ \\
\hline Viral vector (Ebola) & $0.021^{* *}$ & $(0.008)$ \\
\hline Whole virus (Pertussis) & $0.034^{* * *}$ & $(0.008)$ \\
\hline \multicolumn{3}{|l|}{ Endorser } \\
\hline Unspecified & 0.000 & (.) \\
\hline Government leaders & $0.035^{* * *}$ & $(0.010)$ \\
\hline Opposition leaders & 0.003 & $(0.010)$ \\
\hline Leading entrepreneurs & $0.022^{*}$ & $(0.010)$ \\
\hline Leading entertainers & -0.003 & $(0.010)$ \\
\hline Professional athletes & 0.013 & $(0.010)$ \\
\hline Medical professionals & $0.057^{* * *}$ & $(0.010)$ \\
\hline Observations & 34050 & \\
\hline$R^{2}$ & 0.070 & \\
\hline
\end{tabular}


Table S31 Regression results by Nationalism (25th/75th percentile split) for Brazil.

\begin{tabular}{|c|c|c|c|c|}
\hline \multirow{2}{*}{ Developer } & \multicolumn{2}{|c|}{ Low Nationalism } & \multicolumn{2}{|c|}{ High Nationalism } \\
\hline & \multicolumn{2}{|c|}{ Vaccine Choice $(0 / 1)$} & \multicolumn{2}{|c|}{ Vaccine Choice $(0 / 1)$} \\
\hline & & & & \\
\hline Own & 0.000 & (.) & 0.000 & (.) \\
\hline Germany & -0.050 & $(0.027)$ & $-0.093^{* *}$ & $(0.033)$ \\
\hline United States & -0.054 & $(0.029)$ & -0.044 & $(0.035)$ \\
\hline Russia & $-0.064^{*}$ & $(0.027)$ & $-0.137^{* * *}$ & $(0.035)$ \\
\hline China & $-0.096^{* * *}$ & $(0.022)$ & $-0.161^{* * *}$ & $(0.027)$ \\
\hline \multicolumn{5}{|l|}{ Producer } \\
\hline Own & 0.000 & (.) & 0.000 & (.) \\
\hline Germany & 0.026 & $(0.032)$ & 0.002 & $(0.040)$ \\
\hline United States & 0.023 & $(0.033)$ & -0.040 & $(0.039)$ \\
\hline Russia & -0.018 & $(0.032)$ & -0.043 & $(0.039)$ \\
\hline China & 0.011 & $(0.022)$ & -0.023 & $(0.025)$ \\
\hline \multicolumn{5}{|l|}{ Duration } \\
\hline 6 months & 0.000 & (.) & 0.000 & (.) \\
\hline 1 year & $0.117^{* * *}$ & $(0.013)$ & $0.083^{* * *}$ & $(0.015)$ \\
\hline 2 years & $0.203^{* * *}$ & $(0.013)$ & $0.125^{* * *}$ & $(0.017)$ \\
\hline 5 years & $0.259^{* * *}$ & $(0.015)$ & $0.199^{* * *}$ & $(0.018)$ \\
\hline \multicolumn{5}{|l|}{ Efficacy } \\
\hline $55 \%$ & 0.000 & (.) & 0.000 & (.) \\
\hline $65 \%$ & $0.093^{* * *}$ & $(0.015)$ & $0.061^{* * *}$ & $(0.017)$ \\
\hline $75 \%$ & $0.175^{* * *}$ & $(0.014)$ & $0.183^{* * *}$ & $(0.017)$ \\
\hline $85 \%$ & $0.285^{* * *}$ & $(0.016)$ & $0.228^{* * *}$ & $(0.019)$ \\
\hline $95 \%$ & $0.351^{* * *}$ & $(0.018)$ & $0.288^{* * *}$ & $(0.020)$ \\
\hline \multicolumn{5}{|l|}{ Doses } \\
\hline 1 & 0.000 & (.) & 0.000 & (.) \\
\hline 2 & -0.018 & $(0.011)$ & -0.024 & $(0.012)$ \\
\hline 3 & $-0.065^{* * *}$ & $(0.011)$ & $-0.048^{* * *}$ & $(0.013)$ \\
\hline \multicolumn{5}{|l|}{ Technology } \\
\hline RNA (None) & 0.000 & (.) & 0.000 & (.) \\
\hline Protein subunit (Hepatitis B) & 0.010 & $(0.014)$ & $0.067^{* * *}$ & $(0.016)$ \\
\hline Viral vector (Ebola) & 0.018 & $(0.012)$ & $0.035^{*}$ & $(0.017)$ \\
\hline Whole virus (Pertussis) & $0.052^{* * *}$ & $(0.013)$ & $0.061^{* * *}$ & $(0.017)$ \\
\hline \multicolumn{5}{|l|}{ Endorser } \\
\hline Unspecified & 0.000 & (.) & 0.000 & (.) \\
\hline Government leaders & -0.020 & $(0.016)$ & $0.042^{*}$ & $(0.021)$ \\
\hline Opposition leaders & $-0.035^{*}$ & $(0.018)$ & -0.026 & $(0.020)$ \\
\hline Leading entrepreneurs & -0.017 & $(0.017)$ & 0.003 & $(0.019)$ \\
\hline Leading entertainers & -0.017 & $(0.017)$ & -0.002 & $(0.021)$ \\
\hline Professional athletes & -0.034 & $(0.018)$ & -0.016 & $(0.019)$ \\
\hline Medical professionals & $0.084^{* * *}$ & $(0.018)$ & $0.095^{* * *}$ & $(0.020)$ \\
\hline Observations & 10830 & & 7920 & \\
\hline$R^{2}$ & 0.115 & & 0.094 & \\
\hline
\end{tabular}


Table S32 Regression results by Nationalism (25th/75th percentile split) for China.

\begin{tabular}{|c|c|c|c|c|}
\hline \multirow{3}{*}{ Developer } & \multicolumn{2}{|c|}{ Low Nationalism } & \multicolumn{2}{|c|}{ High Nationalism } \\
\hline & \multicolumn{2}{|c|}{ Vaccine Choice $(0 / 1)$} & \multicolumn{2}{|c|}{ Vaccine Choice $(0 / 1)$} \\
\hline & & & & \\
\hline Own & 0.000 & (.) & 0.000 & (.) \\
\hline Germany & $-0.099^{* * *}$ & $(0.017)$ & $-0.108^{* * *}$ & $(0.015)$ \\
\hline United States & $-0.084^{* * *}$ & $(0.018)$ & $-0.133^{* * *}$ & $(0.016)$ \\
\hline Russia & $-0.126^{* * *}$ & $(0.018)$ & $-0.135^{* * *}$ & $(0.016)$ \\
\hline India & $-0.209^{* * *}$ & $(0.020)$ & $-0.265^{* * *}$ & $(0.019)$ \\
\hline \multicolumn{5}{|l|}{ Producer } \\
\hline Own & 0.000 & (.) & 0.000 & (.) \\
\hline Germany & $-0.055^{* *}$ & $(0.018)$ & $-0.116^{* * *}$ & $(0.017)$ \\
\hline United States & $-0.097^{* * *}$ & $(0.018)$ & $-0.109^{* * *}$ & $(0.017)$ \\
\hline Russia & $-0.061^{* * *}$ & $(0.018)$ & $-0.095^{* * *}$ & $(0.018)$ \\
\hline India & $-0.121^{* * *}$ & $(0.018)$ & $-0.119^{* * *}$ & $(0.017)$ \\
\hline \multicolumn{5}{|l|}{ Duration } \\
\hline 6 months & 0.000 & (.) & 0.000 & (.) \\
\hline 1 year & $0.054^{* * *}$ & $(0.012)$ & $0.064^{* * *}$ & $(0.011)$ \\
\hline 2 years & $0.089^{* * *}$ & $(0.013)$ & $0.100^{* * *}$ & $(0.012)$ \\
\hline 5 years & $0.117^{* * *}$ & $(0.013)$ & $0.165^{* * *}$ & $(0.013)$ \\
\hline \multicolumn{5}{|l|}{ Efficacy } \\
\hline $55 \%$ & 0.000 & (.) & 0.000 & (.) \\
\hline $65 \%$ & $0.073^{* * *}$ & $(0.013)$ & $0.061^{* * *}$ & $(0.012)$ \\
\hline $75 \%$ & $0.114^{* * *}$ & $(0.015)$ & $0.143^{* * *}$ & $(0.013)$ \\
\hline $85 \%$ & $0.168^{* * *}$ & $(0.016)$ & $0.226^{* * *}$ & $(0.015)$ \\
\hline $95 \%$ & $0.238^{* * *}$ & $(0.018)$ & $0.305^{* * *}$ & $(0.017)$ \\
\hline \multicolumn{5}{|l|}{ Doses } \\
\hline 1 & 0.000 & (.) & 0.000 & (.) \\
\hline 2 & -0.006 & $(0.010)$ & 0.003 & $(0.009)$ \\
\hline 3 & 0.006 & $(0.010)$ & -0.007 & $(0.010)$ \\
\hline \multicolumn{5}{|l|}{ Technology } \\
\hline RNA (None) & 0.000 & (.) & 0.000 & (.) \\
\hline Protein subunit (Hepatitis B) & $0.033^{* *}$ & $(0.012)$ & $0.053^{* * *}$ & $(0.012)$ \\
\hline Viral vector (Ebola) & 0.023 & $(0.012)$ & $0.048^{* * *}$ & $(0.011)$ \\
\hline Whole virus (Pertussis) & $0.024^{*}$ & $(0.012)$ & $0.058^{* * *}$ & $(0.011)$ \\
\hline \multicolumn{5}{|l|}{ Endorser } \\
\hline Unspecified & 0.000 & (.) & 0.000 & (.) \\
\hline Government leaders & $0.076^{* * *}$ & $(0.015)$ & $0.075^{* * *}$ & $(0.013)$ \\
\hline Leading entrepreneurs & $0.065^{* * *}$ & $(0.016)$ & $0.072^{* * *}$ & $(0.014)$ \\
\hline Leading entertainers & $0.037^{*}$ & $(0.015)$ & $0.032^{*}$ & $(0.014)$ \\
\hline Professional athletes & 0.020 & $(0.016)$ & $0.031^{*}$ & $(0.014)$ \\
\hline Medical professionals & $0.065^{* * *}$ & $(0.017)$ & $0.041^{* *}$ & $(0.015)$ \\
\hline Observations & 14400 & & 15630 & \\
\hline$R^{2}$ & 0.068 & & 0.110 & \\
\hline
\end{tabular}

Standard errors in parentheses, ${ }^{*} p<0.05,{ }^{* *} p<0.01,{ }^{* * *} p<0.001$ 
Table S33 Regression results by Nationalism (25th/75th percentile split) for France.

\begin{tabular}{|c|c|c|c|c|}
\hline \multirow{3}{*}{ Developer } & \multicolumn{2}{|c|}{ Low Nationalism } & \multicolumn{2}{|c|}{ High Nationalism } \\
\hline & \multicolumn{2}{|c|}{ Vaccine Choice $(0 / 1)$} & \multicolumn{2}{|c|}{ Vaccine Choice $(0 / 1)$} \\
\hline & & & & \\
\hline Own & 0.000 & (.) & 0.000 & (.) \\
\hline Germany & 0.006 & $(0.033)$ & $-0.072^{*}$ & $(0.032)$ \\
\hline United States & -0.043 & $(0.033)$ & $-0.091^{* *}$ & $(0.033)$ \\
\hline Russia & $-0.092^{*}$ & $(0.036)$ & $-0.183^{* * *}$ & $(0.033)$ \\
\hline China & $-0.114^{* * *}$ & $(0.026)$ & $-0.224^{* * *}$ & $(0.026)$ \\
\hline \multicolumn{5}{|l|}{ Producer } \\
\hline Own & 0.000 & (.) & 0.000 & (.) \\
\hline Germany & -0.027 & $(0.038)$ & -0.025 & $(0.035)$ \\
\hline United States & -0.001 & $(0.039)$ & -0.047 & $(0.039)$ \\
\hline Russia & -0.025 & $(0.039)$ & -0.061 & $(0.038)$ \\
\hline China & -0.028 & $(0.025)$ & -0.039 & $(0.025)$ \\
\hline \multicolumn{5}{|l|}{ Duration } \\
\hline 6 months & 0.000 & (.) & 0.000 & (.) \\
\hline 1 year & $0.087^{* * *}$ & $(0.015)$ & $0.092^{* * *}$ & $(0.014)$ \\
\hline 2 years & $0.150^{* * *}$ & $(0.016)$ & $0.141^{* * *}$ & $(0.016)$ \\
\hline 5 years & $0.187^{* * *}$ & $(0.017)$ & $0.195^{* * *}$ & $(0.017)$ \\
\hline \multicolumn{5}{|l|}{ Efficacy } \\
\hline $55 \%$ & 0.000 & (.) & 0.000 & (.) \\
\hline $65 \%$ & $0.085^{* * *}$ & $(0.017)$ & $0.063^{* * *}$ & $(0.015)$ \\
\hline $75 \%$ & $0.182^{* * *}$ & $(0.018)$ & $0.159^{* * *}$ & $(0.016)$ \\
\hline $85 \%$ & $0.271^{* * *}$ & $(0.019)$ & $0.231^{* * *}$ & $(0.018)$ \\
\hline $95 \%$ & $0.349^{* * *}$ & $(0.021)$ & $0.306^{* * *}$ & $(0.019)$ \\
\hline \multicolumn{5}{|l|}{ Doses } \\
\hline 1 & 0.000 & (.) & 0.000 & (.) \\
\hline 2 & $-0.044^{* * *}$ & $(0.012)$ & $-0.046^{* * *}$ & $(0.012)$ \\
\hline 3 & $-0.075^{* * *}$ & $(0.014)$ & $-0.071^{* * *}$ & $(0.013)$ \\
\hline \multicolumn{5}{|l|}{ Technology } \\
\hline RNA (None) & 0.000 & (.) & 0.000 & (.) \\
\hline Protein subunit (Hepatitis B) & 0.017 & $(0.016)$ & 0.012 & $(0.016)$ \\
\hline Viral vector (Ebola) & 0.017 & $(0.017)$ & 0.025 & $(0.015)$ \\
\hline Whole virus (Pertussis) & $0.056^{* *}$ & $(0.019)$ & $0.070^{* * *}$ & $(0.017)$ \\
\hline \multicolumn{5}{|l|}{ Endorser } \\
\hline Unspecified & 0.000 & (.) & 0.000 & (.) \\
\hline Government leaders & $0.057^{* *}$ & $(0.019)$ & 0.035 & $(0.019)$ \\
\hline Opposition leaders & 0.035 & $(0.019)$ & -0.006 & $(0.019)$ \\
\hline Leading entrepreneurs & 0.024 & $(0.020)$ & 0.029 & $(0.018)$ \\
\hline Leading entertainers & 0.003 & $(0.018)$ & 0.008 & $(0.019)$ \\
\hline Professional athletes & 0.012 & $(0.020)$ & 0.015 & $(0.018)$ \\
\hline Medical professionals & $0.082^{* * *}$ & $(0.018)$ & $0.079^{* * *}$ & $(0.020)$ \\
\hline Observations & 8730 & & 9090 & \\
\hline$R^{2}$ & 0.103 & & 0.110 & \\
\hline
\end{tabular}

Standard errors in parentheses, ${ }^{*} p<0.05,{ }^{* *} p<0.01,{ }^{* * *} p<0.001$ 
Table S34 Regression results by Nationalism (25th/75th percentile split) for Germany.

\begin{tabular}{|c|c|c|c|c|}
\hline \multirow{3}{*}{ Developer } & \multicolumn{2}{|c|}{ Low Nationalism } & \multicolumn{2}{|c|}{ High Nationalism } \\
\hline & \multicolumn{2}{|c|}{ Vaccine Choice $(0 / 1)$} & \multicolumn{2}{|c|}{ Vaccine Choice $(0 / 1)$} \\
\hline & & & & \\
\hline Own & 0.000 & (.) & 0.000 & (.) \\
\hline France & -0.018 & $(0.030)$ & $-0.117^{* * *}$ & $(0.029)$ \\
\hline United States & $-0.059^{*}$ & $(0.030)$ & $-0.096^{* *}$ & $(0.029)$ \\
\hline Russia & $-0.133^{* * *}$ & $(0.033)$ & $-0.195^{* * *}$ & $(0.030)$ \\
\hline China & $-0.155^{* * *}$ & $(0.024)$ & $-0.197^{* * *}$ & $(0.024)$ \\
\hline \multicolumn{5}{|l|}{ Producer } \\
\hline Own & 0.000 & (.) & 0.000 & (.) \\
\hline France & -0.026 & $(0.035)$ & 0.042 & $(0.032)$ \\
\hline United States & 0.000 & $(0.034)$ & -0.012 & $(0.033)$ \\
\hline Russia & -0.034 & $(0.036)$ & -0.028 & $(0.031)$ \\
\hline China & -0.024 & $(0.022)$ & -0.017 & $(0.020)$ \\
\hline \multicolumn{5}{|l|}{ Duration } \\
\hline 6 months & 0.000 & (.) & 0.000 & (.) \\
\hline 1 year & $0.092^{* * *}$ & $(0.014)$ & $0.082^{* * *}$ & $(0.013)$ \\
\hline 2 years & $0.136^{* * *}$ & $(0.016)$ & $0.125^{* * *}$ & $(0.014)$ \\
\hline 5 years & $0.225^{* * *}$ & $(0.016)$ & $0.222^{* * *}$ & $(0.015)$ \\
\hline \multicolumn{5}{|l|}{ Efficacy } \\
\hline $55 \%$ & 0.000 & (.) & 0.000 & (.) \\
\hline $65 \%$ & $0.099^{* * *}$ & $(0.014)$ & $0.075^{* * *}$ & $(0.015)$ \\
\hline $75 \%$ & $0.190^{* * *}$ & $(0.017)$ & $0.161^{* * *}$ & $(0.015)$ \\
\hline $85 \%$ & $0.259^{* * *}$ & $(0.015)$ & $0.227^{* * *}$ & $(0.016)$ \\
\hline $95 \%$ & $0.350^{* * *}$ & $(0.017)$ & $0.307^{* * *}$ & $(0.017)$ \\
\hline \multicolumn{5}{|l|}{ Doses } \\
\hline 1 & 0.000 & (.) & 0.000 & (.) \\
\hline 2 & $-0.047^{* * *}$ & $(0.011)$ & $-0.028^{*}$ & $(0.011)$ \\
\hline 3 & $-0.072^{* * *}$ & $(0.013)$ & $-0.058^{* * *}$ & $(0.012)$ \\
\hline \multicolumn{5}{|l|}{ Technology } \\
\hline RNA (None) & 0.000 & (.) & 0.000 & (.) \\
\hline Protein subunit (Hepatitis B) & 0.023 & $(0.015)$ & $0.031^{*}$ & $(0.014)$ \\
\hline Viral vector (Ebola) & 0.002 & $(0.014)$ & 0.027 & $(0.014)$ \\
\hline Whole virus (Pertussis) & $0.036^{*}$ & $(0.015)$ & $0.029^{*}$ & $(0.014)$ \\
\hline \multicolumn{5}{|l|}{ Endorser } \\
\hline Unspecified & 0.000 & (.) & 0.000 & (.) \\
\hline Government leaders & 0.024 & $(0.017)$ & $0.041^{*}$ & $(0.019)$ \\
\hline Opposition leaders & 0.019 & $(0.017)$ & $0.045^{* *}$ & $(0.017)$ \\
\hline Leading entrepreneurs & 0.011 & $(0.018)$ & $0.064^{* * *}$ & $(0.017)$ \\
\hline Leading entertainers & 0.003 & $(0.018)$ & $0.045^{* *}$ & $(0.017)$ \\
\hline Professional athletes & -0.014 & $(0.016)$ & $0.042^{*}$ & $(0.017)$ \\
\hline Medical professionals & $0.035^{*}$ & $(0.017)$ & $0.080^{* * *}$ & $(0.017)$ \\
\hline Observations & 10260 & & 10980 & \\
\hline$R^{2}$ & 0.110 & & 0.104 & \\
\hline
\end{tabular}

Standard errors in parentheses, ${ }^{*} p<0.05,{ }^{* *} p<0.01,{ }^{* * *} p<0.001$ 
Table S35 Regression results by Nationalism (25th/75th percentile split) for Hong Kong.

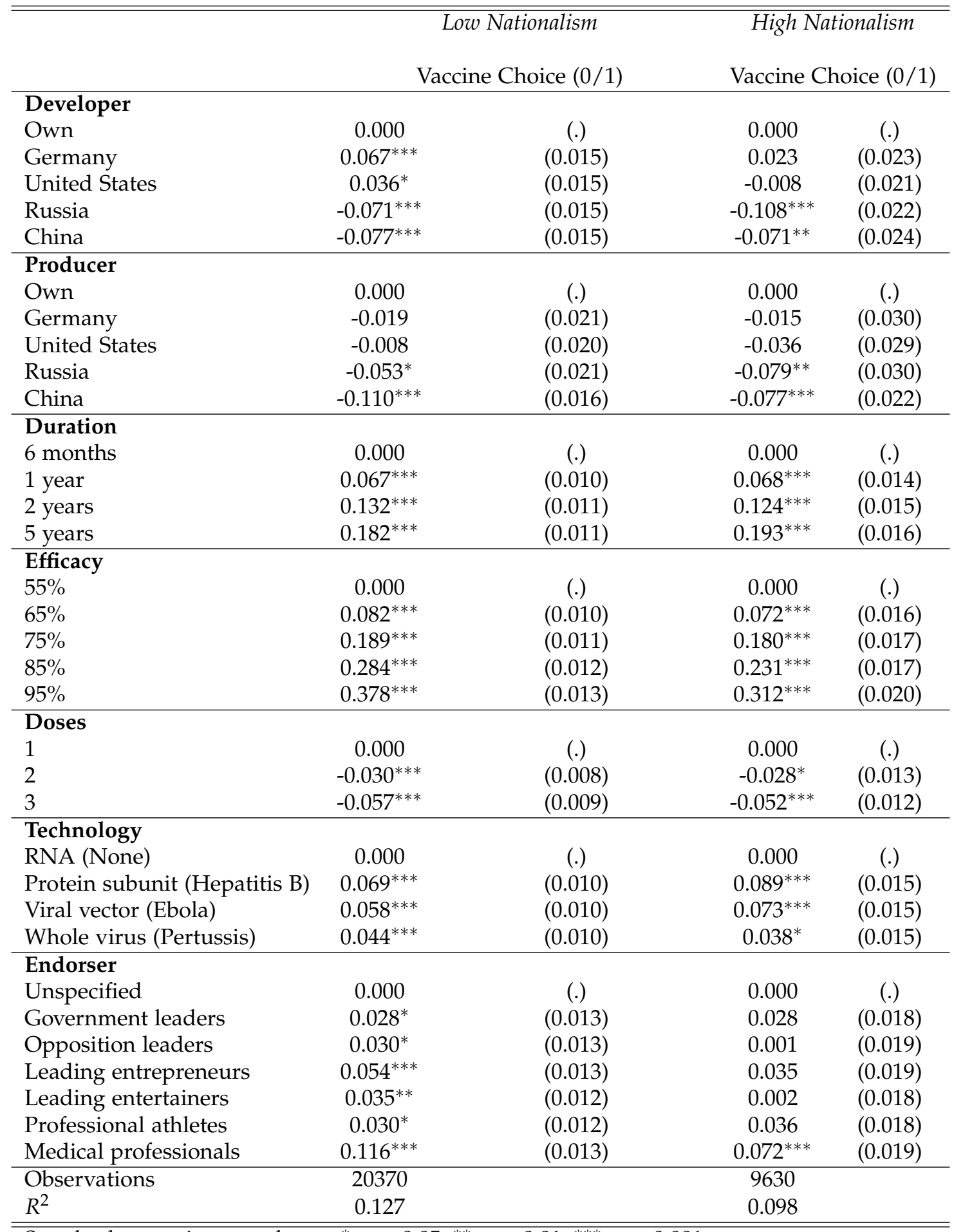

Standard errors in parentheses, ${ }^{*} p<0.05,{ }^{* *} p<0.01,{ }^{* * *} p<0.001$ 
Table S36 Regression results by Nationalism (25th/75th percentile split) for Japan.

\begin{tabular}{|c|c|c|c|c|}
\hline \multirow{3}{*}{ Developer } & \multicolumn{2}{|c|}{ Low Nationalism } & \multicolumn{2}{|c|}{ High Nationalism } \\
\hline & \multicolumn{2}{|c|}{ Vaccine Choice $(0 / 1)$} & \multicolumn{2}{|c|}{ Vaccine Choice $(0 / 1)$} \\
\hline & & & & \\
\hline Own & 0.000 & (.) & 0.000 & (.) \\
\hline Germany & $-0.106^{* * *}$ & $(0.017)$ & $-0.173^{* * *}$ & $(0.018)$ \\
\hline United States & $-0.108^{* * *}$ & $(0.018)$ & $-0.157^{* * *}$ & $(0.018)$ \\
\hline Russia & $-0.238^{* * *}$ & $(0.018)$ & $-0.322^{* * *}$ & $(0.017)$ \\
\hline China & $-0.309^{* * *}$ & $(0.018)$ & $-0.375^{* * *}$ & $(0.018)$ \\
\hline \multicolumn{5}{|l|}{ Producer } \\
\hline Own & 0.000 & (.) & 0.000 & (.) \\
\hline Germany & $-0.047^{*}$ & $(0.022)$ & -0.024 & $(0.022)$ \\
\hline United States & -0.020 & $(0.023)$ & -0.023 & $(0.023)$ \\
\hline Russia & $-0.110^{* * *}$ & $(0.022)$ & $-0.099^{* * *}$ & $(0.021)$ \\
\hline China & $-0.186^{* * *}$ & $(0.016)$ & $-0.194^{* * *}$ & $(0.016)$ \\
\hline \multicolumn{5}{|l|}{ Duration } \\
\hline 6 months & 0.000 & (.) & 0.000 & (.) \\
\hline 1 year & $0.054^{* * *}$ & $(0.011)$ & $0.046^{* * *}$ & $(0.010)$ \\
\hline 2 years & $0.085^{* * *}$ & $(0.012)$ & $0.082^{* * *}$ & $(0.011)$ \\
\hline 5 years & $0.140^{* * *}$ & $(0.012)$ & $0.117^{* * *}$ & $(0.012)$ \\
\hline \multicolumn{5}{|l|}{ Efficacy } \\
\hline $55 \%$ & 0.000 & (.) & 0.000 & (.) \\
\hline $65 \%$ & $0.080^{* * *}$ & $(0.013)$ & $0.050^{* * *}$ & $(0.011)$ \\
\hline $75 \%$ & $0.121^{* * *}$ & $(0.014)$ & $0.108^{* * *}$ & $(0.013)$ \\
\hline $85 \%$ & $0.197^{* * *}$ & $(0.015)$ & $0.196^{* * *}$ & $(0.014)$ \\
\hline $95 \%$ & $0.254^{* * *}$ & $(0.015)$ & $0.237^{* * *}$ & $(0.015)$ \\
\hline \multicolumn{5}{|l|}{ Doses } \\
\hline 1 & 0.000 & (.) & 0.000 & (.) \\
\hline 2 & -0.019 & $(0.010)$ & -0.009 & $(0.009)$ \\
\hline 3 & $-0.027^{* *}$ & $(0.010)$ & $-0.038^{* * *}$ & $(0.010)$ \\
\hline \multicolumn{5}{|l|}{ Technology } \\
\hline RNA (None) & 0.000 & (.) & 0.000 & (.) \\
\hline Protein subunit (Hepatitis B) & $0.052^{* * *}$ & $(0.013)$ & $0.046^{* * *}$ & $(0.011)$ \\
\hline Viral vector (Ebola) & $0.078^{* * *}$ & $(0.012)$ & $0.051^{* * *}$ & $(0.011)$ \\
\hline Whole virus (Pertussis) & $0.057^{* * *}$ & $(0.013)$ & $0.068^{* * *}$ & $(0.011)$ \\
\hline \multicolumn{5}{|l|}{ Endorser } \\
\hline Unspecified & 0.000 & (.) & 0.000 & (.) \\
\hline Government leaders & $0.043^{* *}$ & $(0.015)$ & 0.024 & $(0.014)$ \\
\hline Opposition leaders & 0.026 & $(0.015)$ & $0.030^{*}$ & $(0.014)$ \\
\hline Leading entrepreneurs & 0.011 & $(0.015)$ & 0.026 & $(0.014)$ \\
\hline Leading entertainers & 0.008 & $(0.015)$ & 0.019 & $(0.013)$ \\
\hline Professional athletes & 0.029 & $(0.015)$ & $0.032^{*}$ & $(0.013)$ \\
\hline Medical professionals & $0.074^{* * *}$ & $(0.015)$ & $0.072^{* * *}$ & $(0.015)$ \\
\hline Observations & 14730 & & 15270 & \\
\hline$R^{2}$ & 0.136 & & 0.165 & \\
\hline
\end{tabular}

Standard errors in parentheses, ${ }^{*} p<0.05,{ }^{* *} p<0.01,{ }^{* * *} p<0.001$ 
Table S37 Regression results by Nationalism (25th/75th percentile split) for Mexico.

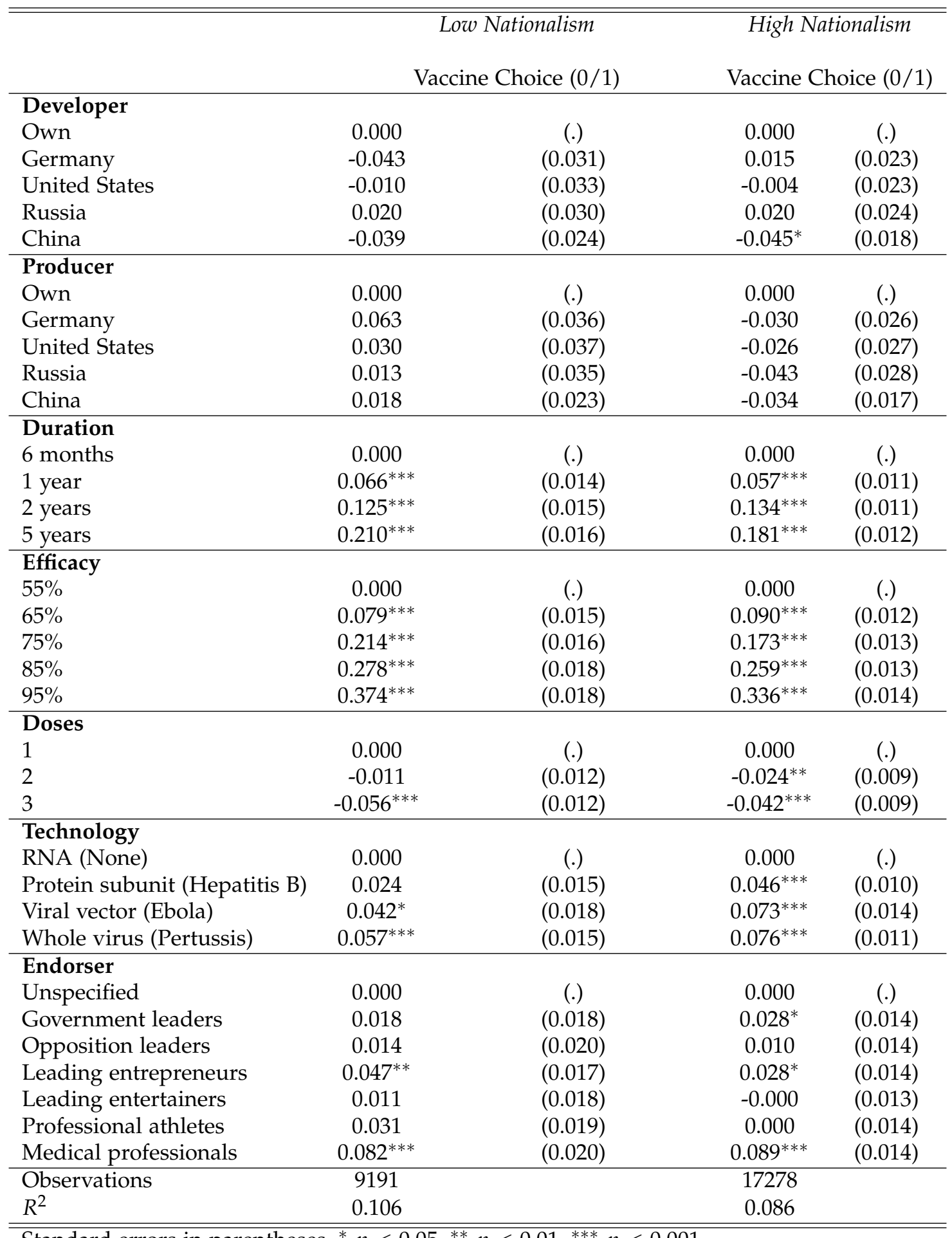


Table S38 Regression results by Nationalism (25th/75th percentile split) for Philippines.

\begin{tabular}{|c|c|c|c|c|}
\hline \multirow{3}{*}{ Developer } & \multicolumn{2}{|c|}{ Low Nationalism } & \multicolumn{2}{|c|}{ High Nationalism } \\
\hline & \multicolumn{2}{|c|}{ Vaccine Choice $(0 / 1)$} & \multicolumn{2}{|c|}{ Vaccine Choice $(0 / 1)$} \\
\hline & & & & \\
\hline Own & 0.000 & (.) & 0.000 & (.) \\
\hline Germany & 0.013 & $(0.018)$ & 0.001 & $(0.017)$ \\
\hline United States & $0.042^{*}$ & $(0.018)$ & $0.036^{*}$ & $(0.017)$ \\
\hline Russia & 0.005 & $(0.017)$ & -0.016 & $(0.017)$ \\
\hline China & $-0.065^{* * *}$ & $(0.018)$ & $-0.064^{* * *}$ & $(0.016)$ \\
\hline \multicolumn{5}{|l|}{ Producer } \\
\hline Own & 0.000 & (.) & 0.000 & (.) \\
\hline Germany & 0.025 & $(0.024)$ & -0.030 & $(0.023)$ \\
\hline United States & 0.010 & $(0.024)$ & -0.015 & $(0.023)$ \\
\hline Russia & -0.032 & $(0.023)$ & -0.025 & $(0.022)$ \\
\hline China & $-0.066^{* * *}$ & $(0.017)$ & $-0.070^{* * *}$ & $(0.016)$ \\
\hline \multicolumn{5}{|l|}{ Duration } \\
\hline 6 months & 0.000 & (.) & 0.000 & (.) \\
\hline 1 year & $0.112^{* * *}$ & $(0.012)$ & $0.065^{* * *}$ & $(0.011)$ \\
\hline 2 years & $0.162^{* * *}$ & $(0.013)$ & $0.126^{* * *}$ & $(0.012)$ \\
\hline 5 years & $0.256^{* * *}$ & $(0.014)$ & $0.196^{* * *}$ & $(0.012)$ \\
\hline \multicolumn{5}{|l|}{ Efficacy } \\
\hline $55 \%$ & 0.000 & (.) & 0.000 & (.) \\
\hline $65 \%$ & $0.073^{* * *}$ & $(0.012)$ & $0.072^{* * *}$ & $(0.012)$ \\
\hline $75 \%$ & $0.190^{* * *}$ & $(0.014)$ & $0.162^{* * *}$ & $(0.013)$ \\
\hline $85 \%$ & $0.284^{* * *}$ & $(0.014)$ & $0.251^{* * *}$ & $(0.014)$ \\
\hline $95 \%$ & $0.397^{* * *}$ & $(0.015)$ & $0.335^{* * *}$ & $(0.015)$ \\
\hline \multicolumn{5}{|l|}{ Doses } \\
\hline 1 & 0.000 & (.) & 0.000 & (.) \\
\hline 2 & $-0.036^{* * *}$ & $(0.010)$ & -0.007 & $(0.009)$ \\
\hline 3 & $-0.050^{* * *}$ & $(0.011)$ & $-0.020^{*}$ & $(0.009)$ \\
\hline \multicolumn{5}{|l|}{ Technology } \\
\hline RNA (None) & 0.000 & (.) & 0.000 & (.) \\
\hline Protein subunit (Hepatitis B) & $0.063^{* * *}$ & $(0.012)$ & $0.062^{* * *}$ & $(0.011)$ \\
\hline Viral vector (Ebola) & $0.055^{* * *}$ & $(0.012)$ & $0.073^{* * *}$ & $(0.011)$ \\
\hline Whole virus (Pertussis) & $0.086^{* * *}$ & $(0.013)$ & $0.085^{* * *}$ & $(0.011)$ \\
\hline \multicolumn{5}{|l|}{ Endorser } \\
\hline Unspecified & 0.000 & (.) & 0.000 & (.) \\
\hline Government leaders & $0.064^{* * *}$ & $(0.017)$ & $0.065^{* * *}$ & $(0.014)$ \\
\hline Opposition leaders & 0.003 & $(0.016)$ & 0.011 & $(0.015)$ \\
\hline Leading entrepreneurs & $0.054^{* * *}$ & $(0.015)$ & $0.056^{* * *}$ & $(0.014)$ \\
\hline Leading entertainers & 0.027 & $(0.015)$ & 0.024 & $(0.014)$ \\
\hline Professional athletes & $0.074^{* * *}$ & $(0.015)$ & $0.070^{* * *}$ & $(0.015)$ \\
\hline Medical professionals & $0.169^{* * *}$ & $(0.016)$ & $0.133^{* * *}$ & $(0.015)$ \\
\hline Observations & 13230 & & 16770 & \\
\hline$R^{2}$ & 0.146 & & 0.098 & \\
\hline
\end{tabular}

Standard errors in parentheses, ${ }^{*} p<0.05,{ }^{* *} p<0.01,{ }^{* * *} p<0.001$ 
Table S39 Regression results by Nationalism (25th/75th percentile split) for South Korea.

\begin{tabular}{|c|c|c|c|c|}
\hline \multirow{3}{*}{ Developer } & \multicolumn{2}{|c|}{ Low Nationalism } & \multicolumn{2}{|c|}{ High Nationalism } \\
\hline & \multicolumn{2}{|c|}{ Vaccine Choice $(0 / 1)$} & \multicolumn{2}{|c|}{ Vaccine Choice $(0 / 1)$} \\
\hline & & & & \\
\hline Own & 0.000 & (.) & 0.000 & (.) \\
\hline Germany & -0.023 & $(0.023)$ & $-0.064^{* * *}$ & $(0.015)$ \\
\hline United States & -0.001 & $(0.022)$ & $-0.049^{* * *}$ & $(0.014)$ \\
\hline Russia & $-0.142^{* * *}$ & $(0.023)$ & $-0.192^{* * *}$ & $(0.015)$ \\
\hline China & $-0.254^{* * *}$ & $(0.021)$ & $-0.283^{* * *}$ & $(0.015)$ \\
\hline \multicolumn{5}{|l|}{ Producer } \\
\hline Own & 0.000 & (.) & 0.000 & (.) \\
\hline Germany & $0.060^{*}$ & $(0.028)$ & -0.032 & $(0.020)$ \\
\hline United States & $0.067^{*}$ & $(0.028)$ & $-0.041^{*}$ & $(0.019)$ \\
\hline Russia & -0.013 & $(0.029)$ & $-0.078^{* * *}$ & $(0.020)$ \\
\hline China & $-0.115^{* * *}$ & $(0.021)$ & $-0.163^{* * *}$ & $(0.014)$ \\
\hline \multicolumn{5}{|l|}{ Duration } \\
\hline 6 months & 0.000 & (.) & 0.000 & (.) \\
\hline 1 year & $0.054^{* * *}$ & $(0.014)$ & $0.079^{* * *}$ & $(0.009)$ \\
\hline 2 years & $0.100^{* * *}$ & $(0.014)$ & $0.137^{* * *}$ & $(0.010)$ \\
\hline 5 years & $0.169^{* * *}$ & $(0.015)$ & $0.184^{* * *}$ & $(0.011)$ \\
\hline \multicolumn{5}{|l|}{ Efficacy } \\
\hline $55 \%$ & 0.000 & (.) & 0.000 & (.) \\
\hline $65 \%$ & $0.113^{* * *}$ & $(0.016)$ & $0.094^{* * *}$ & $(0.010)$ \\
\hline $75 \%$ & $0.173^{* * *}$ & $(0.016)$ & $0.194^{* * *}$ & $(0.011)$ \\
\hline $85 \%$ & $0.279^{* * *}$ & $(0.018)$ & $0.284^{* * *}$ & $(0.012)$ \\
\hline $95 \%$ & $0.349^{* * *}$ & $(0.019)$ & $0.383^{* * *}$ & $(0.012)$ \\
\hline \multicolumn{5}{|l|}{ Doses } \\
\hline 1 & 0.000 & (.) & 0.000 & (.) \\
\hline 2 & $-0.026^{*}$ & $(0.011)$ & $-0.033^{* * *}$ & $(0.008)$ \\
\hline 3 & $-0.043^{* * *}$ & $(0.012)$ & $-0.058^{* * *}$ & $(0.008)$ \\
\hline \multicolumn{5}{|l|}{ Technology } \\
\hline RNA (None) & 0.000 & (.) & 0.000 & (.) \\
\hline Protein subunit (Hepatitis B) & 0.029 & $(0.015)$ & $0.037^{* * *}$ & $(0.010)$ \\
\hline Viral vector (Ebola) & $0.050^{* * *}$ & $(0.015)$ & $0.037^{* * *}$ & $(0.009)$ \\
\hline Whole virus (Pertussis) & $0.049^{* *}$ & $(0.015)$ & $0.043^{* * *}$ & $(0.009)$ \\
\hline \multicolumn{5}{|l|}{ Endorser } \\
\hline Unspecified & 0.000 & (.) & 0.000 & (.) \\
\hline Government leaders & $0.070^{* * *}$ & $(0.018)$ & $0.037^{* *}$ & $(0.012)$ \\
\hline Opposition leaders & 0.028 & $(0.019)$ & 0.019 & $(0.012)$ \\
\hline Leading entrepreneurs & 0.025 & $(0.018)$ & $0.040^{* * *}$ & $(0.012)$ \\
\hline Leading entertainers & 0.029 & $(0.018)$ & 0.022 & $(0.012)$ \\
\hline Professional athletes & 0.020 & $(0.019)$ & $0.025^{*}$ & $(0.012)$ \\
\hline Medical professionals & $0.078^{* * *}$ & $(0.018)$ & $0.083^{* * *}$ & $(0.012)$ \\
\hline Observations & 9570 & & 20430 & \\
\hline$R^{2}$ & 0.152 & & 0.165 & \\
\hline
\end{tabular}

Standard errors in parentheses, ${ }^{*} p<0.05,{ }^{* *} p<0.01,{ }^{* * *} p<0.001$ 
Table S40 Regression results by Nationalism (25th/75th percentile split) for Singapore.

\begin{tabular}{|c|c|c|c|c|}
\hline \multirow[b]{2}{*}{ Developer } & \multicolumn{2}{|c|}{ Low Nationalism } & \multicolumn{2}{|c|}{ High Nationalism } \\
\hline & & & & \\
\hline Own & 0.000 & (.) & 0.000 & (.) \\
\hline Germany & $-0.059^{* * *}$ & $(0.014)$ & $-0.121^{* * *}$ & $(0.025)$ \\
\hline United States & $-0.073^{* * *}$ & $(0.014)$ & $-0.084^{* *}$ & $(0.026)$ \\
\hline Russia & $-0.156^{* * *}$ & $(0.014)$ & $-0.197^{* * *}$ & $(0.026)$ \\
\hline China & $-0.124^{* * *}$ & $(0.013)$ & $-0.137^{* * *}$ & $(0.026)$ \\
\hline \multicolumn{5}{|l|}{ Producer } \\
\hline Own & 0.000 & (.) & 0.000 & (.) \\
\hline Germany & $-0.039 *$ & $(0.019)$ & 0.027 & $(0.033)$ \\
\hline United States & -0.019 & $(0.018)$ & -0.052 & $(0.033)$ \\
\hline Russia & $-0.071^{* * *}$ & $(0.018)$ & $-0.075^{*}$ & $(0.032)$ \\
\hline China & $-0.075^{* * *}$ & $(0.014)$ & $-0.076^{* *}$ & $(0.023)$ \\
\hline \multicolumn{5}{|l|}{ Duration } \\
\hline 6 months & 0.000 & (.) & 0.000 & (.) \\
\hline 1 year & $0.064^{* * *}$ & $(0.009)$ & $0.085^{* * *}$ & $(0.016)$ \\
\hline 2 years & $0.127^{* * *}$ & $(0.010)$ & $0.155^{* * *}$ & $(0.018)$ \\
\hline 5 years & $0.178^{* * *}$ & $(0.010)$ & $0.207^{* * *}$ & $(0.019)$ \\
\hline \multicolumn{5}{|l|}{ Efficacy } \\
\hline $55 \%$ & 0.000 & (.) & 0.000 & (.) \\
\hline $65 \%$ & $0.119^{* * *}$ & $(0.010)$ & $0.107^{* * *}$ & $(0.018)$ \\
\hline $75 \%$ & $0.226^{* * *}$ & $(0.011)$ & $0.199^{* * *}$ & $(0.018)$ \\
\hline $85 \%$ & $0.307^{* * *}$ & $(0.012)$ & $0.265^{* * *}$ & $(0.020)$ \\
\hline $95 \%$ & $0.413^{* * *}$ & $(0.013)$ & $0.363^{* * *}$ & $(0.022)$ \\
\hline \multicolumn{5}{|l|}{ Doses } \\
\hline 1 & 0.000 & (.) & 0.000 & (.) \\
\hline 2 & $-0.021^{*}$ & $(0.008)$ & $-0.030^{*}$ & $(0.013)$ \\
\hline 3 & $-0.055^{* * *}$ & $(0.009)$ & $-0.055^{* * *}$ & $(0.015)$ \\
\hline \multicolumn{5}{|l|}{ Technology } \\
\hline RNA (None) & 0.000 & (.) & 0.000 & (.) \\
\hline Protein subunit (Hepatitis B) & $0.029^{* *}$ & $(0.010)$ & $0.066^{* * *}$ & $(0.016)$ \\
\hline Viral vector (Ebola) & $0.033^{* * *}$ & $(0.009)$ & $0.048^{* *}$ & $(0.017)$ \\
\hline Whole virus (Pertussis) & $0.036^{* * *}$ & $(0.010)$ & $0.046^{* *}$ & $(0.017)$ \\
\hline \multicolumn{5}{|l|}{ Endorser } \\
\hline Unspecified & 0.000 & (.) & 0.000 & (.) \\
\hline Government leaders & $0.081^{* * *}$ & $(0.013)$ & $0.075^{* * *}$ & $(0.022)$ \\
\hline Opposition leaders & -0.000 & $(0.012)$ & 0.021 & $(0.020)$ \\
\hline Leading entrepreneurs & 0.016 & $(0.012)$ & 0.012 & $(0.021)$ \\
\hline Leading entertainers & 0.004 & $(0.012)$ & 0.007 & $(0.020)$ \\
\hline Professional athletes & 0.021 & $(0.013)$ & $0.059^{* *}$ & $(0.021)$ \\
\hline Medical professionals & $0.110^{* * *}$ & $(0.013)$ & $0.072^{* * *}$ & $(0.022)$ \\
\hline Observations & 22410 & & 7590 & \\
\hline$R^{2}$ & 0.130 & & 0.125 & \\
\hline
\end{tabular}

Standard errors in parentheses, ${ }^{*} p<0.05,{ }^{* *} p<0.01,{ }^{* * *} p<0.001$ 
Table S41 Regression results by Nationalism (25th/75th percentile split) for Spain.

\begin{tabular}{|c|c|c|c|c|}
\hline \multirow{3}{*}{$\begin{array}{l}\text { Developer } \\
\end{array}$} & \multicolumn{2}{|c|}{ Low Nationalism } & \multicolumn{2}{|c|}{ High Nationalism } \\
\hline & \multicolumn{2}{|c|}{ Vaccine Choice $(0 / 1)$} & \multicolumn{2}{|c|}{ Vaccine Choice $(0 / 1)$} \\
\hline & & & & \\
\hline Own & 0.000 & (.) & 0.000 & (.) \\
\hline Germany & -0.035 & $(0.020)$ & -0.021 & $(0.025)$ \\
\hline United States & $-0.044^{*}$ & $(0.021)$ & -0.030 & $(0.024)$ \\
\hline Russia & $-0.067^{* *}$ & $(0.021)$ & $-0.083^{* * *}$ & $(0.023)$ \\
\hline China & $-0.091^{* * *}$ & $(0.016)$ & $-0.098^{* * *}$ & $(0.019)$ \\
\hline \multicolumn{5}{|l|}{ Producer } \\
\hline Own & 0.000 & (.) & 0.000 & (.) \\
\hline Germany & -0.008 & $(0.023)$ & 0.001 & $(0.028)$ \\
\hline United States & -0.034 & $(0.024)$ & -0.046 & $(0.028)$ \\
\hline Russia & $-0.049^{*}$ & $(0.024)$ & -0.027 & $(0.027)$ \\
\hline China & $-0.039^{* *}$ & $(0.015)$ & -0.030 & $(0.018)$ \\
\hline \multicolumn{5}{|l|}{ Duration } \\
\hline 6 months & 0.000 & (.) & 0.000 & (.) \\
\hline 1 year & $0.080^{* * *}$ & $(0.010)$ & $0.083^{* * *}$ & $(0.012)$ \\
\hline 2 years & $0.137^{* * *}$ & $(0.010)$ & $0.154^{* * *}$ & $(0.012)$ \\
\hline 5 years & $0.215^{* * *}$ & $(0.011)$ & $0.240^{* * *}$ & $(0.013)$ \\
\hline \multicolumn{5}{|l|}{ Efficacy } \\
\hline $55 \%$ & 0.000 & (.) & 0.000 & (.) \\
\hline $65 \%$ & $0.095^{* * *}$ & $(0.010)$ & $0.113^{* * *}$ & $(0.013)$ \\
\hline $75 \%$ & $0.204^{* * *}$ & $(0.011)$ & $0.208^{* * *}$ & $(0.014)$ \\
\hline $85 \%$ & $0.298^{* * *}$ & $(0.012)$ & $0.314^{* * *}$ & $(0.014)$ \\
\hline $95 \%$ & $0.400^{* * *}$ & $(0.013)$ & $0.392^{* * *}$ & $(0.015)$ \\
\hline \multicolumn{5}{|l|}{ Doses } \\
\hline 1 & 0.000 & (.) & 0.000 & (.) \\
\hline 2 & $-0.022^{*}$ & $(0.009)$ & $-0.044^{* * *}$ & $(0.010)$ \\
\hline 3 & $-0.048^{* * *}$ & $(0.008)$ & $-0.069^{* * *}$ & $(0.010)$ \\
\hline \multicolumn{5}{|l|}{ Technology } \\
\hline RNA (None) & 0.000 & (.) & 0.000 & (.) \\
\hline Protein subunit (Hepatitis B) & $0.046^{* * *}$ & $(0.009)$ & $0.043^{* * *}$ & $(0.010)$ \\
\hline Viral vector (Ebola) & $0.066^{* * *}$ & $(0.013)$ & $0.041^{* *}$ & $(0.014)$ \\
\hline Whole virus (Pertussis) & $0.070^{* * *}$ & $(0.010)$ & $0.057^{* * *}$ & $(0.011)$ \\
\hline \multicolumn{5}{|l|}{ Endorser } \\
\hline Unspecified & 0.000 & (.) & 0.000 & (.) \\
\hline Government leaders & -0.006 & $(0.013)$ & -0.015 & $(0.014)$ \\
\hline Opposition leaders & 0.011 & $(0.012)$ & -0.023 & $(0.014)$ \\
\hline Leading entrepreneurs & 0.022 & $(0.012)$ & 0.007 & $(0.014)$ \\
\hline Leading entertainers & -0.016 & $(0.012)$ & $-0.044^{* *}$ & $(0.014)$ \\
\hline Professional athletes & 0.013 & $(0.012)$ & -0.026 & $(0.015)$ \\
\hline Medical professionals & $0.105^{* * *}$ & $(0.013)$ & $0.073^{* * *}$ & $(0.015)$ \\
\hline Observations & 19960 & & 15284 & \\
\hline$R^{2}$ & 0.125 & & 0.128 & \\
\hline
\end{tabular}

Standard errors in parentheses, ${ }^{*} p<0.05,{ }^{* *} p<0.01,{ }^{* * *} p<0.001$ 
Table S42 Regression results by Nationalism (25th/75th percentile split) for Taiwan.

\begin{tabular}{|c|c|c|c|c|}
\hline \multirow{3}{*}{ Developer } & \multicolumn{2}{|c|}{ Low Nationalism } & \multicolumn{2}{|c|}{ High Nationalism } \\
\hline & \multicolumn{2}{|c|}{ Vaccine Choice $(0 / 1)$} & \multicolumn{2}{|c|}{ Vaccine Choice $(0 / 1)$} \\
\hline & & & & \\
\hline Own & 0.000 & (.) & 0.000 & (.) \\
\hline Germany & -0.006 & $(0.021)$ & $-0.071^{* * *}$ & $(0.014)$ \\
\hline United States & -0.018 & $(0.020)$ & $-0.059^{* * *}$ & $(0.014)$ \\
\hline Russia & $-0.099^{* * *}$ & $(0.021)$ & $-0.164^{* * *}$ & $(0.014)$ \\
\hline China & $-0.181^{* * *}$ & $(0.022)$ & $-0.227^{* * *}$ & $(0.014)$ \\
\hline \multicolumn{5}{|l|}{ Producer } \\
\hline Own & 0.000 & (.) & 0.000 & (.) \\
\hline Germany & 0.005 & $(0.027)$ & 0.019 & $(0.018)$ \\
\hline United States & -0.016 & $(0.025)$ & -0.021 & $(0.018)$ \\
\hline Russia & -0.048 & $(0.027)$ & $-0.054^{* *}$ & $(0.017)$ \\
\hline China & $-0.185^{* * *}$ & $(0.021)$ & $-0.226^{* * *}$ & $(0.013)$ \\
\hline \multicolumn{5}{|l|}{ Duration } \\
\hline 6 months & 0.000 & (.) & 0.000 & (.) \\
\hline 1 year & $0.048^{* * *}$ & $(0.013)$ & $0.038^{* * *}$ & $(0.008)$ \\
\hline 2 years & $0.083^{* * *}$ & $(0.013)$ & $0.083^{* * *}$ & $(0.009)$ \\
\hline 5 years & $0.121^{* * *}$ & $(0.014)$ & $0.123^{* * *}$ & $(0.010)$ \\
\hline \multicolumn{5}{|l|}{ Efficacy } \\
\hline $55 \%$ & 0.000 & (.) & 0.000 & (.) \\
\hline $65 \%$ & $0.091^{* * *}$ & $(0.014)$ & $0.072^{* * *}$ & $(0.010)$ \\
\hline $75 \%$ & $0.179^{* * *}$ & $(0.015)$ & $0.155^{* * *}$ & $(0.010)$ \\
\hline $85 \%$ & $0.269^{* * *}$ & $(0.016)$ & $0.235^{* * *}$ & $(0.011)$ \\
\hline $95 \%$ & $0.336^{* * *}$ & $(0.018)$ & $0.307^{* * *}$ & $(0.012)$ \\
\hline \multicolumn{5}{|l|}{ Doses } \\
\hline 1 & 0.000 & (.) & 0.000 & (.) \\
\hline 2 & $-0.026^{*}$ & $(0.012)$ & $-0.027^{* * *}$ & $(0.008)$ \\
\hline 3 & $-0.032^{* *}$ & $(0.012)$ & $-0.037^{* * *}$ & $(0.007)$ \\
\hline \multicolumn{5}{|l|}{ Technology } \\
\hline RNA (None) & 0.000 & (.) & 0.000 & (.) \\
\hline Protein subunit (Hepatitis B) & $0.083^{* * *}$ & $(0.015)$ & $0.056^{* * *}$ & $(0.009)$ \\
\hline Viral vector (Ebola) & $0.090^{* * *}$ & $(0.015)$ & $0.069^{* * *}$ & $(0.009)$ \\
\hline Whole virus (Pertussis) & $0.053^{* * *}$ & $(0.014)$ & $0.043^{* * *}$ & $(0.009)$ \\
\hline \multicolumn{5}{|l|}{ Endorser } \\
\hline Unspecified & 0.000 & (.) & 0.000 & (.) \\
\hline Government leaders & $0.037^{*}$ & $(0.017)$ & $0.050^{* * *}$ & $(0.011)$ \\
\hline Opposition leaders & $0.037^{*}$ & $(0.017)$ & $0.035^{* *}$ & $(0.012)$ \\
\hline Leading entrepreneurs & $0.054^{* *}$ & $(0.017)$ & $0.056^{* * *}$ & $(0.011)$ \\
\hline Leading entertainers & 0.010 & $(0.016)$ & $0.024^{*}$ & $(0.011)$ \\
\hline Professional athletes & 0.018 & $(0.016)$ & $0.032^{* *}$ & $(0.011)$ \\
\hline Medical professionals & $0.113^{* * *}$ & $(0.018)$ & $0.093^{* * *}$ & $(0.012)$ \\
\hline Observations & 11160 & & 24900 & \\
\hline$R^{2}$ & 0.133 & & 0.147 & \\
\hline
\end{tabular}

Standard errors in parentheses, ${ }^{*} p<0.05,{ }^{* *} p<0.01,{ }^{* * *} p<0.001$ 
Table S43 Regression results by Nationalism (25th/75th percentile split) for United Kingdom.

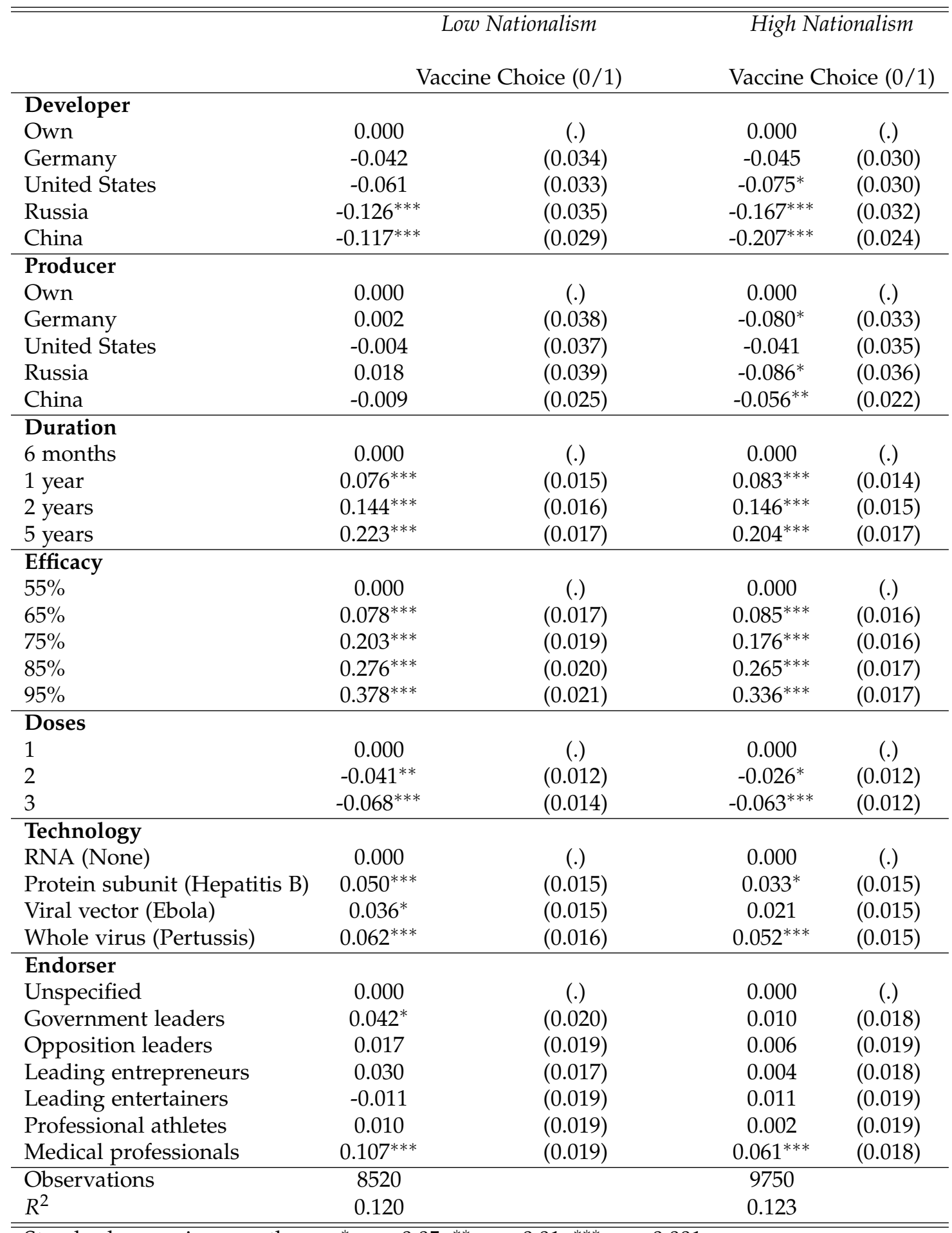

Standard errors in parentheses, ${ }^{*} p<0.05,{ }^{* *} p<0.01,{ }^{* * *} p<0.001$ 
Table S44 Regression results by Nationalism (25th/75th percentile split) for United States.

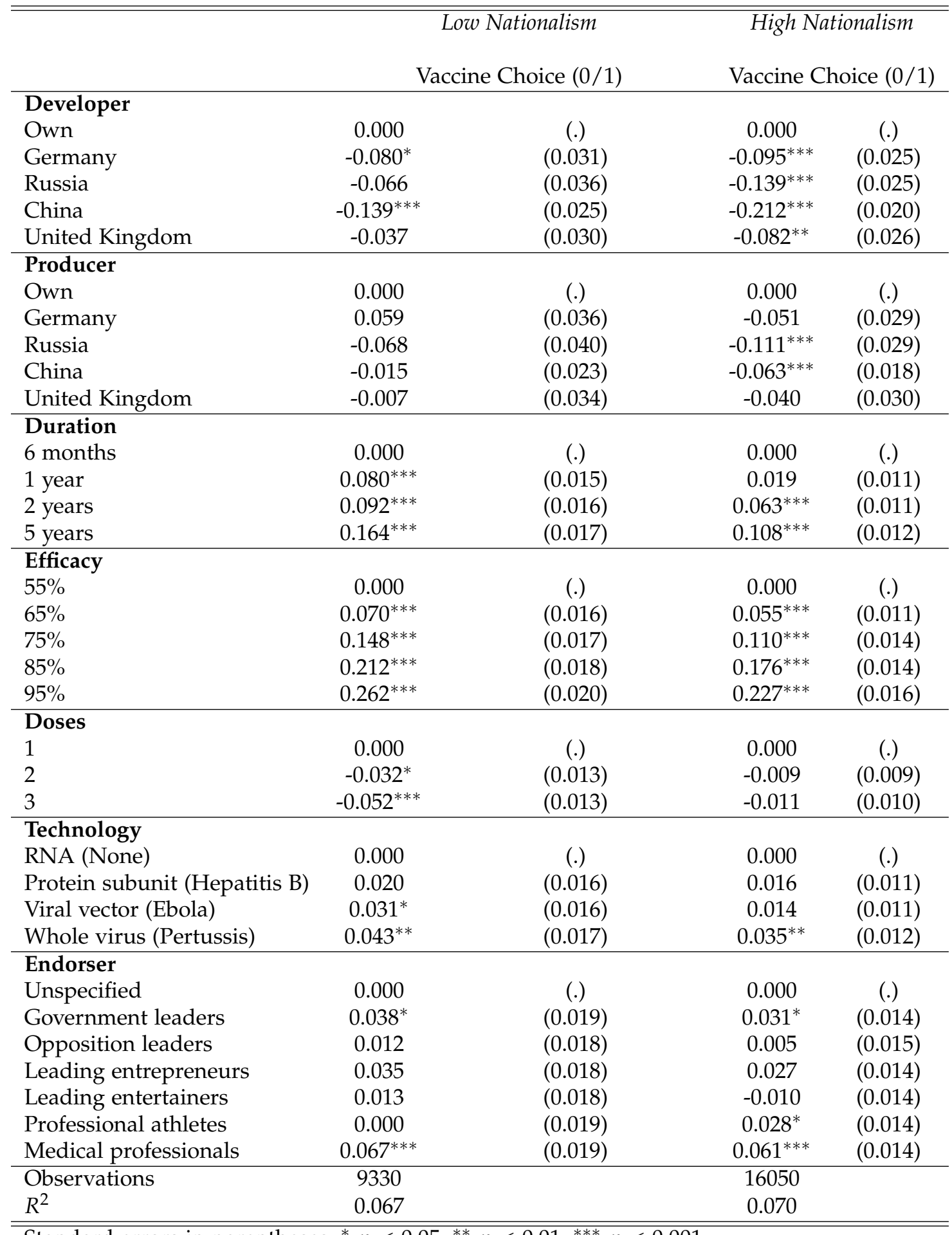

Standard errors in parentheses, ${ }^{*} p<0.05,{ }^{* *} p<0.01,{ }^{* * *} p<0.001$ 